NASA/TM-2005-213653

\title{
Collection Efficiency and Ice Accretion Characteristics of Two Full Scale and One 1/4 Scale Business Jet Horizontal Tails
}

Colin S. Bidwell

Glenn Research Center, Cleveland, Ohio

Michael Papadakis

Wichita State University, Wichita, Kansas 
Since its founding, NASA has been dedicated to the advancement of aeronautics and space science. The NASA Scientific and Technical Information (STI) Program Office plays a key part in helping NASA maintain this important role.

The NASA STI Program Office is operated by Langley Research Center, the Lead Center for NASA's scientific and technical information. The NASA STI Program Office provides access to the NASA STI Database, the largest collection of aeronautical and space science STI in the world. The Program Office is also NASA's institutional mechanism for disseminating the results of its research and development activities. These results are published by NASA in the NASA STI Report Series, which includes the following report types:

- TECHNICAL PUBLICATION. Reports of completed research or a major significant phase of research that present the results of NASA programs and include extensive data or theoretical analysis. Includes compilations of significant scientific and technical data and information deemed to be of continuing reference value. NASA's counterpart of peerreviewed formal professional papers but has less stringent limitations on manuscript length and extent of graphic presentations.

- TECHNICAL MEMORANDUM. Scientific and technical findings that are preliminary or of specialized interest, e.g., quick release reports, working papers, and bibliographies that contain minimal annotation. Does not contain extensive analysis.

- CONTRACTOR REPORT. Scientific and technical findings by NASA-sponsored contractors and grantees.
- CONFERENCE PUBLICATION. Collected papers from scientific and technical conferences, symposia, seminars, or other meetings sponsored or cosponsored by NASA.

- SPECIAL PUBLICATION. Scientific, technical, or historical information from NASA programs, projects, and missions, often concerned with subjects having substantial public interest.

- TECHNICAL TRANSLATION. Englishlanguage translations of foreign scientific and technical material pertinent to NASA's mission.

Specialized services that complement the STI Program Office's diverse offerings include creating custom thesauri, building customized databases, organizing and publishing research results ... even providing videos.

For more information about the NASA STI Program Office, see the following:

- Access the NASA STI Program Home Page at http://www.sti.nasa.gov

- E-mail your question via the Internet to help@sti.nasa.gov

- Fax your question to the NASA Access Help Desk at 301-621-0134

- Telephone the NASA Access Help Desk at 301-621-0390

- Write to:

NASA Access Help Desk

NASA Center for AeroSpace Information 7121 Standard Drive

Hanover, MD 21076 
NASA/TM-2005-213653

\section{Collection Efficiency and Ice Accretion Characteristics of Two Full Scale and One 1/4 Scale Business Jet Horizontal Tails}

Colin S. Bidwell

Glenn Research Center, Cleveland, Ohio

Michael Papadakis

Wichita State University, Wichita, Kansas

Prepared for the

SAE General Aviation Technology Conference and Exposition sponsored by the Society of Automotive Engineers

Wichita, Kansas, May 9-11, 2000

National Aeronautics and

Space Administration

Glenn Research Center 
Available from

NASA Center for Aerospace Information 7121 Standard Drive

Hanover, MD 21076
National Technical Information Service 5285 Port Royal Road Springfield, VA 22100

Available electronically at http://gltrs.grc.nasa.gov 


\title{
Collection Efficiency and Ice Accretion Characteristics of Two Full Scale and One 1/4 Scale Business Jet Horizontal Tails
}

\author{
Colin S. Bidwell \\ National Aeronautics and Space Administration \\ Glenn Research Center \\ Cleveland, Ohio 44135 \\ Michael Papadakis \\ Wichita State University \\ Wichita, Kansas 67260
}

\begin{abstract}
Collection efficiency and ice accretion calculations have been made for a series of business jet horizontal tail configurations using a three-dimensional panel code, an adaptive grid code, and the NASA Glenn LEWICE3D grid based ice accretion code. The horizontal tail models included two full scale wing tips and a 25\% scale model. Flow solutions for the horizontal tails were generated using the PMARC panel code. Grids used in the ice accretion calculations were generated using the adaptive grid code ICEGRID. The LEWICE3D grid based ice accretion program was used to calculate impingement efficiency and ice shapes. Ice shapes typifying rime and mixed icing conditions were generated for a 30 minute hold condition. All calculations were performed on an SGI Octane computer. The results have been compared to experimental flow and impingement data. In general, the calculated flow and collection efficiencies compared well with experiment, and the ice shapes appeared representative of the rime and mixed icing conditions for which they were calculated.
\end{abstract}

\section{NOMENCLATURE}

AAOA Aircraft-angle-of-attack, degrees

b Span of wing, $m$

HTC Convective heat transfer coefficient, $\mathrm{W} / \mathrm{m}^{2} / \mathrm{K}$

LWC Liquid Water Content, $\mathrm{g} / \mathrm{m}^{3}$

MVD Median Volume Diameter, $\mu \mathrm{m}$

$\mathrm{y} \quad$ Spanwise distance from root, $\mathrm{m}$

$\beta \quad$ Collection efficiency

\section{INTRODUCTION}

The last 20 years has brought great advances in the computer software and hardware industry, changes which have yielded a larger more sophisticated set of engineering design tools. Engineers now have quick, and accurate tools to handle just about any design task. Tasks that were once unmanageable or manageable only by Computational Fluid Dynamic (CFD) groups on expensive machines are now tractable by the ordinary design engineer. Calculations that once took 10 hours of computer time and 2 days of turnaround time on large supercomputers can now be made overnight on powerful, inexpensive personal computers. Design tasks that were once empirically based "arts” are now analytically based sciences. One such area that has benefitted greatly from these changes has been the design of aircraft ice protection systems.

The task of aircraft ice protection system design which was previously one of subjectivity, based heavily on correlation and extrapolation, and carried out by highly experienced individuals is now one of objectivity, 
based on sound models and carried out by entry level engineers. Historically systems have been designed using the methods of ADS-4 (ref. 1). This entailed interpolation or extrapolation from previously tested conditions and configurations. If a configuration or condition didn't exist in ADS-4 then various forms of extrapolation were used. As the aircraft industry progressed, newer designs were less and less similar to those in the ADS-4 database and the task of interpolation or extrapolation became more difficult and increased uncertainty. With the advent of the computer age numerical methods were made available, reducing the guess work. Many 2D and some 3D methods are now available to aid the user in designing an aircraft ice protection system (ref. 2-6). This paper outlines one such 3D method and presents validation for a series of business jet horizontal tails.

Flow, trajectory and ice accretion calculations were made and compared to experiment for the three horizontal tail configurations using the PMARC flow solver (ref. 7), the 3D adaptive grid code ICEGRID and the grid based NASA Glenn 3D ice accretion code LEWICE3D (ref. 6). The cases were chosen to illustrate the flexibility and to provide validation for the computer code.

Computational and experimental results are presented for flow, and collection efficiency for the three wing tips. All of the flow calculations were made using the PMARC flow solver. The aerodynamic and collection efficiency data were taken during a series of tests in the NASA Glenn Icing Research Tunnel (IRT) under a program funded by NASA and carried out by Wichita State University, Boeing Commercial Airplane Group, and NASA (ref. 8,9).

\section{EXPERIMENT}

\section{A. EXPERIMENTAL APPARATUS}

The aerodynamic and impingement efficiency tests were carried out in the NASA Glenn IRT. The test equipment included the IRT (fig. 1), the ESCORT data system, a special spray system for the impingement tests (fig. 2), a laser reflectometer for impingement efficiency data reduction (fig. 3), many blotter strips attached to the models (fig. 4), and the three tail models (fig. 5-7).

The IRT facility can provide a range of airspeeds, angles-of-attack, temperatures, liquid water contents (LWC), and drop sizes (ref. 10). The IRT has a $2.47 \mathrm{~m} \mathrm{x} 1.82 \mathrm{~m}$ test section with a maximum airspeed of $134 \mathrm{~m} /$ s (empty tunnel). Angle-of-attack is controlled by a movable turntable to which the models are mounted. A refrigeration system allows year-round testing at temperatures from $-29^{\circ} \mathrm{C}$ to $10^{\circ} \mathrm{C}$. The spray system located upstream of the test section can provide a cloud with a range of LWC of $0.25-3.0 \mathrm{gm} / \mathrm{m}^{3}$ and a median volumetric droplet diameter (MVD) size range of 12-40 $\mathrm{mm}$.

The Escort system was developed at Glenn to aid in storage, processing, and analysis of large amounts of data (e.g. temperature, pressure) produced in various experiments at Glenn Research Center. In this test Escort was used to store tunnel total temperature, total pressure, free stream airspeed, surface pressure, produce real time calculations and display pertinent parameters. The storage sequence for each data point was initiated by the researcher in the control room. A separate program was used to do a more complete post run analysis.

The spray requirements for the impingement tests precipitated the need for a different spray system (fig. 2) than was available in the IRT (ref. 8). The IRT spray system could not produce the short (2-9 seconds), stable sprays (i.e. constant LWC and drop size) required to prevent blotter strip saturation. There were also concerns that the dye would contaminate the IRT spray system. The new system consisted of 12 nozzles and a supply tank located at the IRT spray bar station (fig. 2). The system featured short supply lines which enabled short, stable sprays.

One unique feature of the current technique is the laser reflectometer used to determine the local collection efficiency (fig. 3). The device measures the local reflectance of the blotter strip and correlates this to the local collection efficiency (ref. 8). The device saved considerable time in the data reduction of the blotter strips. 
The first horizontal tail configuration presented is a swept, tapered NACA 64A008 wing tip (fig. 5). The model had a span of $121.92 \mathrm{~cm}$, a leading edge sweep angle of $29.1^{\circ}$, a root chord of $116.21 \mathrm{~cm}$, a taper ratio of 0.62 and a cylindrical tip. The model had two rows of 31 pressure taps at the $50 \%$ and $90 \%$ span stations.

The second horizontal tail configuration presented is a swept, tapered model with a modified NACA 64A008 wing section (fig. 6). The modified model had a slight droop at the leading edge to give it better aerodynamic performance characteristics. The model had a span of $144.78 \mathrm{~cm}$, a leading edge sweep angle of $29.1^{\circ}$, a root chord of $123.79 \mathrm{~cm}$, and a taper ratio of 0.58 .

The third horizontal tail configuration presented is a full tail configuration with a forebody (fig. 7). The horizontal tail was a $25 \%$ scale model of the second model presented above. The model was a swept, tapered model with a modified NACA 64A008 wing section. The model had a span of $65.51 \mathrm{~cm}$, a leading edge sweep angle of $29.1^{\circ}$, a root chord of $41.53 \mathrm{~cm}$, and a taper ratio of 0.43 . The model had three rows of 32 pressure taps at the 25\%, 50 and $85 \%$ span stations. During the IRT test only pressure data at the $25 \%$ span location was taken.

\section{B. EXPERIMENTAL TESTING}

Two types of testing were done in the IRT: aero-performance and impingement efficiency testing. The aero-performance testing involved taking surface pressure measurements. The impingement efficiency testing involved the use of a dye tracer technique to measure the location and amount of water impinging on the model.

Surface pressures were measured on the wing models using the ESCORT system. Pressure measurements were taken at an airspeed of $75 \mathrm{~m} / \mathrm{s}$, at angles-of-attack of $0^{\circ}$ and $6^{\circ}$ for the swept $64 \mathrm{~A} 008$ and for $1^{\circ}$ and $6^{\circ}$ for the $25 \%$ scale modified 64A008 wing model with the spray system off. These pressure measurements were used to generate coefficient of pressure distributions for the comparisons presented in this paper.

The experimental technique used in the current tests to determine the impingement characteristics of a body is one that was developed in the early 1950's with a few modifications (ref. 8). The technique involved spraying a dye-water solution of a known concentration onto a model covered with blotter strips. Figure 5 shows a typical blotter installation for the swept 64A008 wing. The result was that the local impingement efficiency on the blotter strips was related to the variation in color intensity. That is, the areas of higher impingement rate are darker and those with lower impingement rate are lighter.

Several steps were necessary to prepare the IRT for impingement testing. The specially designed spray system had to be installed and adjusted to produce a uniform cloud. The local LWC had to be measured at each blotter strip location (with the tunnel empty) for every spray and tunnel condition to account for any cloud non uniformity that existed after the final spray adjustment. After these adjustments and measurements were made the model was inserted and tested. Each test point was repeated four times to obtain a measure of the repeatability (ref. 8).

A typical test point involved several steps. The model was cleaned and blotter strips were attached at points of interest. Figures 4, 5 show typical blotter strip installations for the full scale modified NACA 64A008 and the swept NACA 64A008 wing models.The spray was then made, the blotter strips were removed, and labeled, and the model was cleaned and made ready for the next condition.

The tail models were tested for three drop sizes $(11 \mathrm{~mm}, 21 \mathrm{~mm}, 92 \mathrm{~mm})$, at two angles-of-attack $\left(0^{\circ}, 6^{\circ}\right.$ for the swept $64 \mathrm{~A} 008$ and $1^{\circ}, 6^{\circ}$ for the two modified swept 64A008 wings). The drop size tests were repeated three times for each condition to generate a statistical average. 


\section{ANALYTICAL METHOD}

The icing calculation required a three step process. All of the calculations were made on a single processor (R12000) of an SGI Octane computer. The ICEGRID code was used to generate the grid for the trajectory calculations. The PMARC code was used to generate the velocities on this grid and to generate the surface velocities needed in the LEWICE3D code. The LEWICE3D code then used the panel model the surface velocity information and the grid to make the ice accretion calculations.

\section{A. ICEGRID}

The ICEGRID was developed at Glenn Research Center by Bidwell and Coirier specifically for the task of optimizing trajectory calculations in the LEWICE3D code for the panel code interface. ICEGRID automatically produces grids which are optimal for trajectory calculations hence reducing the required effort to produce a "good" trajectory grid. The program also produces a minimum of grid points which reduces the panel code calculation times. The program requires the surface geometry and an input file describing the grid volume and refinement parameters. The code refines the grid near regions of interest which can include the geometry, parts of the geometry, and lines or points input by the user. The code is similar to an oct-tree method (ref. 11) in that it recursively divides the original grid volume until the refinement criteria for each cell has been met. The code will not refine cells internal to the geometry. ICEGRID is different from most oct-tree methods in that the grid volume is allowed to be multiply skewed, multiblock and different refinement functions can be used in any direction. This last feature is where the code really differs from the oct-tree methods in that it allows a given cell to be divided into 8, 4 or 2 cells depending on the refinement function instead of the oct-tree method which divides a cell into 8 cells if the refinement is required. This results in grids with much fewer cells for cases where gridding requirements are disparate in the different directions (e.g. swept wings which have a much smaller cell size requirement in the chordwise direction than in the spanwise direction).

The grids used in the icing calculations are shown in figures 5-7. The grids were all swept to align with the leading edge and were only generated for one side of the symmetry plane.

Cell size is critical in producing a good trajectory calculation. The panel and grid cell size must be similar and small enough to resolve the velocity gradients in the vicinity of the wing. The swept 64A008 grid model contained 216708 grid points. A minimum chordwise/surface normal grid spacing of $0.159 \mathrm{~cm}$ was used along with a minimum grid cell size of $5.08 \mathrm{~cm}$ in the span-wise direction. The maximum cell size for the grid was 40.64 $\mathrm{cm}$. The full scale modified 64A008 grid model contained 259066 grid points. A minimum chordwise/surface normal grid spacing of $0.159 \mathrm{~cm}$ was used along with a minimum grid cell size of $5.08 \mathrm{~cm}$ in the span-wise direction. The maximum cell size for the grid was $40.64 \mathrm{~cm}$. The $25 \%$ scale modified 64A008 panel model contained 224582 grid points. A minimum chordwise/surface normal grid spacing of $0.04 \mathrm{~cm}$ was used along with a minimum grid cell size of $1.27 \mathrm{~cm}$ in the span-wise direction. The maximum cell size for the grid was $10.16 \mathrm{~cm}$. The grid plane at $y=0$ shows the major features of the grid. It took approximately 1 hour of CPU time to generate each of the grids.

\section{B. PMARC}

PMARC is a first order 3D potential flow panel code (ref. 7). Geometries are represented as quadrilaterals which have constant doublet and source distribution. The formulation used in PMARC results in a solution that is second order accurate allowing for accurate flow solutions with fewer panels and less CPU time than other first order methods. The disadvantage of this method is that because a numerical differentiation is used to generate the velocity distribution careful panelling is required to prevent numerical errors. The code can generate solutions for internal and external compressible flows and can handle very large problems ( 10,000 panels).

For the current study, PMARC was executed using a steady, isolated flow with a y $=0$ plane of symmetry (fig. 5-7). The swept 64A008 panel model contained 2303 panels, the full scale modified 64A008 panel model 
contained 2162 panels and the 25\% scale modified 64A008 panel model contained 2162 panels. Flow solutions were calculated for two angles-of-attack $\left(0^{\circ}, 6.25^{\circ}\right.$ for the $64 \mathrm{~A} 008$ model and $1^{\circ}, 6^{\circ}$ for the full scale modified 64A008 and $2^{\circ}, 7^{\circ}$ for the $25 \%$ scale modified 64A008 model. In cases where surface pressure information was available (i.e. the swept 64A008 model and the 25\% scale modified 64A008 model) an attempt to match the analytical and experimental pressure distributions was made by varying the analytical angle-of-attack. In these cases, the analytical and experimental angles-of-attack are different. Matching the pressure distributions insured that the experimental and analytical flow models were at the same effective angle-of-attack which is key in the consistency of the collection efficiency comparisons (ref. 9) The flows solutions and velocity calculations took approximately 150 minutes for each of the cases.

\section{LEWICE3D}

The LEWICE3D grid based code incorporates trajectory, heat transfer and ice shape calculation into a single computer program. The code can handle generic multiblock structured grid based flow solutions, unstructured grid based flow solutions, simple cartesian grids with surface patches, and adaptive grids with surface patches. The latter two methods allow the use of generic panel code input which is a computationally efficient method for generating ice shapes. The code can handle overlapping and internal grids and can handle multiple planes of symmetry. Calculations of arbitrary streamlines and trajectories are possible. The code has the capability to calculate tangent trajectories and impingement efficiencies for single droplets or droplet distributions. Ice accretions can be calculated at arbitrary regions of interest in either a surface normal or tangent trajectory direction. The LEWICE3D code has been used in previous calculations for isolated wings, inlets, ducts, and full aircraft configurations (ref. 12-18).

The methodology used in the LEWICE3D (ref. 6) analysis can be broken into six basic steps for each section of interest at each time step. In the first step, the flow field is generated by the user. Secondly, surface streamlines are calculated. The surface streamline analysis uses a variable step size fourth-order Runge-Kutta integration scheme developed by Bidwell (ref. 6). Thirdly, tangent trajectories are calculated at the region of interest. An array of particles is released between the tangent trajectories in the fourth step. These impacting particles are used to calculate collection efficiency as a function of surface position. The trajectory analysis is basically that of Hillyer Norment (ref. 19) with modifications by Bidwell (ref. 6). At the heart of the trajectory analysis is the variable step predictor-corrector integration scheme by Krogh (ref. 20). The fifth step involves interpolating or extrapolating the collection efficiencies onto the streamlines. In the sixth step the ice accretion for the streamline is calculated. The ice accretion model is basically that of the LEWICE2D code applied along surface streamlines (ref. 3).

LEWICE3D calculation times varied for the different cases depending upon the drop size and the number of trajectories. The LEWICE3D calculation times are heavily dependent upon grid size and structure because the largest portion of the LEWICE3D calculation time (greater than 99\%) is spent calculating velocities at specified points, which involves searching through the grid tree structure for the cell in which the point is located. The trajectory integration time for the cases varied from 0.02-0.05 seconds. Approximately 100 trajectories were required for each drop size at each section-of-interest for the ice accretion calculations. This resulted in calculation times of approximately 250-500 seconds for each of the tail cases (2 sections-of-interest, 27 bin distribution).

\section{ANALYSIS}

Surface velocity, heat transfer, collection efficiency, and ice shapes results are presented for the horizontal tails. Ice shape calculations were made for two icing conditions simulating a rime and a mixed condition. Comparisons to experimental collection efficiency are made for all of the cases and to experimental coefficient of pressure where available. Discussions of the icing conditions chosen, the LEWICE3D program parameters used, and of the individual analysis are given below. 
Two icing conditions were calculated for each of the tails at each angle-of-attack. The icing conditions were chosen to loosely match a rime and a mixed hold condition. A 27 bin distribution with a Median Volume Diameter (MVD) drop size of $21 \mathrm{~mm}$ was used for both of the icing conditions. For the rime condition, an icing time of 30 minutes, an LWC of $0.2 \mathrm{~g} / \mathrm{m}^{3}$ and a temperature of $243.1 \mathrm{~K}$ were used in the calculations. For the mixed condition an icing time of 30 minutes, an LWC of $0.695 \mathrm{~g} / \mathrm{m}^{3}$ and a temperature of $263.7 \mathrm{~K}$ were used in the calculations.

The grid based LEWICE3D computer program parameters were chosen from experience, correlations and a desire to limit the computational resources required. A 27 bin experimentally measured droplet distribution (ref. 9) was used for the calculations. The icing calculations were made using a single ice accretion time step. A LEWICE roughness parameter (ref. 3) of $0.5 \mathrm{~mm}$ was used for all of the cases.

Figures 8-12 show typical repeatability for the gathered collection efficiency data. Because of the statistical nature of the data several repeats were taken to generate a useful average for the collection efficiency distributions. Figures 8,9 are representative of a typical set of data. The multiple repeats in these figures were within $\pm 5.2 \%$ and $\pm 5.5 \%$ respectively. Figure 10,11 represent the best and the worst data in terms of repeatability for the data presented in the report with repeatability of $\pm 2.2 \%$ and $\pm 9.3 \%$ respectively. Values of repeatability of $\pm 10 \%$ are considered good by the researchers considering the test technique and environment.

The results for the horizontal tails are shown in figures 12-66.The ice shape and parameter plots were made along cuts parallel to the flow direction.

The airfoil sections at which the icing calculations were made are shown in figure 12. The sectional cuts were relatively close together hence the sections are of similar size as were resultant ice shapes.

The experimental and theoretical coefficient of pressure distributions are shown in figures 13,14 for the swept 64A008 wing. Due to flow angularity, model alignment, and wall effects the measured angle-of-attack and the effective aerodynamic angle-of-attack can be different. For this reason the analytical flow angle was adjusted to produce the closest agreement between the experimental and analytical pressure distributions. These adjusted angles-of-attack were then used in all of the analysis. The best agreement for the experimental angle-of-attack of $0^{\circ}$ was an analytical angle-of-attack of $0^{\circ}$. The best agreement for the experimental angle-of-attack of $6^{\circ}$ was an analytical angle-of-attack of $6.25^{\circ}$. In general, the agreement between the experimental and theoretical coefficient of pressures for both angles-of-attack was good. From the figures very little spanwise difference in the pressure distribution can be seen.

The collection efficiency comparisons between experiment and LEWICE3D are shown in figures 15-20 for the swept NACA 64A008 tail. The analysis and experiment showed little difference between the two sectional cuts. For this reason only the collection efficiency for the outboard station were presented. The figures show an increase in the size of impingement region and maximum collection efficiency with increased drop size. From the figures it can also be seen that as the angle-of-attack increases the extent of impingement increases. The agreement between experiment and theory is good for all but the largest drop size (i.e. MVD, 92mm). This disagreement has been attributed to droplet splashing or bouncing which has not been accounted for in the analysis. Studies are currently being planned to develop correlations to account for this effect in the trajectory analysis.

The ice shape analysis for the NACA swept 64A008 wing is summarized in figures 21-30. The figures depict a rime and a glaze ice hold condition for two angles-of-attack.

The coefficient of pressure and heat transfer coefficient distributions for the $0^{\circ}$ and $6^{\circ}$ angle-of-attack cases are shown in figures 21,22 and figures 26, 27 respectively. The heat transfer coefficient in the integral boundary layer calculation is based predominantly on surface velocities of which the coefficient of pressure is a 
measure. Hence the heat transfer coefficient is heavily dependent upon the coefficient of pressure distribution. The coefficient of pressure distribution for the $0^{\circ}$ angle-of-attack case is symmetrical and jumps rapidly at the leading edge and thereafter is benign (due to the sharp leading edge and the symmetric nature of the NACA 64A008 wing section). This results in a symmetric heat transfer coefficient distribution with relatively large peaks near the leading edge. These two symmetrical peaks occur at the transition point from laminar to turbulent flow. Turbulent flow generates much higher heat transfer than laminar flow hence there is a jump in the heat transfer at the transition point. The coefficient of pressure distribution for the $6^{\circ}$ angle-of-attack case (fig. 27) has an asymmetrical distribution with a large pressure peak on the upper surface and a smaller one on the lower surface. This is reflected in the heat transfer distribution which is asymmetric and which has a much higher peak value on the upper surface than on the lower surface. For both angles-of-attack very little spanwise difference in both pressure coefficient distribution and heat transfer coefficient distribution is evident.

The collection efficiency curves for the two angles-of-attack are shown in figures 23 and 28. The effect of increased angle-of-attack is to increase the extent of impingement and the to move the impingement region more towards the underside of the wing.

The glaze ice shapes for the two angles-of-attack are shown in figures 24 and 29. The glaze shapes are heavily dependent on the heat transfer coefficient distribution. This is because for these cases (i.e. glaze), there is more water than can be frozen and the largest factor controlling the amount of water to be frozen is the amount of local heat transfer and hence the local heat transfer distribution. For this reason ice thickness distribution and hence the ice shape under glaze conditions will be derived predominantly from the heat transfer coefficient distribution. The horns will form where there is a maximum in freeze out which occurs at the position of maximum heat transfer which is at the transition point.

The rime ice shapes for the two angles-of-attack are depicted in figures 25 and 30. For the rime cases there is less water than can be frozen hence the water freezes on impact and there is no runback. For the rime cases, the driving factor behind the ice thickness and the ice shape is the amount of incoming water or collection efficiency. The ice thickness distribution and the resulting ice shape are derived predominantly from the collection efficiency distribution. From the figures we see that the ice shapes are conformal with the peak ice thickness occurring at the location of maximum collection efficiency. The effect of increasing the angle-of-attack is to shift the ice shape more towards the bottom of the wing.

Airfoil sections for the full scale modified NACA 64A008 are shown in figure 31. Because these sections were of similar size the parameter plots and ice shapes presented below were almost identical. The IRT model did not have any pressure instrumentation hence no experimental values for coefficient of pressure were presented for this wing.

Figures 32-37 show the collection efficiency comparisons between LEWICE3D and experiment. The comparisons are good except for the $92 \mathrm{~mm}$ for which the code overpredicts the amount of water collected almost everywhere. These differences, as explained above, have been attributed to splashing and bouncing of some of the incoming water in the experiment which resulted in a loss of water at the surface. The trends for collection efficiency are similar to those of the swept NACA-64A008 wing above. The extent of impingement and the maximum collection efficiency increased with increasing drop size. The effect of increasing angle-of-attack was to increase the extent of impingement and move the region of impingement more towards the underside of the wing.

The results for the icing analysis for the wing are shown in figures 38-47. Of interest is the similarity in the parameter plots and ice shapes between the swept 64A008 wing and the full scale modified 64A008 wing. This is because of the similarity of the two models in section, size and sweep angle.

The coefficient of pressure distribution and the heat transfer coefficient distributions for both angles-of- 
attack are shown in figures 38,39 and figures 43,44 respectively. Because no surface pressure data was gathered for the modified swept 64A008 wing the analytical angle-of-attack used was the same as the geometric angle-ofattack measured in the IRT (i.e. $0^{\circ}$ and $6^{\circ}$ ). The results for pressure distribution and heat transfer coefficient distribution for this wing were similar to the swept 64A008 wing above, again because of the similarity in the wings. The maximum heat transfer coefficients for the two angles-of-attack for the modified 64A008 wing were slightly smaller than those of the 64A008 wing above because of the slightly larger leading edge radius of the modified wing (i.e. larger wing chord).

Collection efficiency results and ice shapes for both icing conditions and angles-of-attack are shown in figures 40-42 and figures 45-47 respectively. As for the swept 64A008 wing the glaze ice shapes follow trends set by the heat transfer and the rime shapes follow trends set by the collection efficiency distributions. That is, for the glaze shape the minimum ice thickness and heat transfer coefficient occur at the stagnation point and the maximum ice thickness (horns) occur at the points of maximum heat transfer coefficient (i.e. transition point). For the rime ice shapes the maximum collection efficiency and ice thickness occur at the stagnation point and the ice thickness distribution has the same shape as the collection efficiency distribution.

The wing sections for the $25 \%$ scale tail for which the icing analysis were done are shown in figure 48 . The wing sections are of the same type as those of the modified 64A008 above. The model was a $25 \%$ scale version of the modified 64A008 wing hence the sections were much smaller and were on the order of one third the size of the sections for the model above.

Comparisons of the experimental and analytical coefficient of pressure distributions for the $25 \%$ tail are shown in figures 49,50. Analytical angles-of-attack of $2^{\circ}$ and $7^{\circ}$ resulted in generating good agreement to the experimental coefficient of pressure distributions for $1^{\circ}$ and $6^{\circ}$ respectively.

Collection efficiency comparisons for the 25\% scale wing are shown in figures 51-55. As for the previous models the maximum collection efficiency and extent of impingement increased with increasing drop size and the impingement region increased and moved more towards the underside of the wing with increased angle-ofattack. The differences between LEWICE3D and experiment were small except for the $92 \mathrm{~mm}$ cases which were due to droplet splashing and bouncing. The results for the two spanwise stations were almost identical for each of the cases due to the similarity in size. The maximum collection efficiencies for the $25 \%$ scale model are significantly higher than the two previous models because of relatively smaller chord of the $25 \%$ wing.

The analytical coefficient of pressure and heat transfer coefficient distributions for the 25\% wing tip for the angles-of-attack of $2^{\circ}$ and $7^{\circ}$ are shown in figures 57,58 and figures 62,63 respectively. The distributions exhibit the same trends as noted for the two models above. The peak heat transfer coefficients are higher for the $25 \%$ scale model for both angles-of-attack because of the smaller chord and hence small leading edge radius.

The collection efficiency and ice shape results for both angles-of-attack are shown if figures 59-61 and figures 64-66. As with the other two wings the glaze ice and rime ice shapes follow trends set by the heat transfer coefficient and collection efficiency distribution respectively.

The ice shapes for the $25 \%$ scale model are disproportionately larger than for the larger models because the smaller model exhibited a larger stagnation heat transfer coefficient, a larger peak heat transfer coefficient and a larger maximum collection efficiency than the larger models. These effects can be seen if one looks at the ice thickness at the stagnation point. For both the rime and the glaze conditions at a given angle-of-attack the maximum ice thickness is slightly larger for the smaller model than for either of the larger models. The larger models only exhibited larger ice shapes in terms of volume because the extent of impingement and total water collected was higher than for the smaller model. 


\section{CONCLUSIONS}

The grid based LEWICE3D-PMARC-ICEGRID combination proved to be an inexpensive, flexible, accurate ice protection system design tool. The flow and ice accretion calculations were done quickly, cheaply and accurately for a range of 3D conditions.

The ICEGRID, PMARC, grid based LEWICE3D, combination was, in general, inexpensive to operate. The grid calculation took approximately 1 hour and the PMARC flow calculations took on the average of 2.5 hours for each of the flow configurations on the SGI Octane computer. The single time step ice accretion calculations required about 0.1 hours per ice shape using a 27 bin distribution.

In general, the calculations for coefficient of pressure agreed well with experiment. The pressure data allowed the user to more precisely set the angle-of-attack for the collection efficiency calculations.

The collection efficiency results from the experiment and analysis compared well except the $92 \mathrm{~mm}$ cases. For these cases the collection efficiency was significantly overpredicted. These differences were attributed to droplet splashing and bouncing, phenomena which have not been included in the trajectory analysis, and which plans are currently under way to study. The maximum collection efficiency and extent of impingement increased with increasing drop size and the extent of impingement increased and moved more towards the underside of the wing for increasing angle-of-attack. The effect of reducing the leading edge radius was to increase the maximum collection efficiency.

Although no data existed for heat transfer the results were reasonable and intuitive. The heat transfer coefficient distributions were indicative of the pressure distributions from which they were derived. The maximum heat transfer coefficient increased with increasing angle-of-attack and with decreased leading edge radius.

The ice shape predictions appeared acceptable and representative of the conditions from which they were derived. The rime and mixed shapes followed trends set by the collection efficiency and heat transfer coefficient, respectively. The ice shapes were disproportionately larger with decreasing chord because of the increases in maximum collection efficiency, and maximum heat transfer coefficient. 


\section{REFERENCES}

1. Bowden, D., Gensemer, A., Skeen, C., “Engineering Summary of Airframe Icing Technical Data,” FAA ADS-4, Dec. 1963.

2. Lozowski, E., Oleskiw, M., "Computer Modeling of Time-Dependent Rime Icing in the Atmosphere," CRREL 83-2, Jan. 1983.

3. Ruff, G.A., Berkowitz, B.M., "Users manual for the NASA Lewis Ice Accretion Prediction code (LEWICE),” NASA CR 185129, May 1990.

4. Cebeci, T., Chen, H., Alemdaroglu, N., "Fortified LEWICE with Viscous Effects.” AIAA Paper 90-0754, Jan. 1990.

5. Cansdale, J., Gent, R., "Ice Accretion on Aerofoils in Two-Dimensional Compressible Flow - A Theoretical Model,” RAE TR 82128, Jan. 1983.

6. Bidwell, C., Potapczuk, M., "Users Manual for the NASA Lewis Three-Dimensional Ice Accretion Code (LEWICE3D),” NASA TM 105974, Dec. 1993.

7. Ashby, D., Dudley, M., Iguchi, S., "Development and Validation of an Advanced Low-Order Panel Method,” NASA TM-101024, Oct. 1988.

8. Papadakis, M., Elangonan, G., Fruend, G., Breer, M., Whitmer, L., “An Experimental Method for Measuring Water Droplet Impingement Efficiency on Two-and Three-Dimensional Bodies,” NASA CR 4257, DOT/ FAA/CT-87/22, Nov. 1989.

9. Papadakis, M., Hung, E., Bidwell, C., Breer, M., "Experimental Investigation of Water Impingement on Single and Multi-Element Airfoils,” AIAA-2000-0100, Jan. 2000.

10. Soedher, R., Andracchio, C., “NASA Lewis Icing Research Center Tunnel User Manual,” NASA TM 82790, Jan. 1990.

11. Johnson, F., Samant, S., Bieterman, M., Melvin, R., Young, D., Bussoletti, J., and Hilmes, C., “TranAir: A Full-Potential, Solution-Adaptive, Rectangular Grid Code for Prediciting Subsonic, Transonic, and Supersonic Flows About Arbitrary Configurations,” NASA CR 4348, Dec. 1992.

12. Potapczuk, M., Bidwell, C., “Swept Wing Ice Accretion Modeling,” NASA TM 103114, Jan. 1990.

13. Potapczuk, M. and Bidwell, C., "Numerical Simulation of Ice Growth on a MS-317 Swept Wing Geometry,” NASA TM 103705, Jan. 1991.

14. Reehorst, A., "Prediction of Ice Accretion on a Swept NACA 0012 Airfoil and Comparisons to Flight Test Results,” NASA TM 105368, Jan. 1992.

15. Mohler, S., Bidwell, C., "Comparison of Two-Dimensional and Three-Dimensional Droplet Trajectory Calculations in the Vicinity of Finite Wings,” NASA TM 105617, Jan. 1992.

16. Bidwell, C., Mohler, S., "Collection Efficiency and Ice Accretion Calculations for a Sphere, a Swept MS(1)317 Wing, a Swept NACA-0012 Wing Tip, an Axisymmetric Inlet, and a Boeing 737-300 Inlet,” NASA TM 106831, Jan. 1995. 
17. Bidwell, C., Pinella, D., Garrison, P., "Ice Accretion Calculations for a Commercial Transport Using the LEWICE3D, ICEGRID3D, and CMARC Programs,” NASA/TM 1999-208895, Jan. 1999.

18. Al-Khalil, K., Hitzigrath, R., Phillippi, O., Bidwell, C., "Icing Analysis and Test of a Business Jet Engine Inlet Duct,” AIAA-2000-1040, Jan. 2000.

19. Norment, H., "Calculation of Water Drop Trajectories To and About Three-Dimensional Lifting and Nonlifting Bodies In Potential Airflow,” NASA CR 3935, Oct. 1985.

20. Krogh, F. "“Variable Order Integrators for Numerical Solutions of Ordinary Differential Equations,” Jet Propulsion Lab Technology Utilization Document No. CP-32308, Nov. 1970 


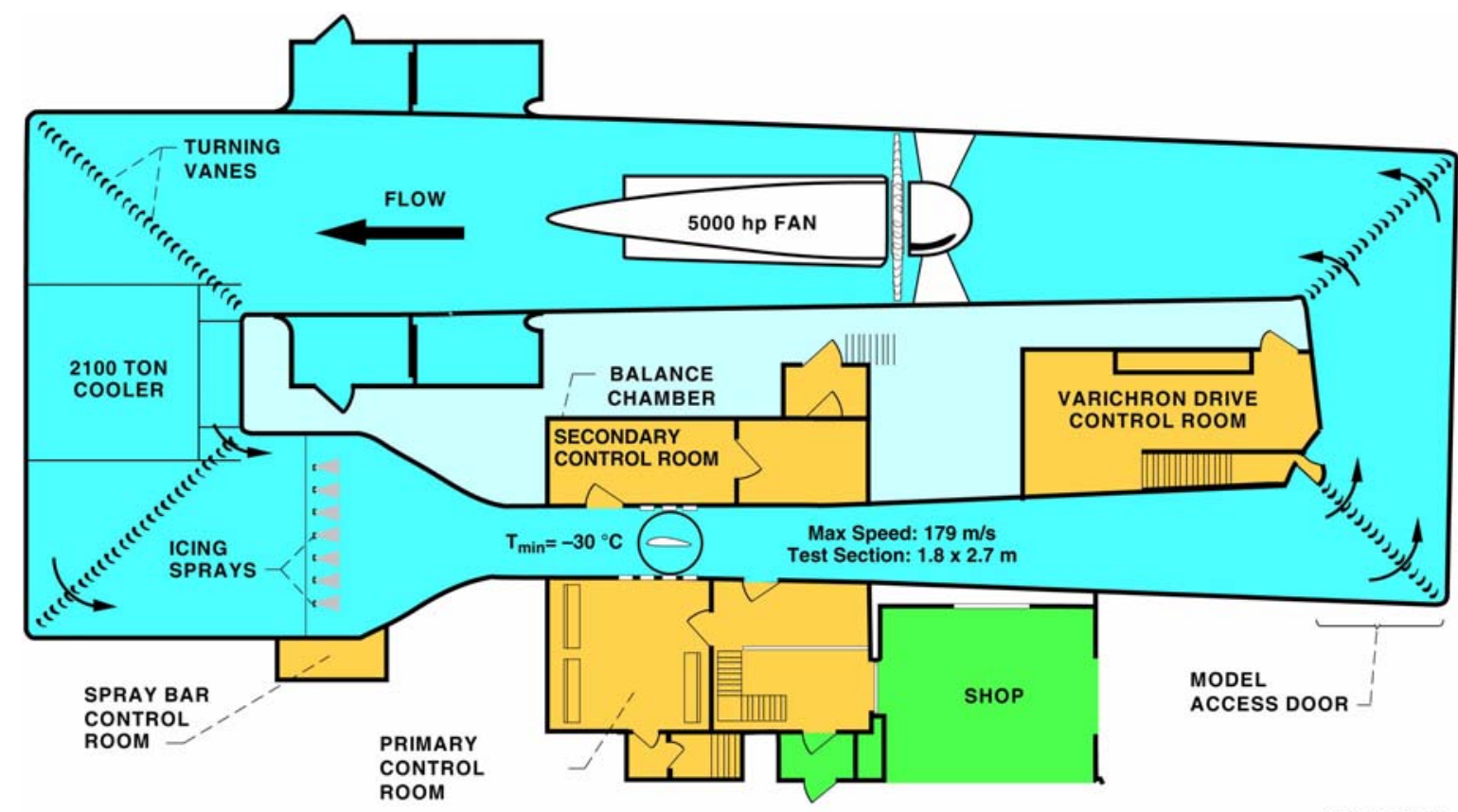

CD-95-70802

Figure 1: NASA Lewis Icing Research Tunnel. Plan view.

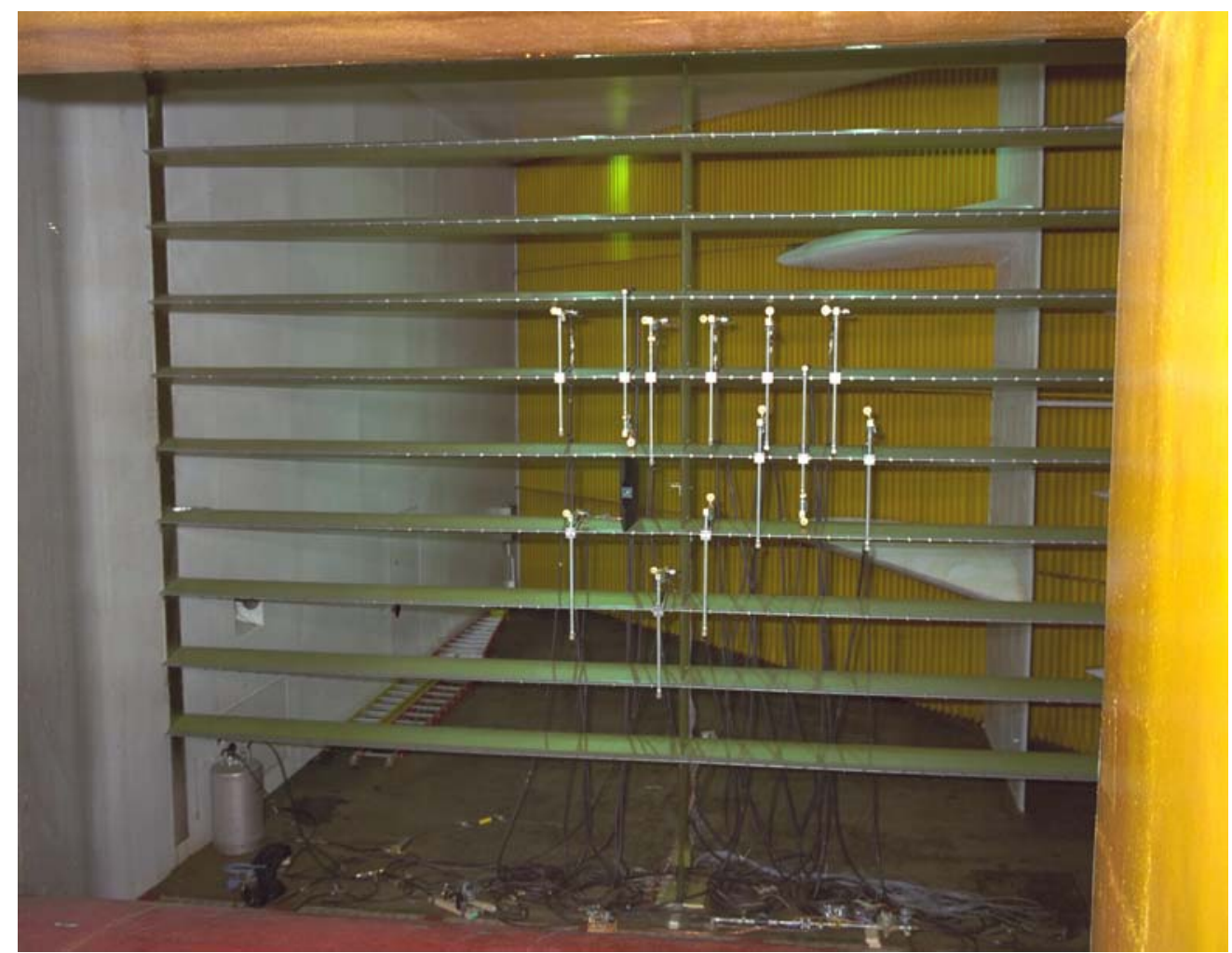

Figure 2: Installation of spray system used for Icing Research Tunnel impingement tests. 


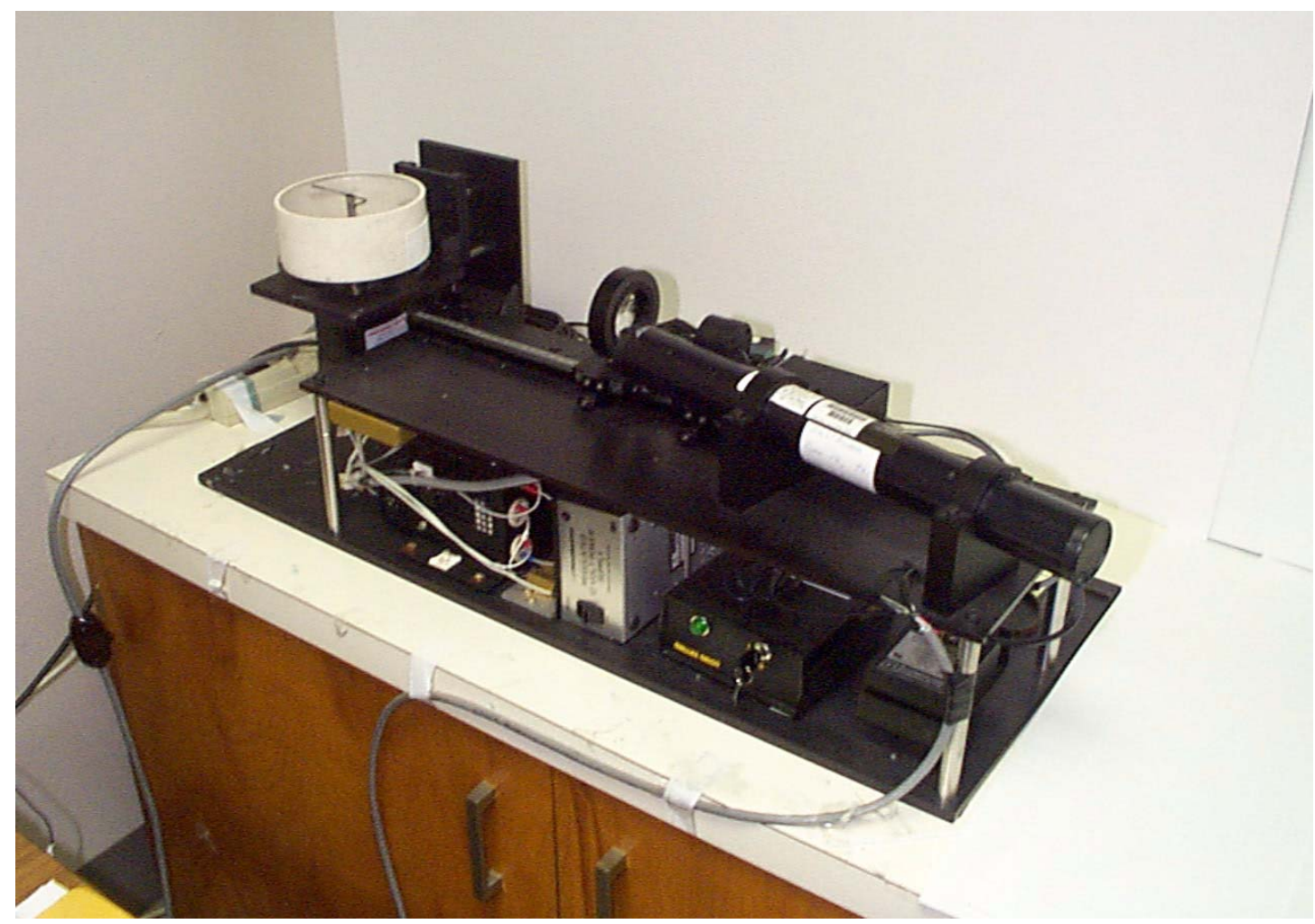

Figure 3: Automated reflectometer used to reduce impingement data.

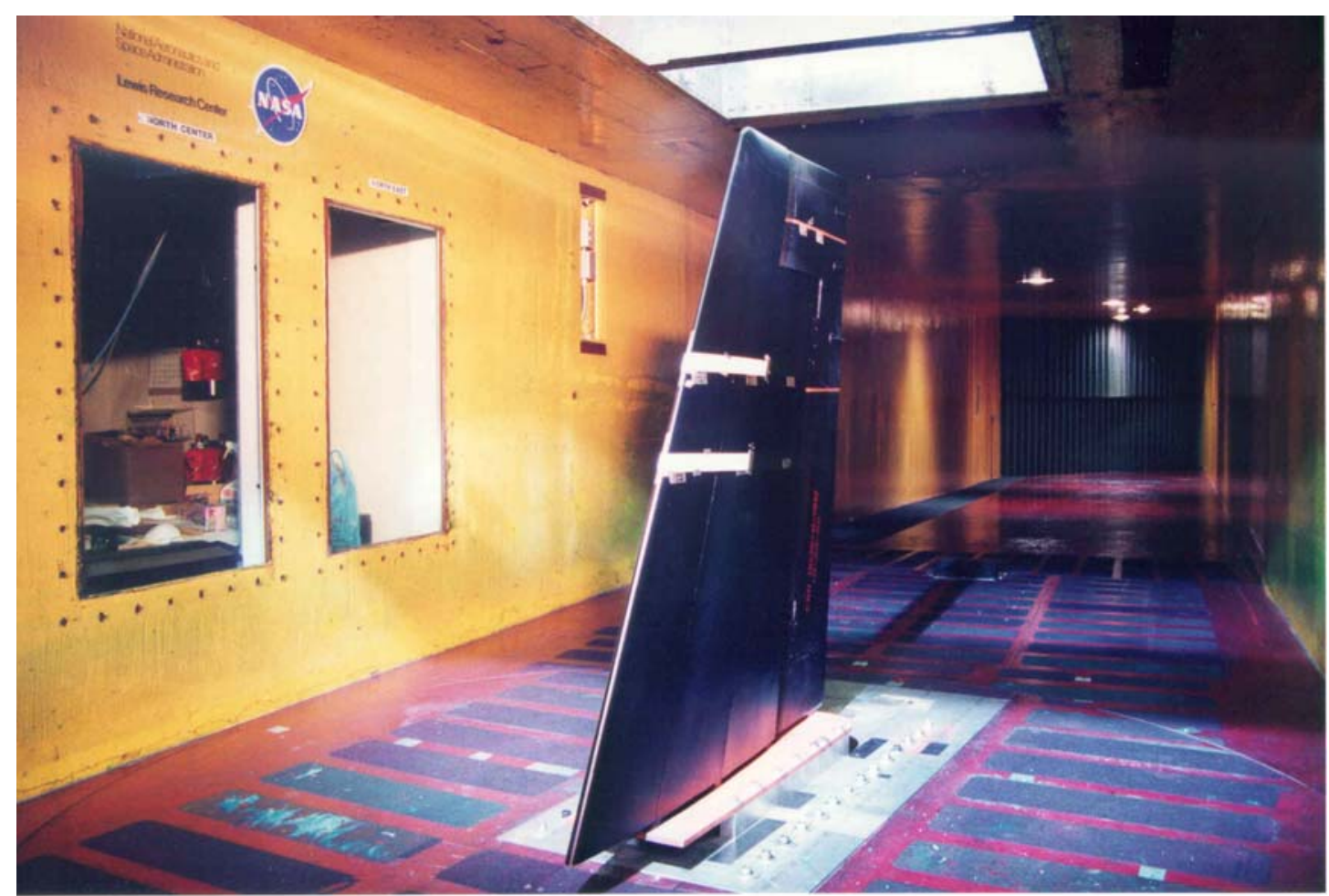

Figure 4: Illustration of wing blotter strip installation. 


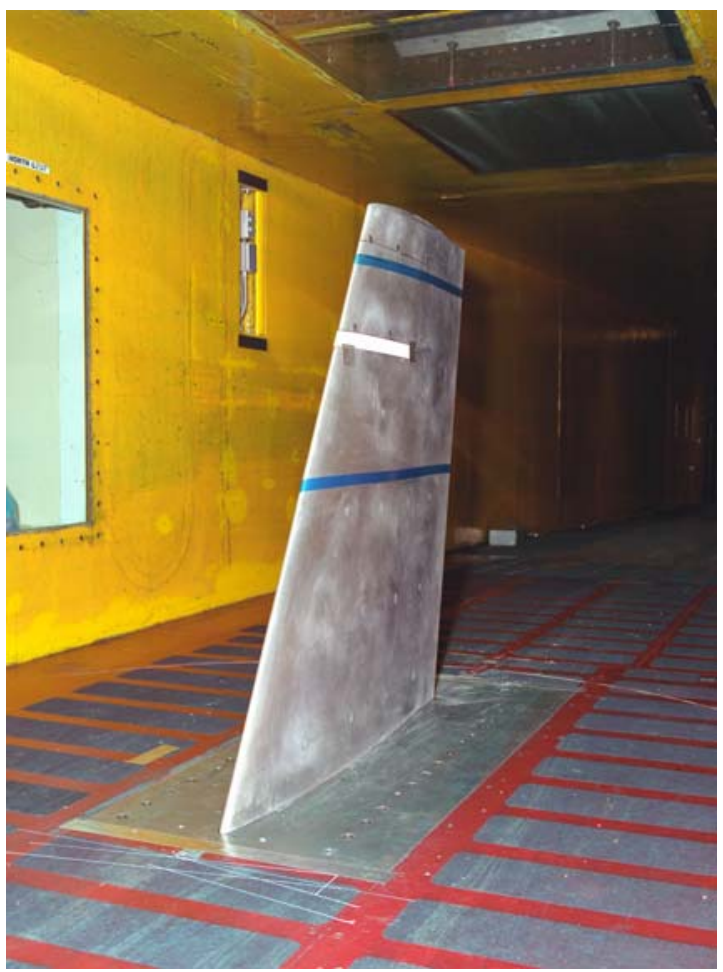

(a) Installation in IRT.

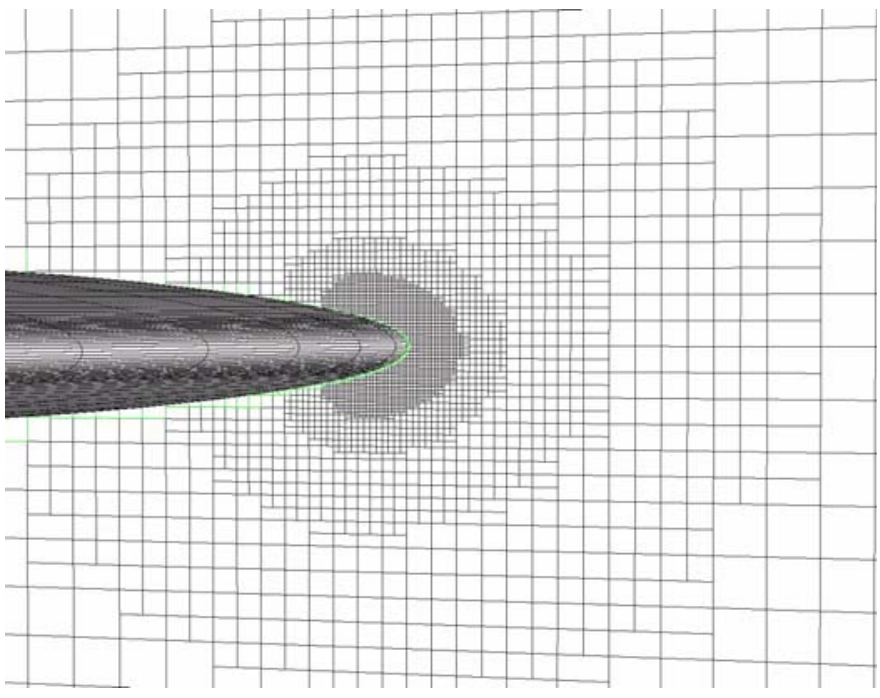

(c) Grid at $Y=0$ plane.

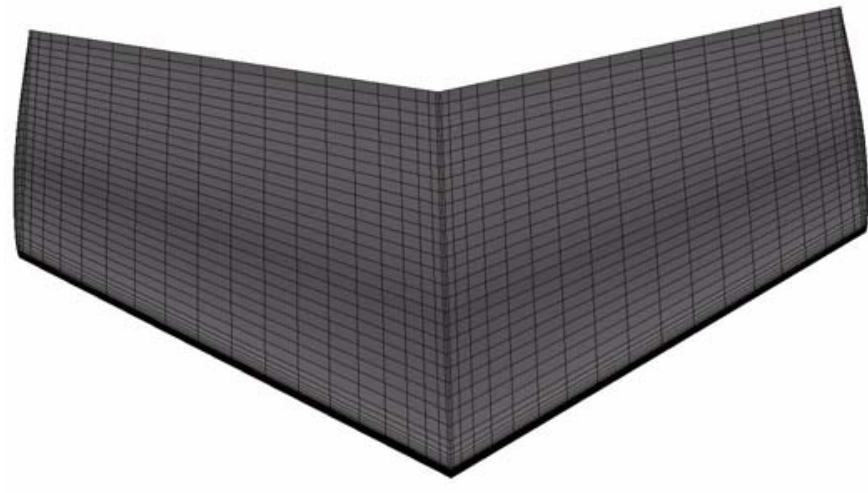

(b) PMARC panel model.

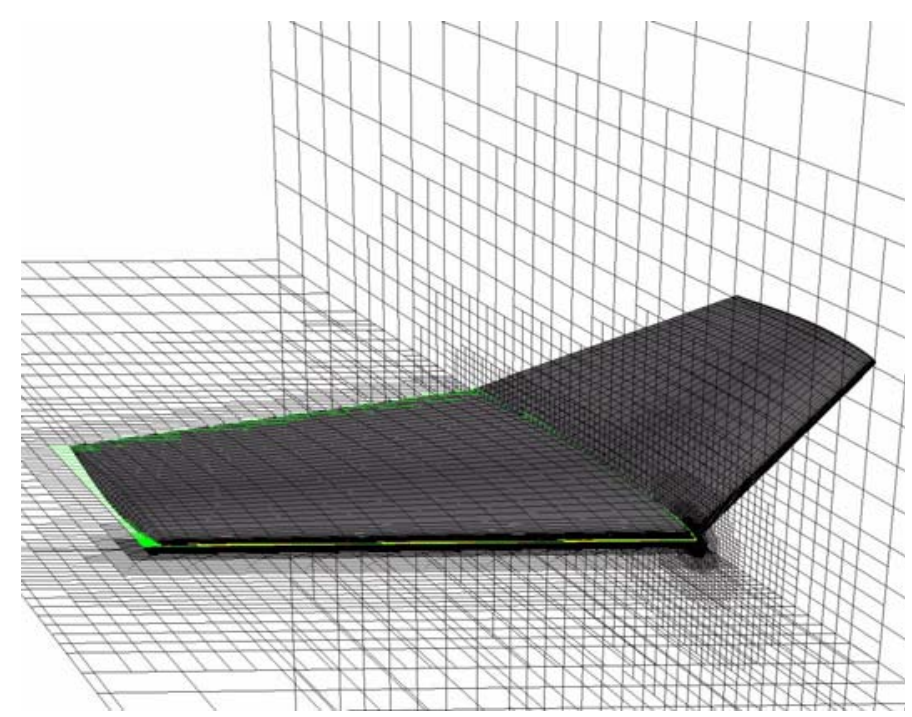

(d) PMARC panel model and grid.

Figure 5: Swept NACA 64A008 wind tunnel model and anayltical flow model. 


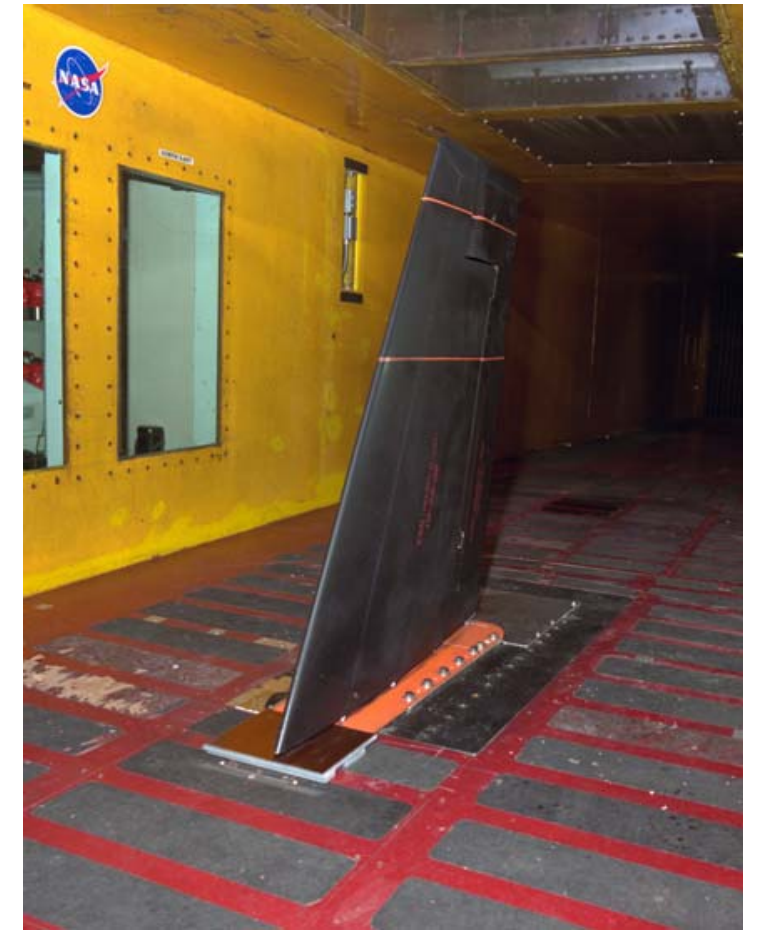

(a) Installation in IRT.

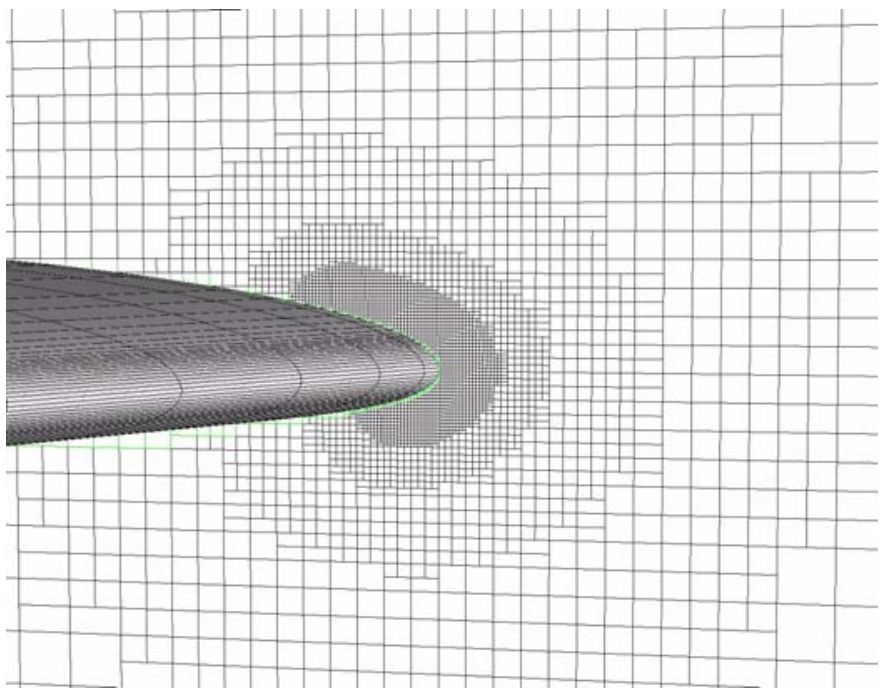

(c) Grid at $Y=0$ plane.

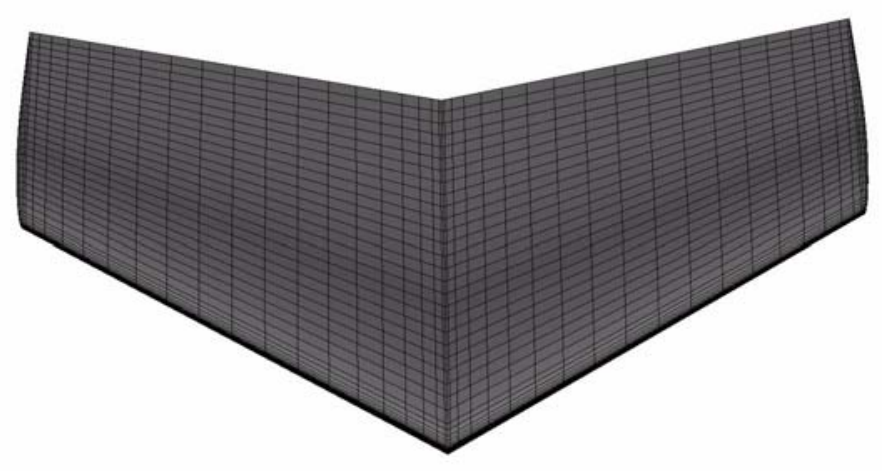

(b) PMARC panel model.

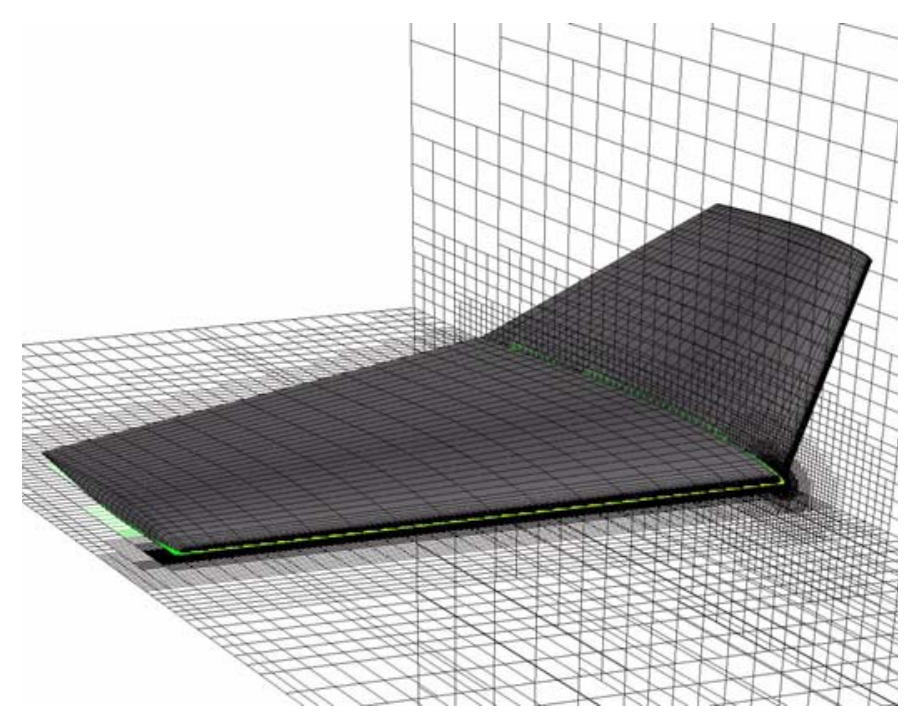

(d) PMARC panel model and grid.

Figure 6: Wind tunnel and anayltical flow model for full scale horizontal taill. 

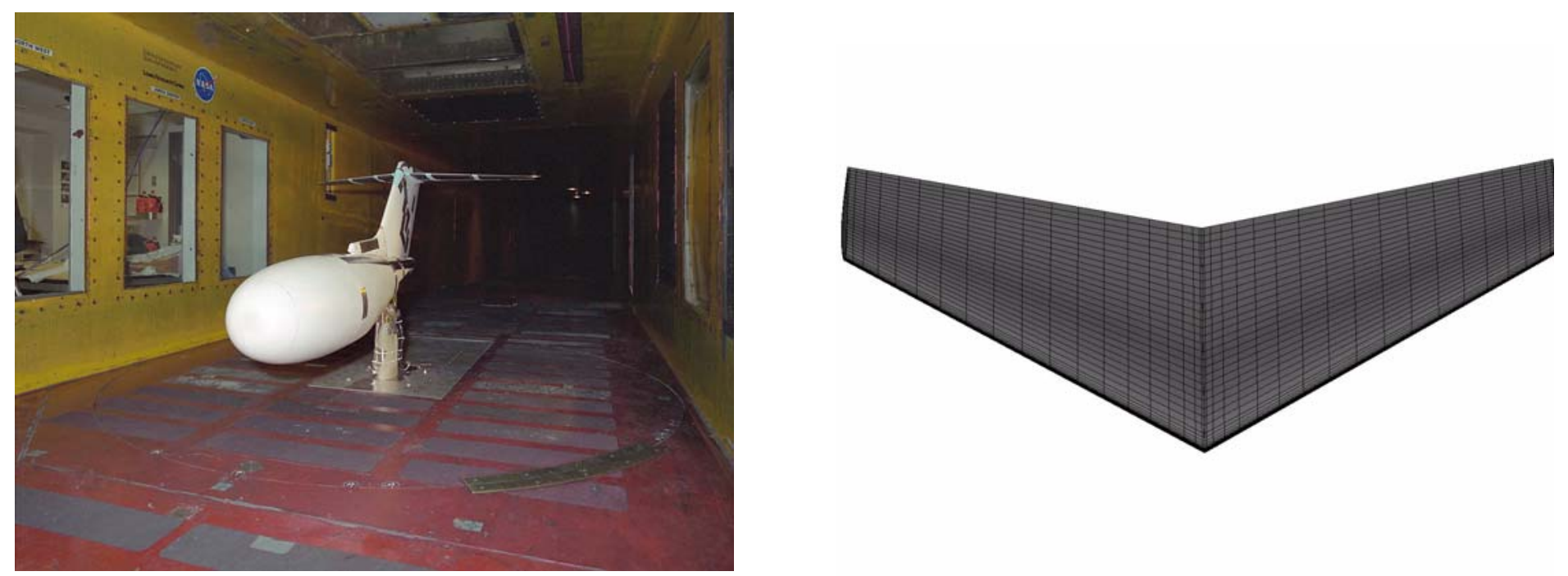

(a) Installation in IRT.

(b) PMARC panel model.

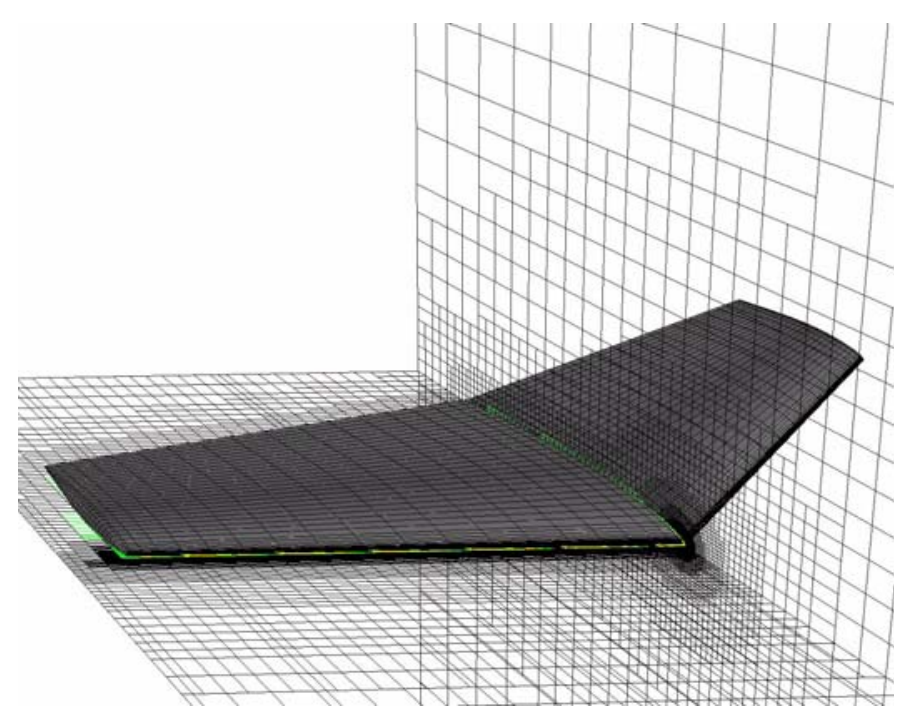

(c) Grid at $Y=0$ plane.

(d) PMARC panel model and grid.

Figure 7: Wind tunnel and anayltical flow model for $25 \%$ scale horizontal tail. 


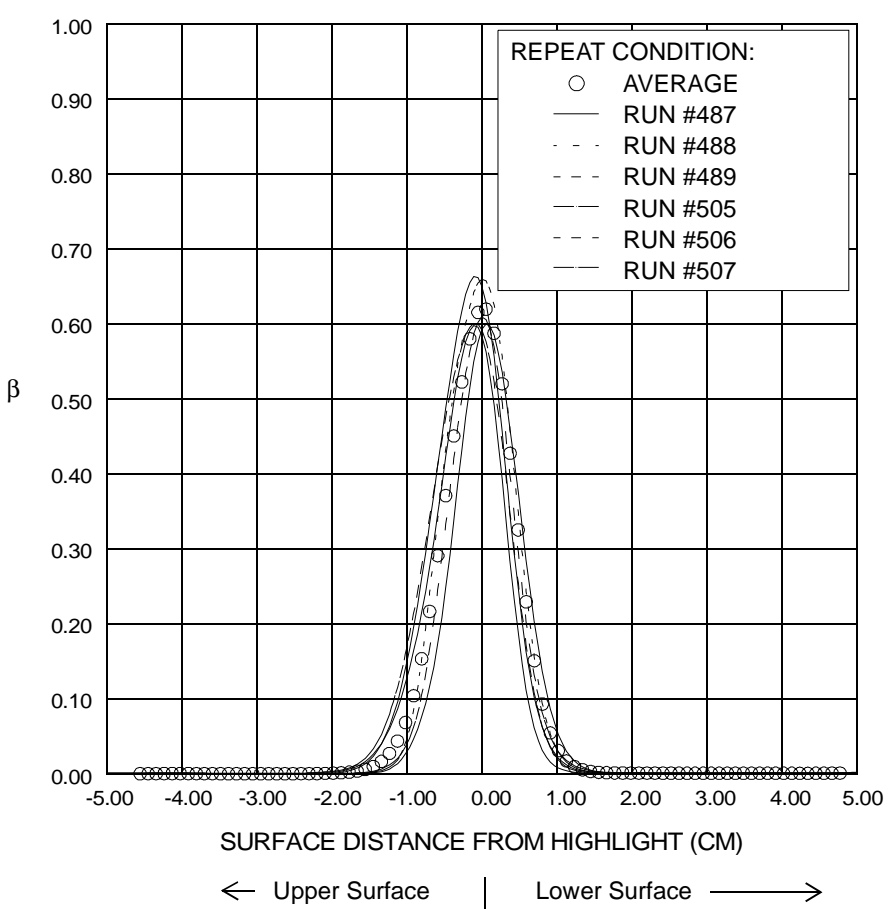

Figure 8: Experimental Collection Efficiency for the 25\% scale wing tip for angle-of-attack, $1^{\circ}$; airspeed, 75 $\mathrm{m} / \mathrm{s}$; static temperature, $7^{\circ} \mathrm{C}$; static pressure, $95840 \mathrm{~Pa}, \mathrm{MVD}, 11 \mu \mathrm{m}$.

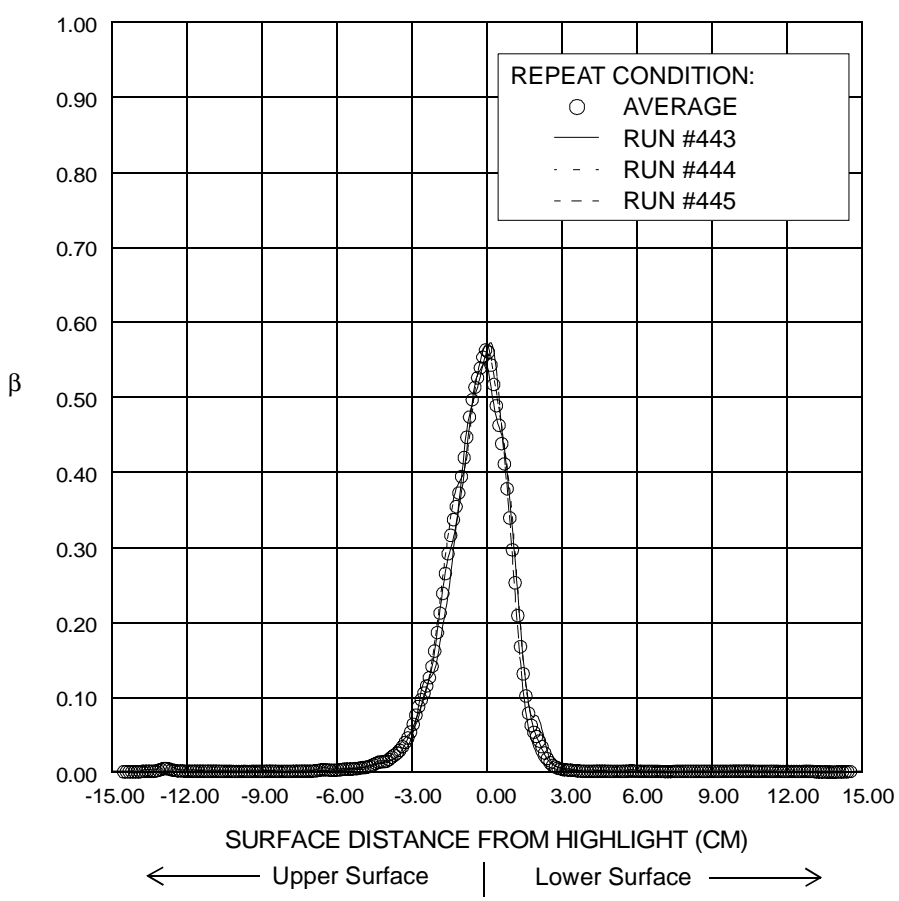

Figure 10: Experimental Collection Efficiency for the full scale modified 64A008 wing tip for angle-ofattack, $1^{\circ}$; airspeed, $75 \mathrm{~m} / \mathrm{s}$; static temperature, $7^{\circ}$ C; static pressure, $95840 \mathrm{~Pa}, \mathrm{MVD}, 21 \mu \mathrm{m}$.

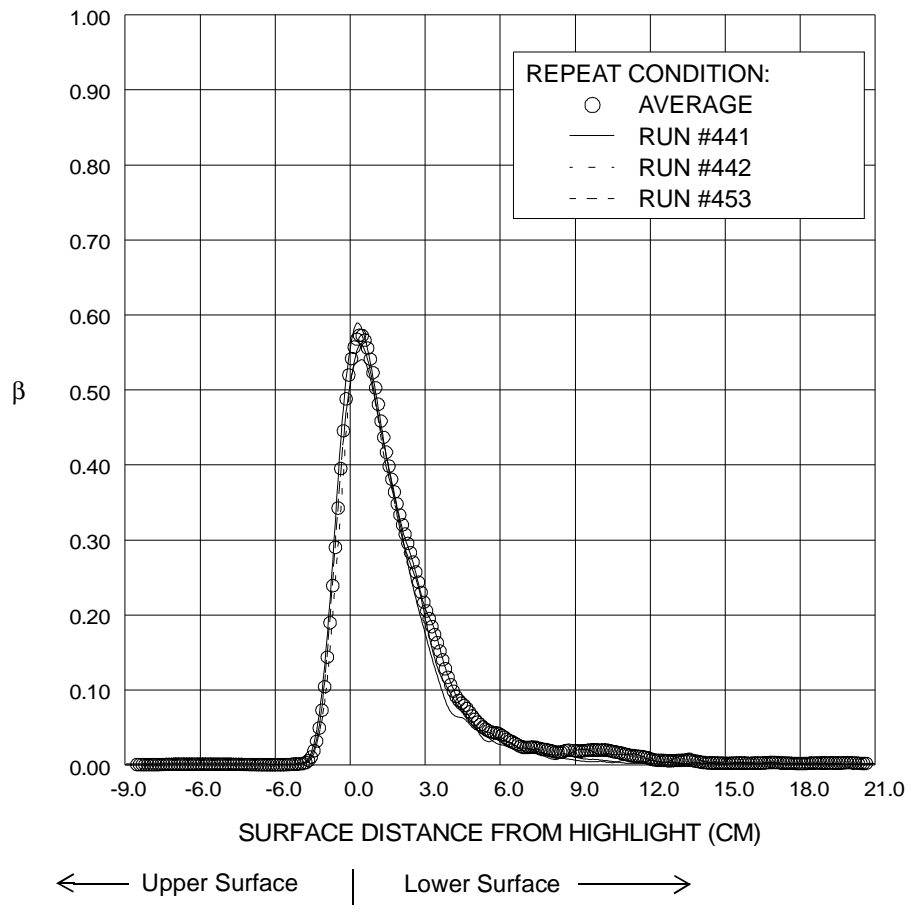

Figure 9: Experimental Collection Efficiency for the full scale modified 64A008 wing tip for angle-ofattack, $6^{\circ}$; airspeed, $75 \mathrm{~m} / \mathrm{s}$; static temperature, $7^{\circ}$ C; static pressure, $95840 \mathrm{~Pa}, \mathrm{MVD}, 21 \mu \mathrm{m}$.

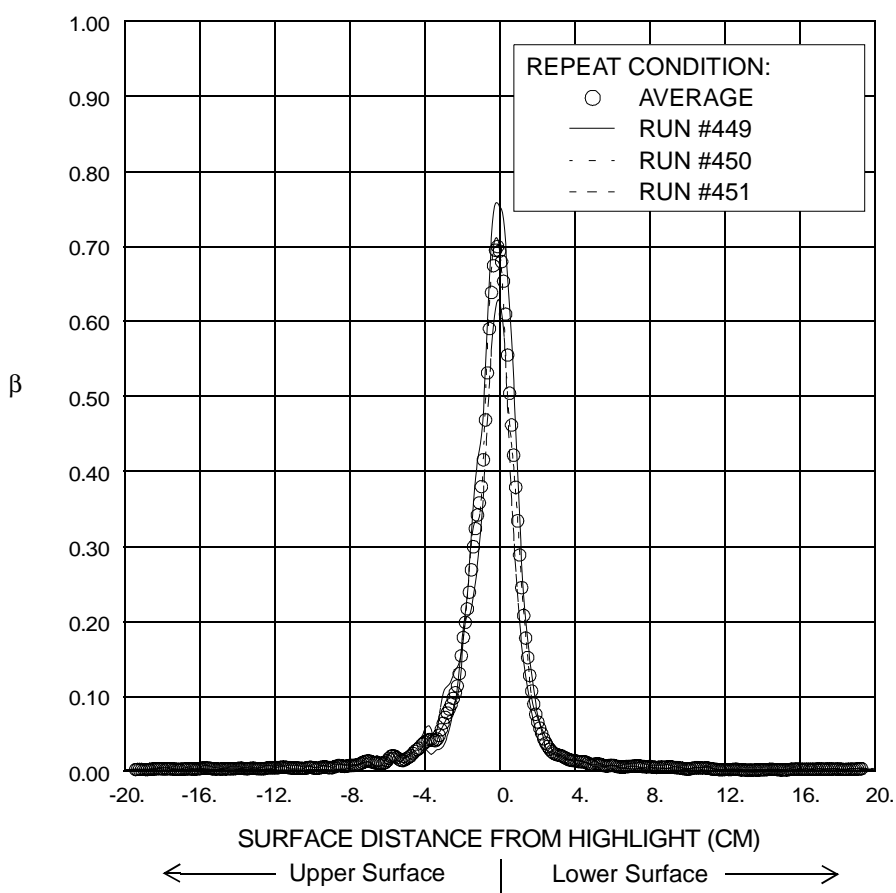

Figure 11: Experimental Collection Efficiency for the full scale modified 64A008 wing tip for angle-ofattack, $1^{\circ}$; airspeed, $75 \mathrm{~m} / \mathrm{s}$; static temperature, $7^{\circ}$ C; static pressure, $95840 \mathrm{~Pa}, \mathrm{MVD}, 92 \mu \mathrm{m}$. 


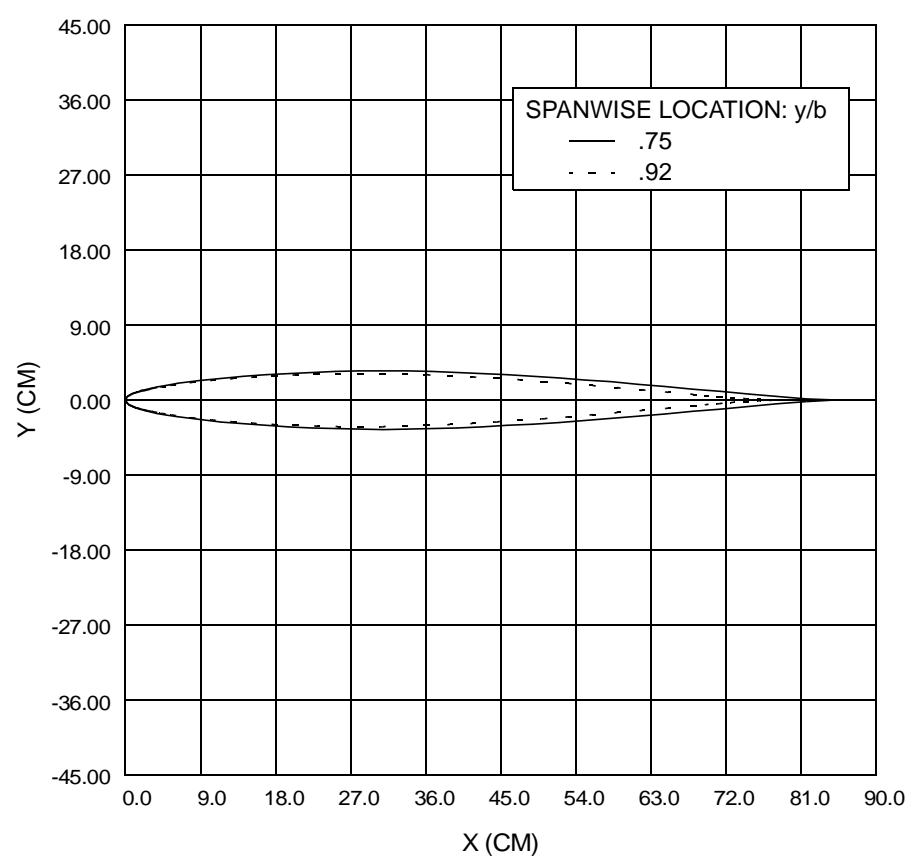

Figure 12: Wing profiles for the the swept NACA 64A008 wing tip.

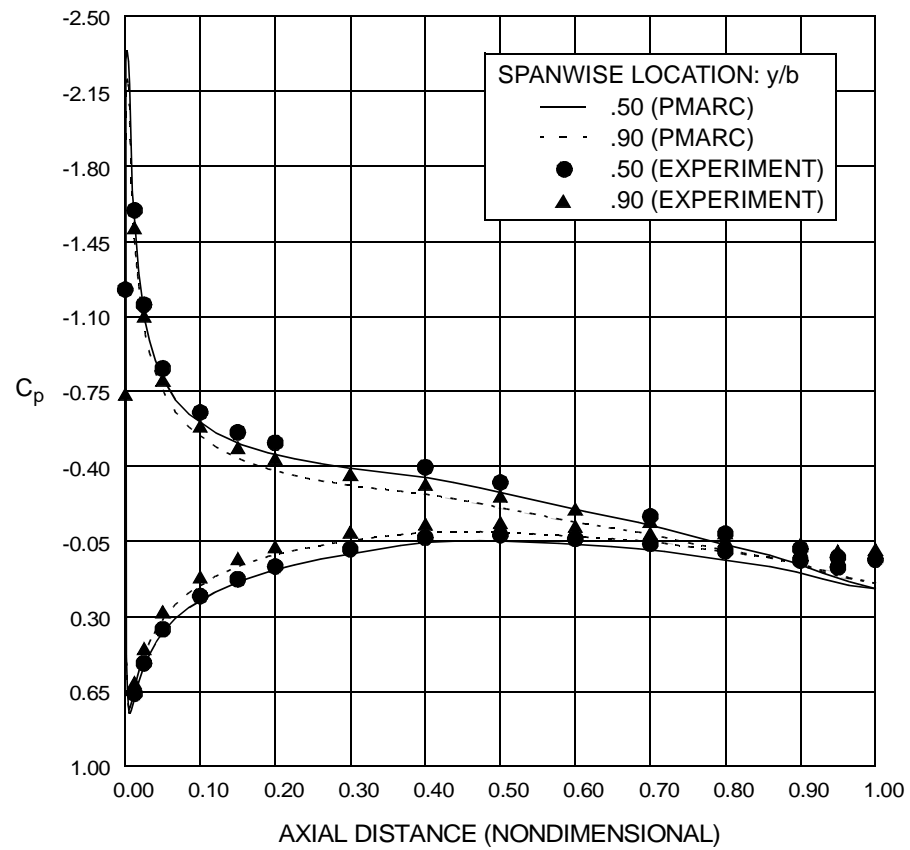

Figure 14: Comparison of experimental and analytical coefficient of pressure distribution for the swept NACA 64A008 wing tip for angle-of-attack, $6^{\circ}$; airspeed, $75 \mathrm{~m} / \mathrm{s}$; static temperature, $7^{\circ} \mathrm{C}$; static pressure, $95840 \mathrm{~Pa}$.

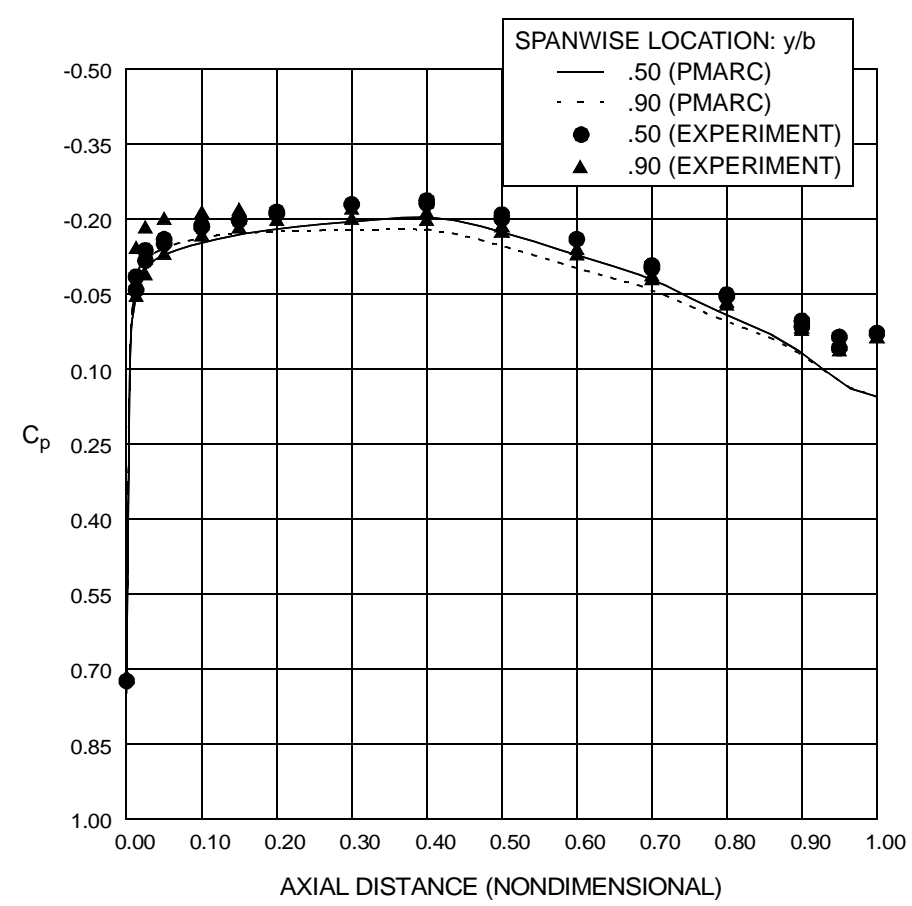

Figure 13: Comparison of experimental and analytical coefficient of pressure distribution for the swept NACA 64A008 wing tip for angle-of-attack, $0^{\circ}$; airspeed, $75 \mathrm{~m} / \mathrm{s}$; static temperature, $7^{\circ} \mathrm{C}$; static pressure, $95840 \mathrm{~Pa}$.

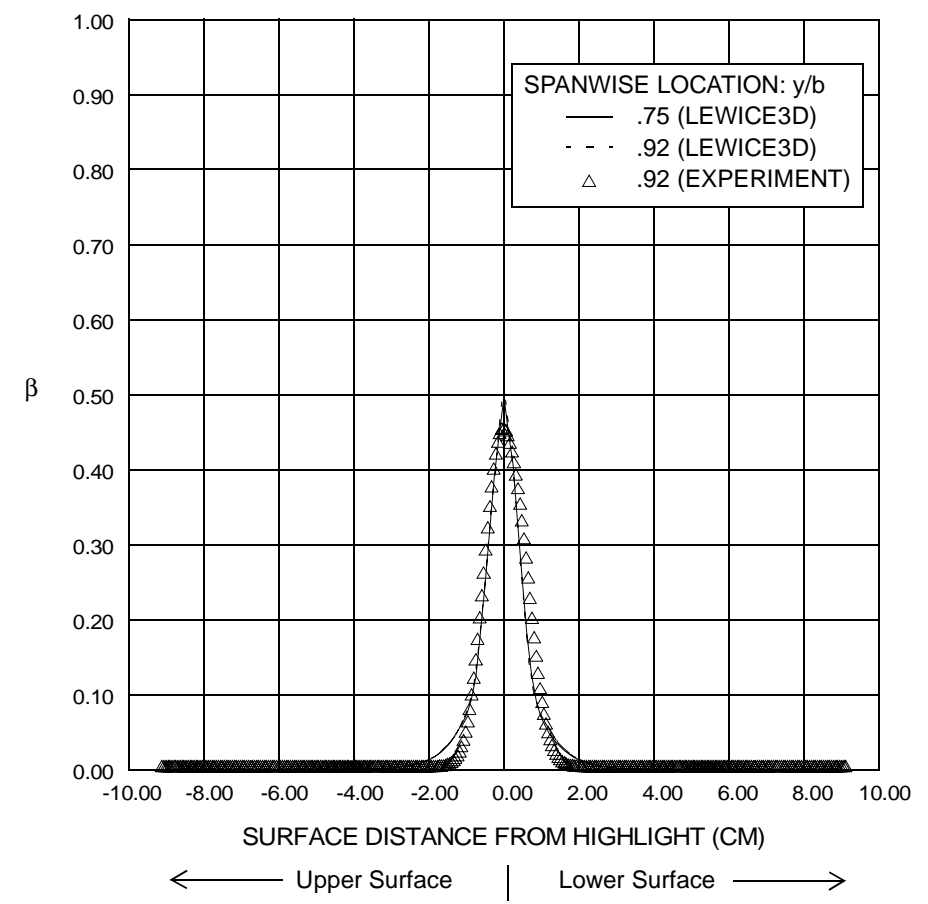

Figure 15: Experimental and analytical collection efficiency for the swept NACA 64A008 wing tip for angle-of-attack, $0^{\circ}$; airspeed, $75 \mathrm{~m} / \mathrm{s}$; static temperature, $7^{\circ} \mathrm{C}$; static pressure, $95840 \mathrm{~Pa}, \mathrm{MVD}$, $11 \mu \mathrm{m}$. 


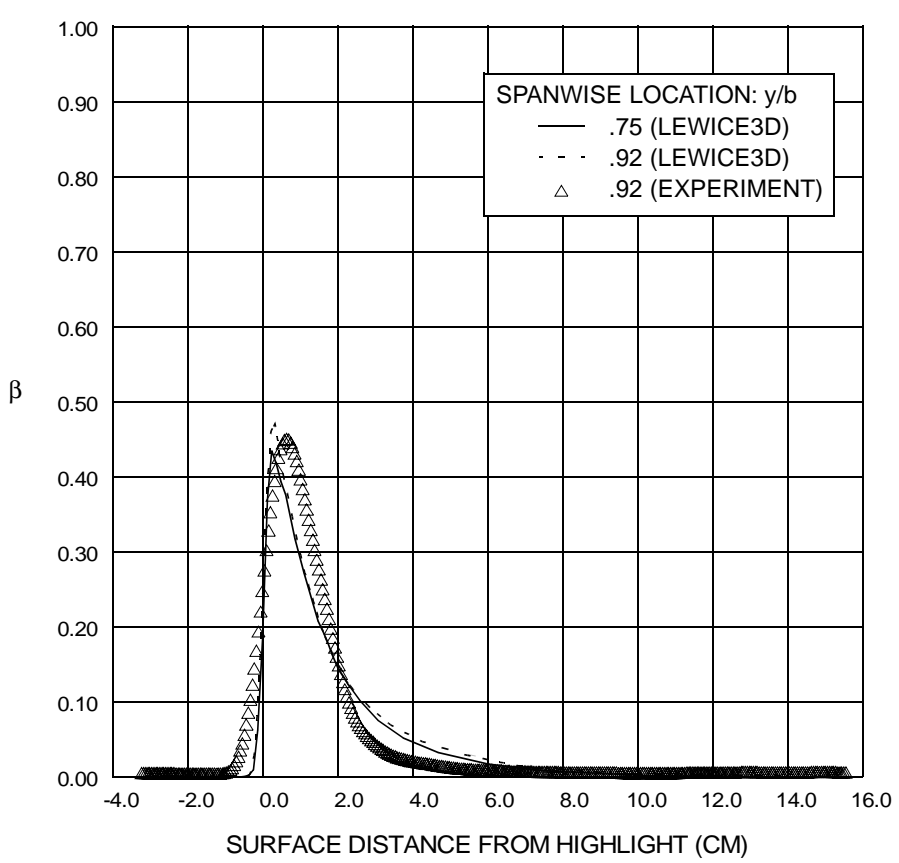

$\leftarrow$ Upper Surface $\quad$ Lower Surface $\longrightarrow$

Figure 16: Experimental and analytical collection efficiency for the swept NACA 64A008 wing tip for angle-of-attack, $6^{\circ}$; airspeed, $75 \mathrm{~m} / \mathrm{s}$; static temperature, $7^{\circ} \mathrm{C}$; static pressure, $95840 \mathrm{~Pa}, \mathrm{MVD}$, $11 \mu \mathrm{m}$.

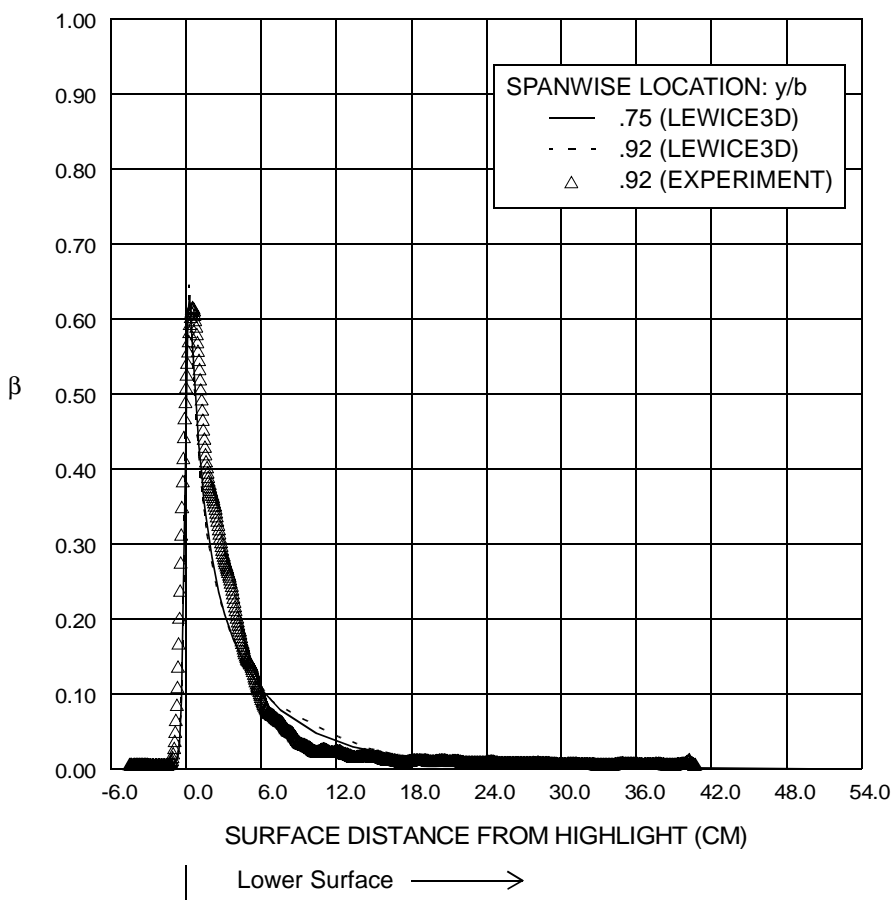

Figure 18: Experimental and analytical collection efficiency for the swept NACA 64A008 wing tip for angle-of-attack, $6^{\circ}$; airspeed, $75 \mathrm{~m} / \mathrm{s}$; static temperature, $7^{\circ} \mathrm{C}$; static pressure, $95840 \mathrm{~Pa}, \mathrm{MVD}$, $21 \mu \mathrm{m}$.

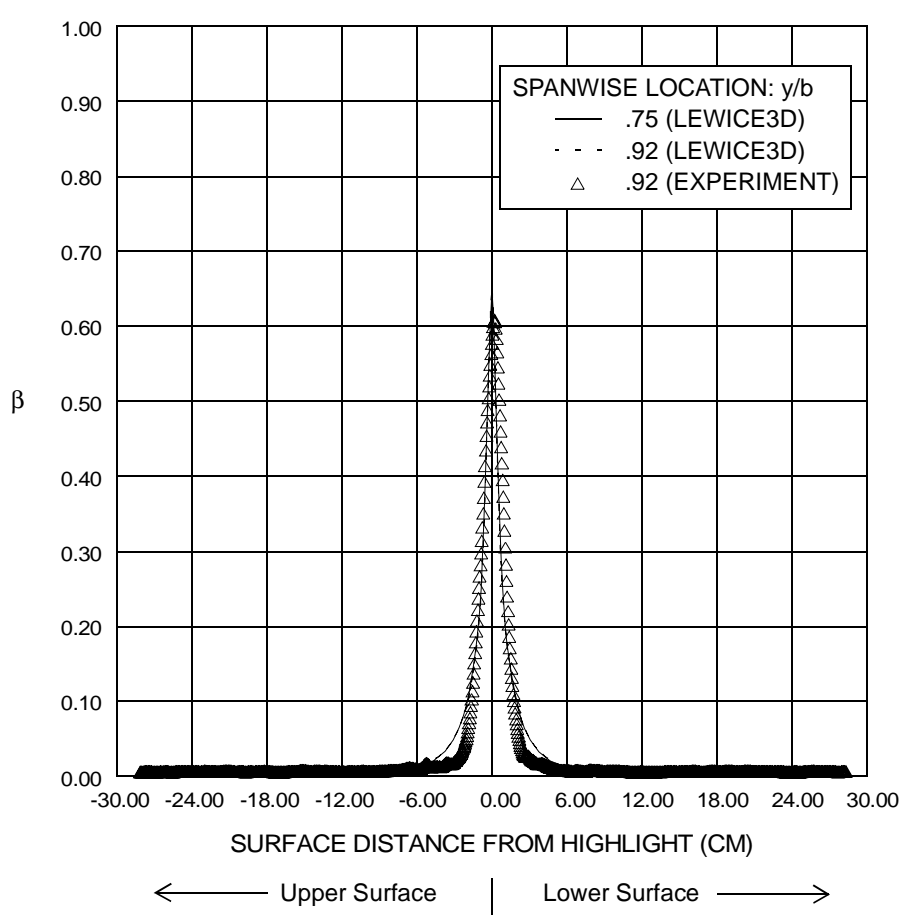

Figure 17: Experimental and analytical collection efficiency for the swept NACA 64A008 wing tip for angle-of-attack, $0^{\circ}$; airspeed, $75 \mathrm{~m} / \mathrm{s}$; static temperature, $7^{\circ} \mathrm{C}$; static pressure, $95840 \mathrm{~Pa}, \mathrm{MVD}$, $21 \mu \mathrm{m}$.

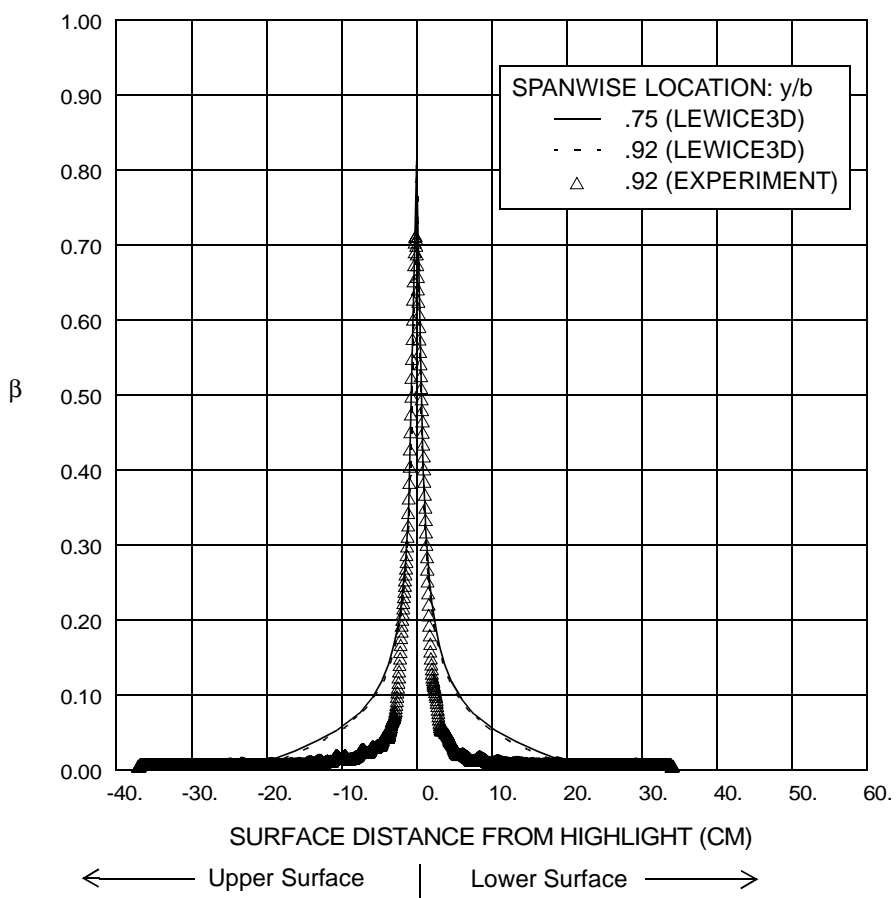

Figure 19: Experimental and analytical collection efficiency for the swept NACA 64A008 wing tip for angle-of-attack, $0^{\circ}$; airspeed, $75 \mathrm{~m} / \mathrm{s}$; static temperature, $7^{\circ} \mathrm{C}$; static pressure, $95840 \mathrm{~Pa}, \mathrm{MVD}$, $92 \mu \mathrm{m}$. 


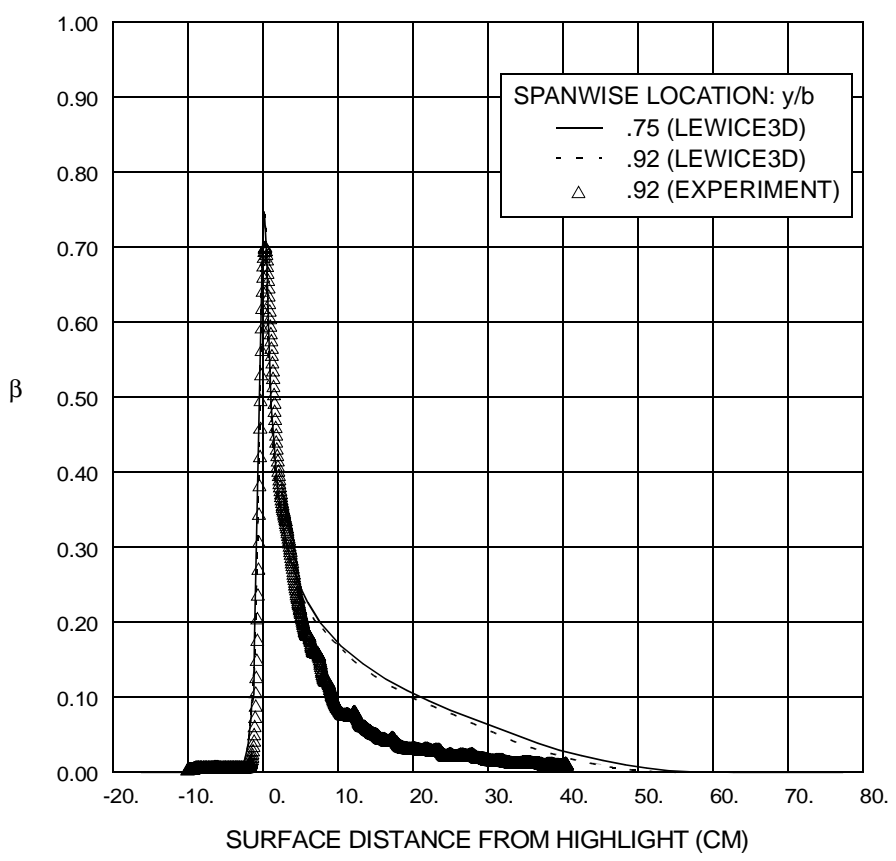

$\leftarrow$ Upper Surface $\quad$ Lower Surface $\longrightarrow$

Figure 20: Experimental and analytical collection efficiency for the swept NACA 64A008 wing tip for angle-of-attack, $6^{\circ}$; airspeed, $75 \mathrm{~m} / \mathrm{s}$; static temperature, $7^{\circ} \mathrm{C}$; static pressure, $95840 \mathrm{~Pa}, \mathrm{MVD}$, $92 \mu \mathrm{m}$.

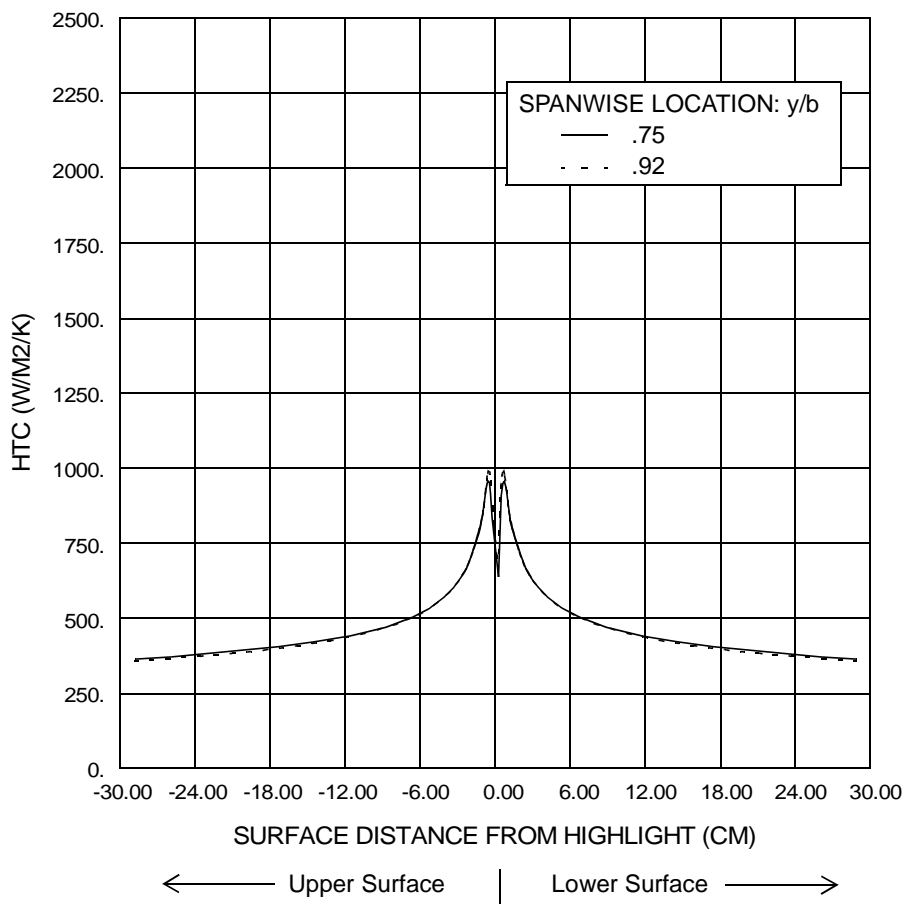

Figure 22: Theoretical heat transfer coefficient distribution for the swept NACA 64A008 wing tip for angle-of-attack, $0^{\circ}$. Icing Conditions: airspeed, 75 $\mathrm{m} / \mathrm{s}$; static temperature, $-9.3^{\circ} \mathrm{C}$; static pressure, $95840 \mathrm{~Pa}$.

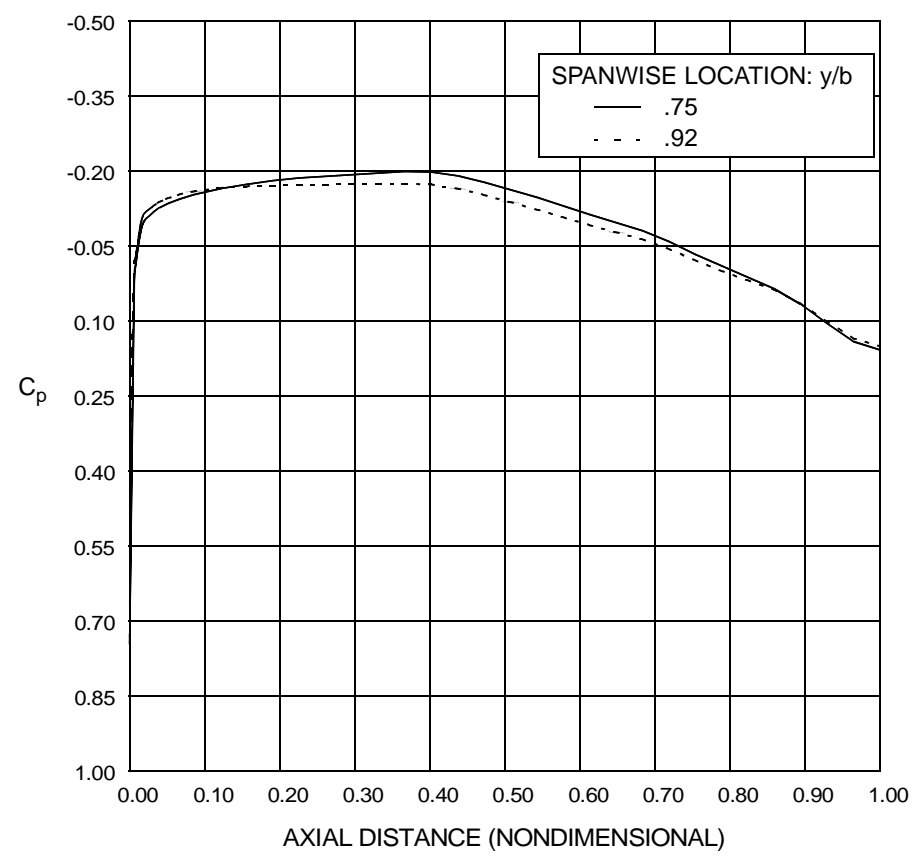

Figure 21: Theoretical coefficient of pressure distribution for the swept NACA 64A008 wing tip for angle-ofattack, $0^{\circ}$. Icing Conditions: airspeed, $75 \mathrm{~m} / \mathrm{s}$; static temperature, $-9.3^{\circ} \mathrm{C}$; static pressure, 95840 $\mathrm{Pa}$.

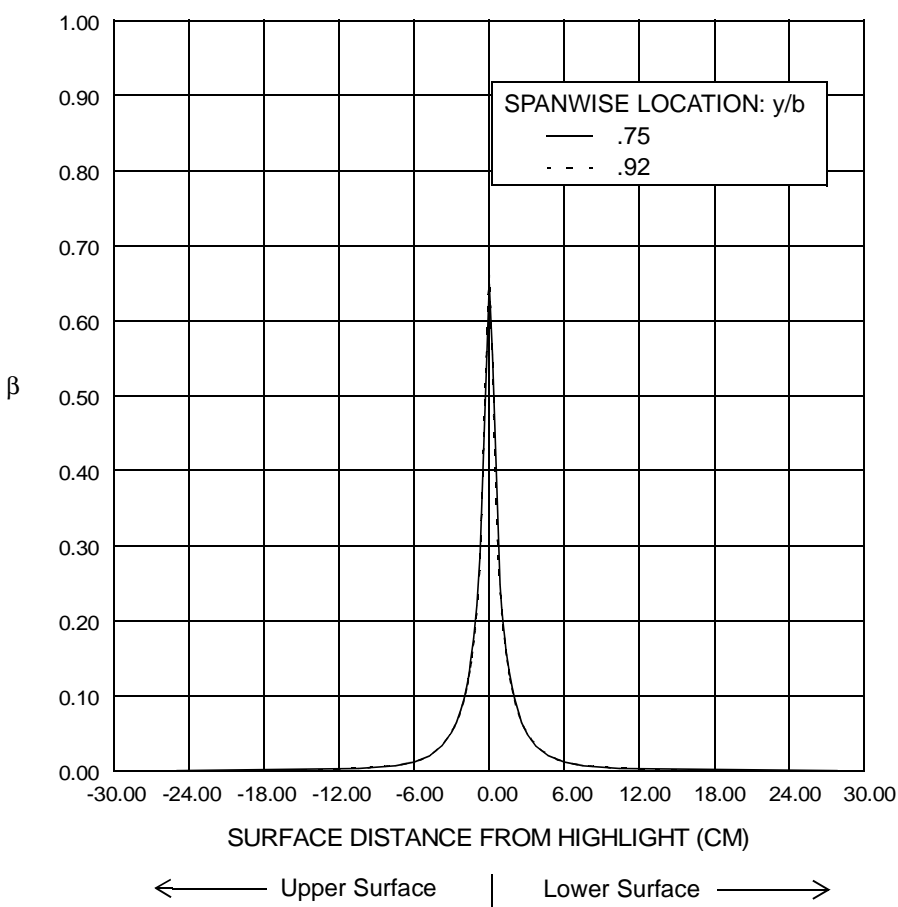

Figure 23: Theoretical collection efficiency for the swept NACA 64A008 wing tip for angle-of-attack, $0^{\circ}$. Icing Conditions: airspeed, $75 \mathrm{~m} / \mathrm{s}$; static temperature, $-9.3^{\circ} \mathrm{C}$; static pressure, $95840 \mathrm{~Pa}$; MVD, $21 \mu \mathrm{m}$. 


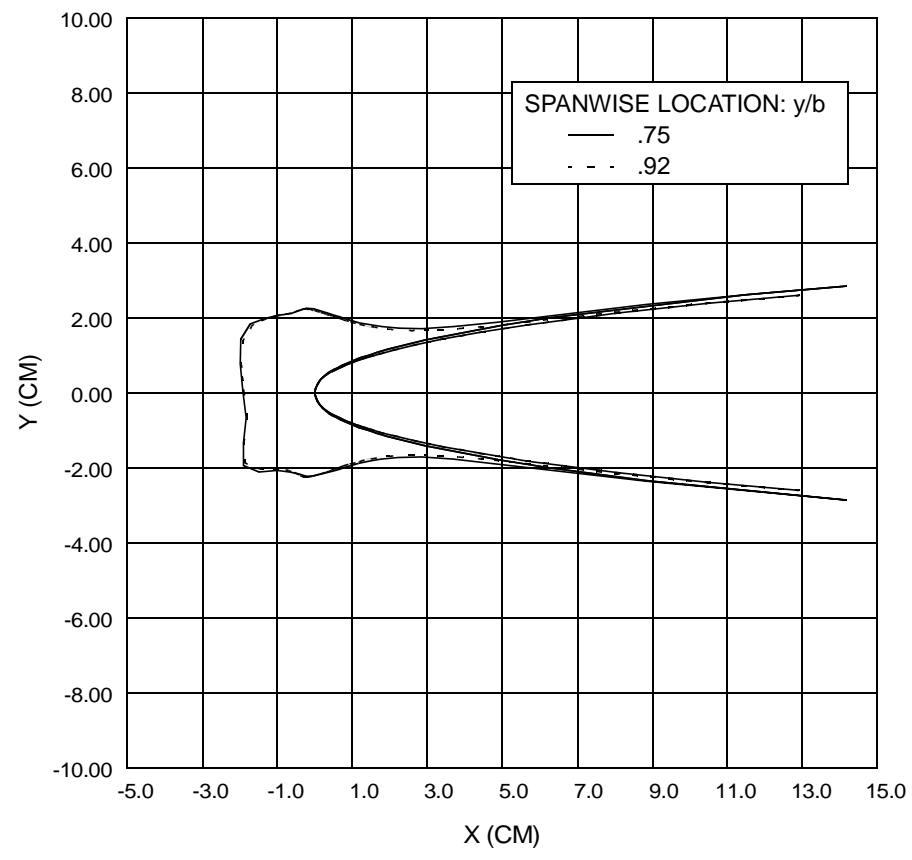

Figure 24: Theoretical ice shapes for the swept NACA $64 \mathrm{~A} 008$ wing tip for $0^{\circ}$ angle-of-attack. Icing conditions: airspeed, $75 \mathrm{~m} / \mathrm{s}$; icing time, 30 minutes; static temperature, $-9.3^{\circ} \mathrm{C}$; static pressure, 95840 $\mathrm{Pa}$; liquid water content, .695 g/m³

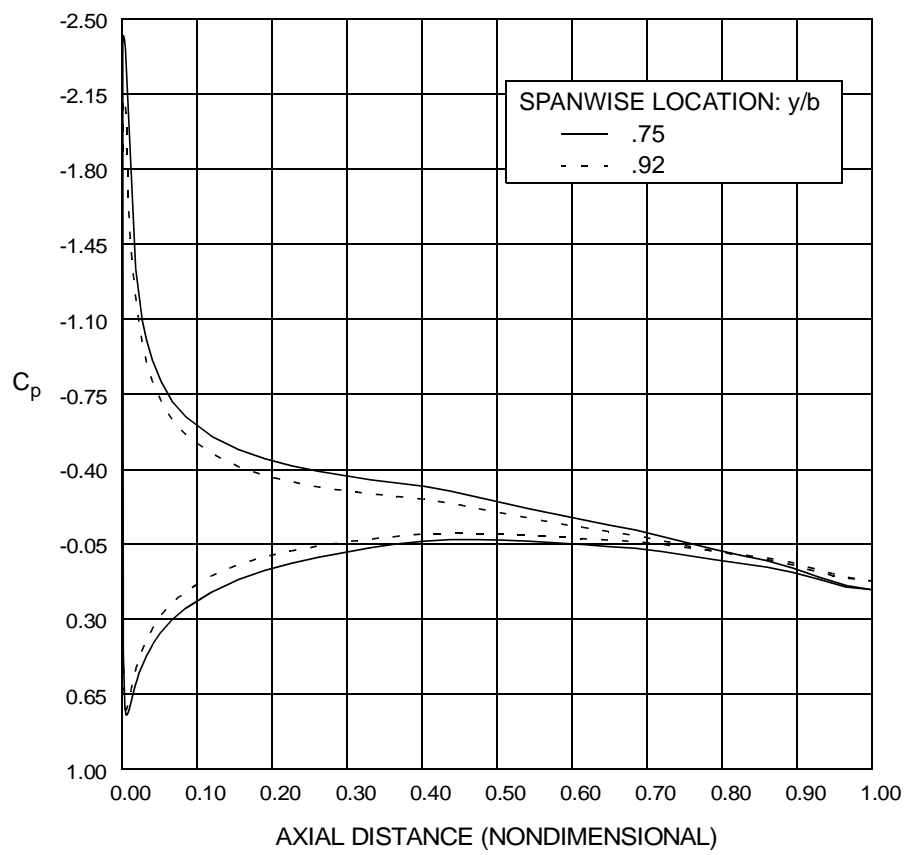

Figure 26: Theoretical coefficient of pressure distribution for the swept NACA 64A008 wing tip for angle-of-attack, $6^{\circ}$. Icing Conditions: airspeed, 75 $\mathrm{m} / \mathrm{s}$; static temperature, $-9.3^{\circ} \mathrm{C}$; static pressure, $95840 \mathrm{~Pa}$.

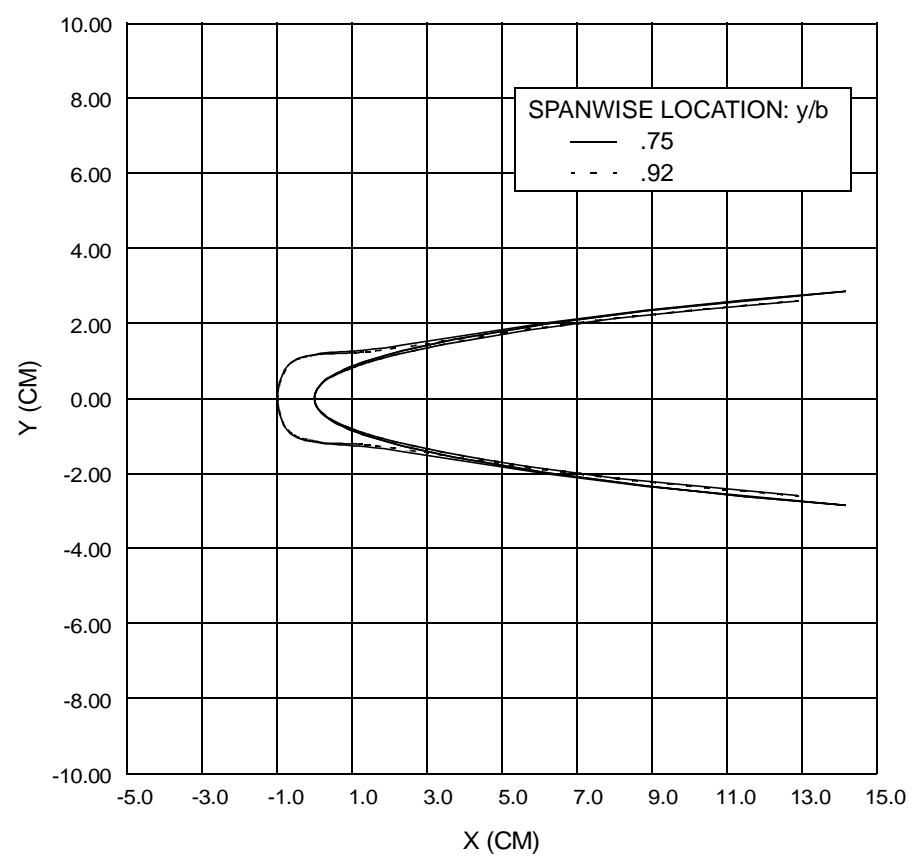

Figure 25: Theoretical ice shapes for the swept NACA 64A008 wing tip for $0^{\circ}$ angle-of-attack. Icing conditions: airspeed, $75 \mathrm{~m} / \mathrm{s}$; icing time, 30 minutes; static temperature, $-29.9^{\circ} \mathrm{C}$; static pressure, $95840 \mathrm{~Pa}$; liquid water content, .2 $\mathrm{g} / \mathrm{m}^{3}$; MVD, 21 $\mu \mathrm{m}$.

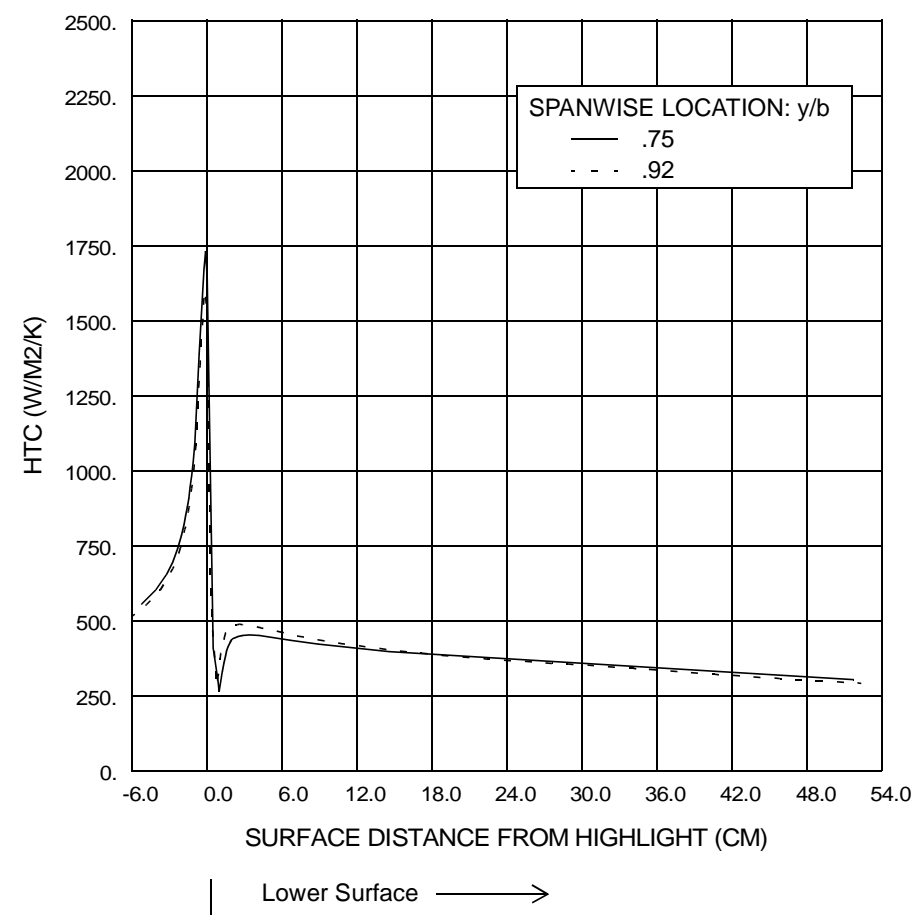

Figure 27: Theoretical heat transfer coefficient distribution for the swept NACA 64A008 wing tip for angle-ofattack, $6^{\circ}$. Icing Conditions: airspeed, $75 \mathrm{~m} / \mathrm{s}$; static temperature, $-9.3^{\circ} \mathrm{C}$; static pressure, 95840 $\mathrm{Pa}$. 


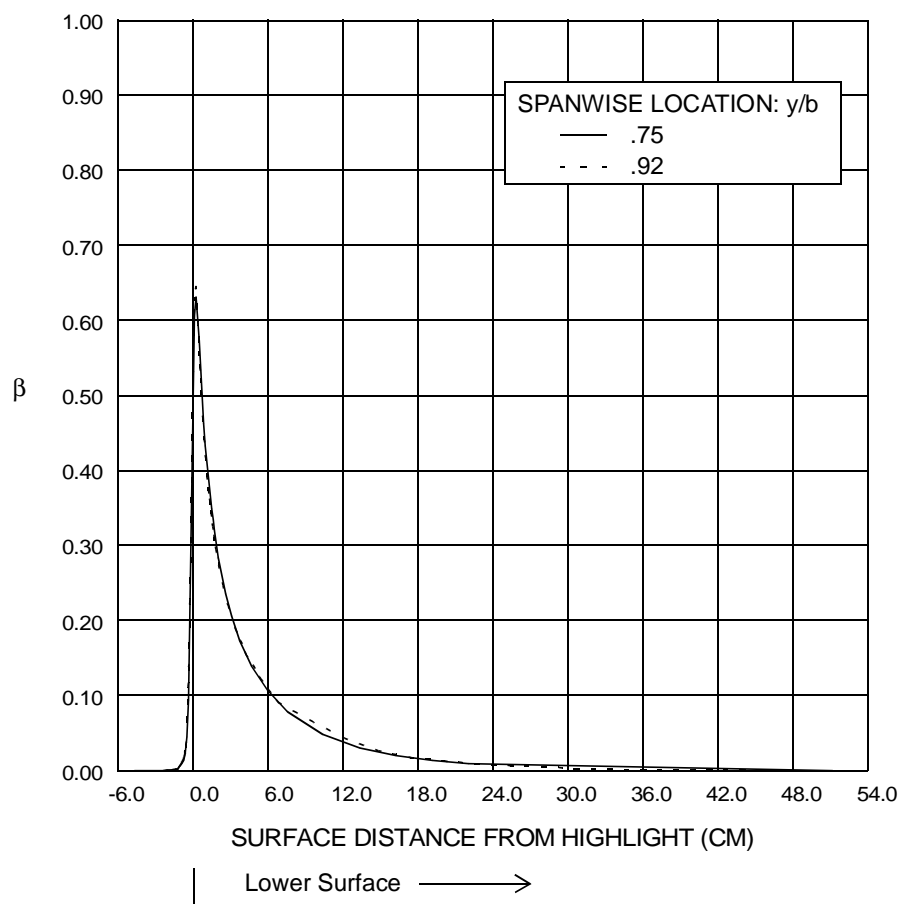

Figure 28: Theoretical collection efficiency for the swept NACA 64A008 wing tip for angle-of-attack, $6^{\circ}$. Icing Conditions: airspeed, $75 \mathrm{~m} / \mathrm{s}$; static temperature, $-9.3^{\circ} \mathrm{C}$; static pressure, $95840 \mathrm{~Pa}$; MVD, $21 \mu \mathrm{m}$.

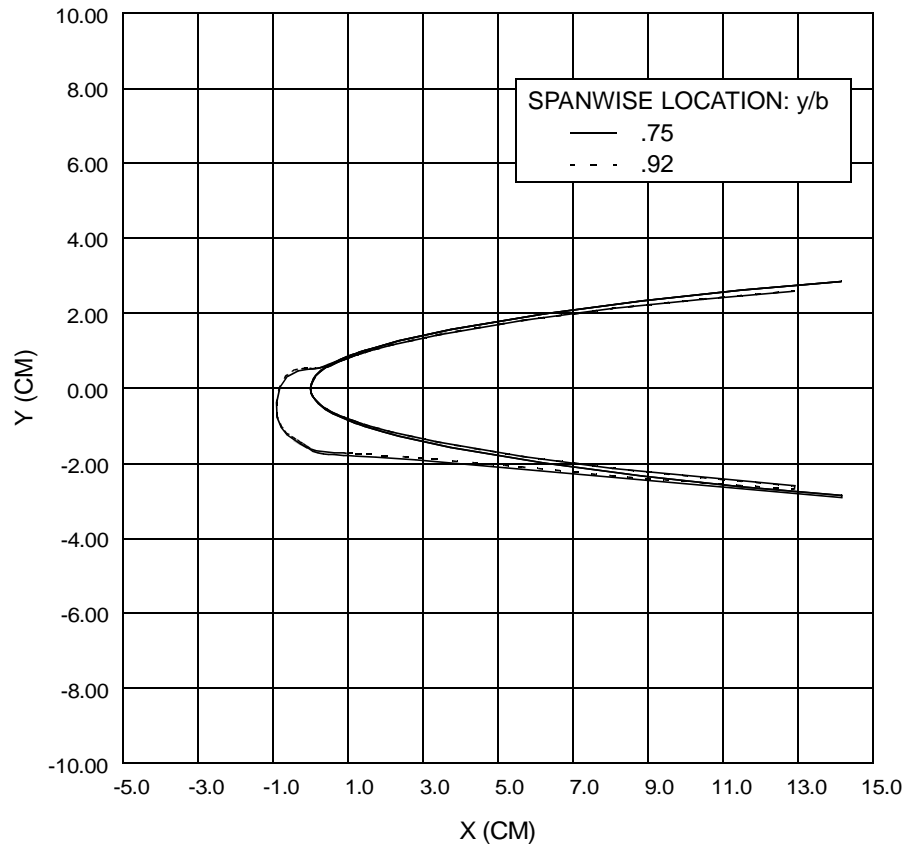

Figure 30: Theoretical ice shapes for the swept NACA 64A008 wing tip for $6^{\circ}$ angle-of-attack. Icing conditions: airspeed, $75 \mathrm{~m} / \mathrm{s}$; icing time, 30 minutes; static temperature, $-29.9^{\circ} \mathrm{C}$; static pressure, $95840 \mathrm{~Pa}$; liquid water content, . $2 \mathrm{~g} / \mathrm{m}^{3}$; MVD, 21 $\mu \mathrm{m}$.

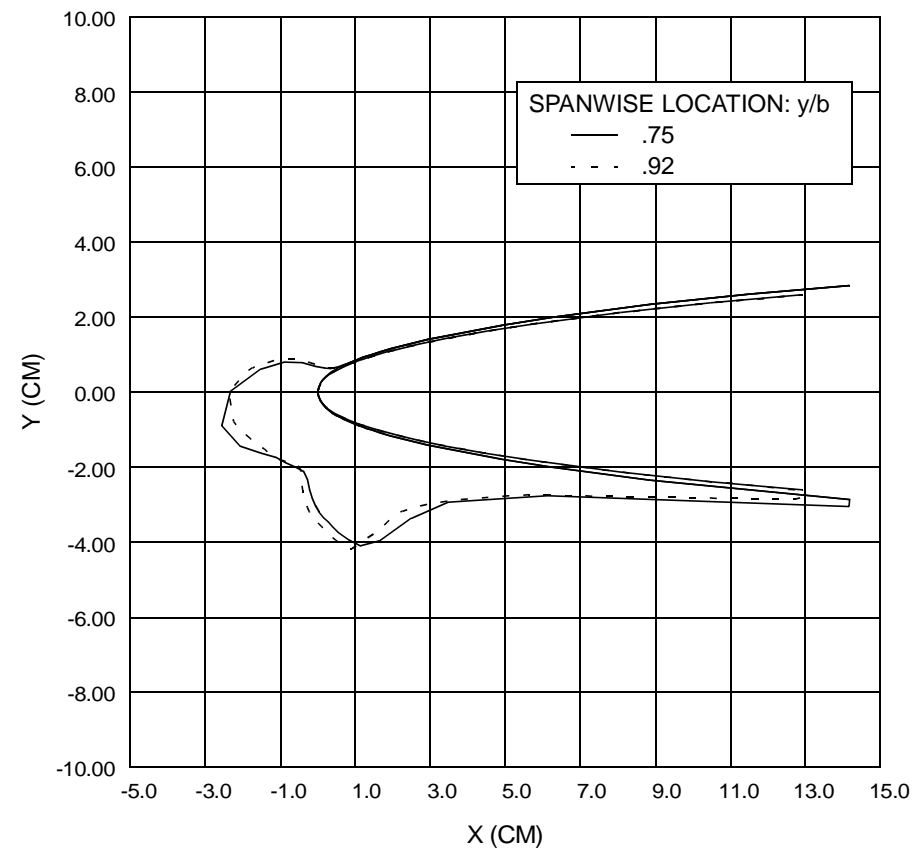

Figure 29: Theoretical ice shapes for the swept NACA $64 \mathrm{~A} 008$ wing tip for $6^{\circ}$ angle-of-attack. Icing conditions: airspeed, $75 \mathrm{~m} / \mathrm{s}$; icing time, 30 minutes; static temperature, $-9.3^{\circ} \mathrm{C}$; static pressure, 95840 $\mathrm{Pa}$; liquid water content, .695 g/m³

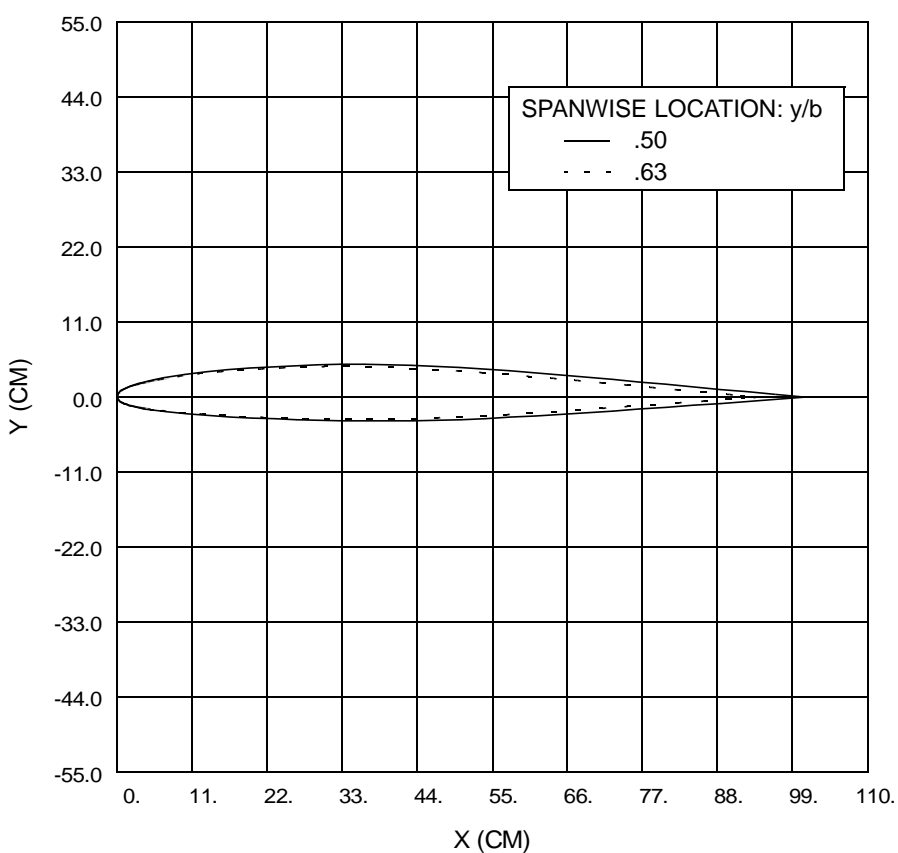

Figure 31: Wing profiles for the full scale horizontal tail. 


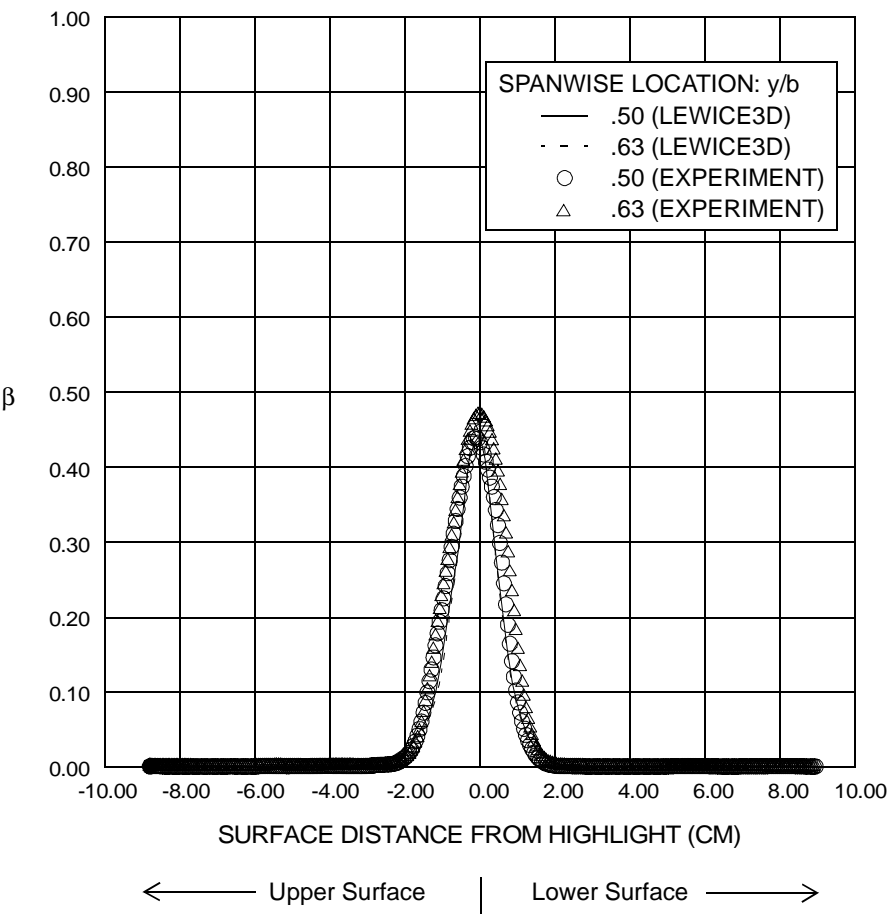

Figure 32: Experimental and analytical collection efficiency for the full scale horizontal tail for angle-ofattack, $1^{\circ}$; airspeed, $75 \mathrm{~m} / \mathrm{s}$; static temperature, $7^{\circ}$ C; static pressure, $95840 \mathrm{~Pa}, \mathrm{MVD}, 11 \mu \mathrm{m}$.

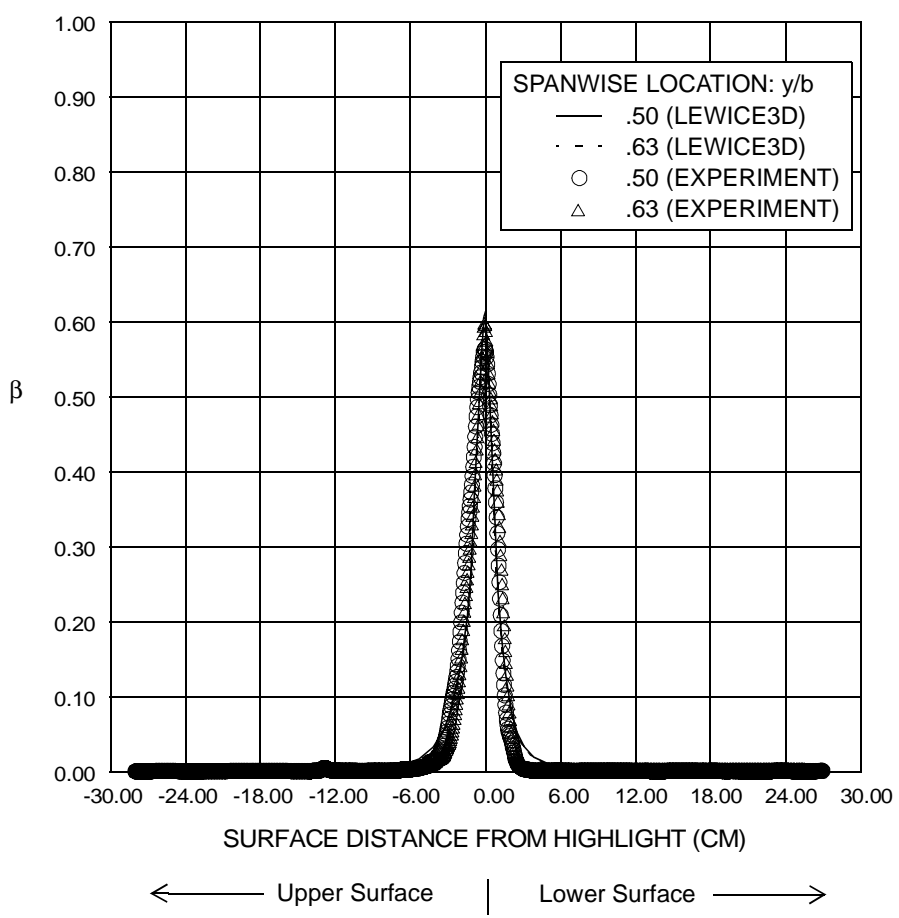

Figure 34: Experimental and analytical collection efficiency for the full scale horizontal tail for angle-ofattack, $1^{\circ}$; airspeed, $75 \mathrm{~m} / \mathrm{s}$; static temperature, $7^{\circ}$ C; static pressure, $95840 \mathrm{~Pa}, \mathrm{MVD}, 21 \mu \mathrm{m}$.

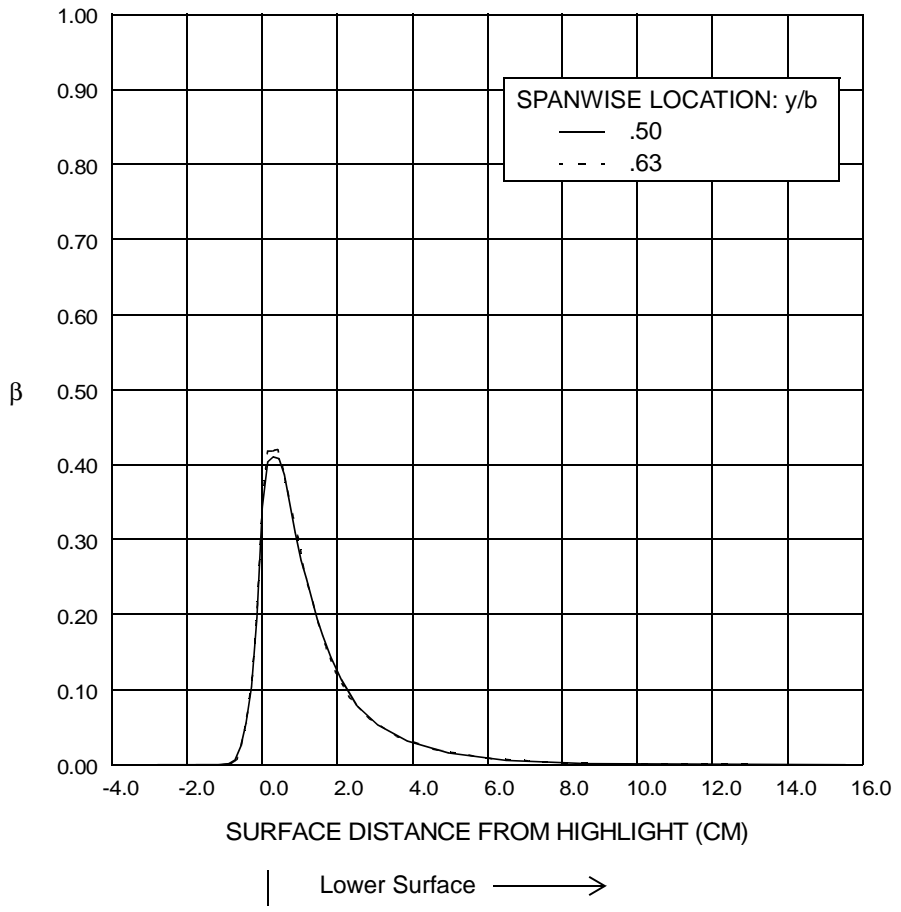

Figure 33: Analytical collection efficiency for the full scale horizontal tail for angle-of-attack, $6^{\circ}$; airspeed, $75 \mathrm{~m} / \mathrm{s}$; static temperature, $7^{\circ} \mathrm{C}$; static pressure, $95840 \mathrm{~Pa}, \mathrm{MVD}, 11 \mu \mathrm{m}$.

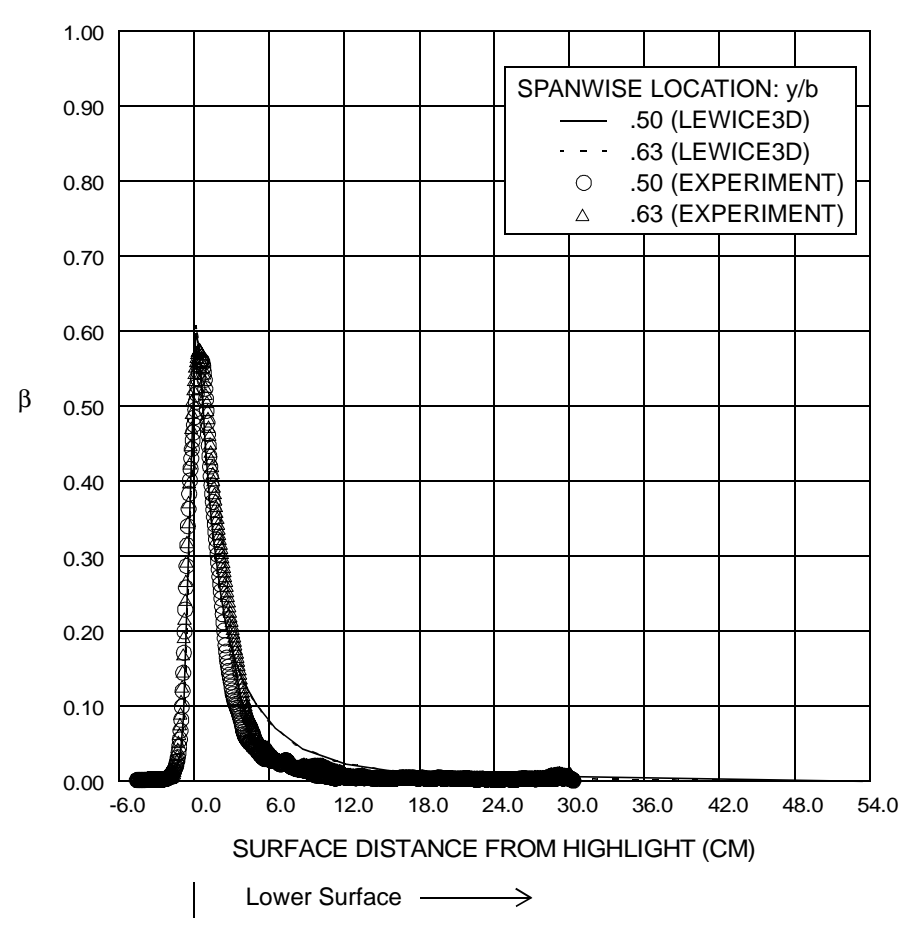

Figure 35: Experimental and analytical collection efficiency for the full scale horizontal tail for angle-ofattack, $6^{\circ}$; airspeed, $75 \mathrm{~m} / \mathrm{s}$; static temperature, $7^{\circ}$ C; static pressure, $95840 \mathrm{~Pa}, \mathrm{MVD}, 21 \mu \mathrm{m}$. 


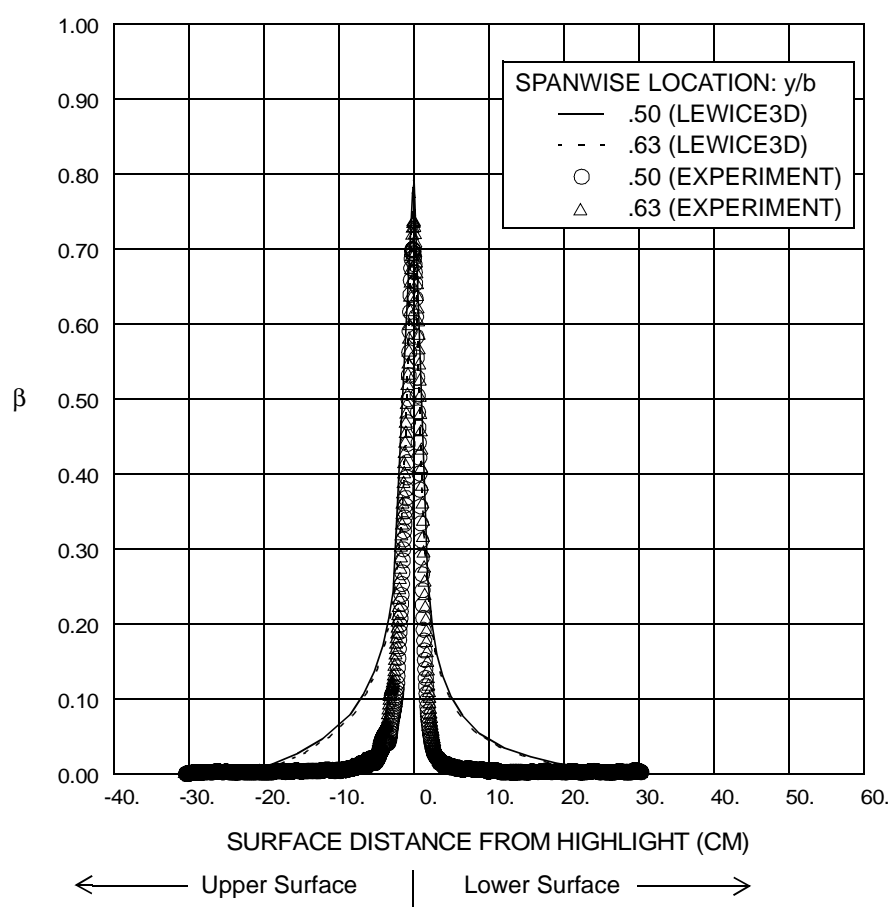

Figure 36: Experimental and analytical collection efficiency for the full scale horizontal tail for angle-ofattack, $1^{\circ}$; airspeed, $75 \mathrm{~m} / \mathrm{s}$; static temperature, $7^{\circ}$ C; static pressure, $95840 \mathrm{~Pa}, \mathrm{MVD}, 92 \mu \mathrm{m}$

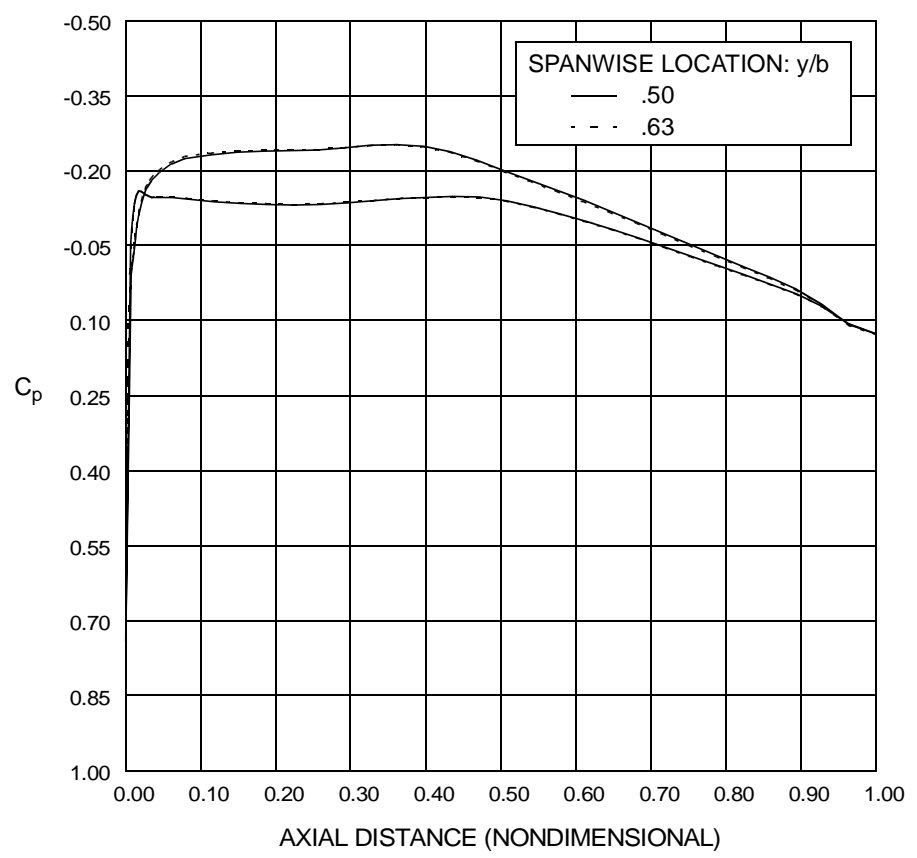

Figure 38: Theoretical coefficient of pressure distribution for the full scale horizontal tail for angle-of-attack, $1^{\circ}$. Icing Conditions: airspeed, $75 \mathrm{~m} / \mathrm{s}$; static temperature, $-9.3^{\circ} \mathrm{C}$; static pressure, $95840 \mathrm{~Pa}$.

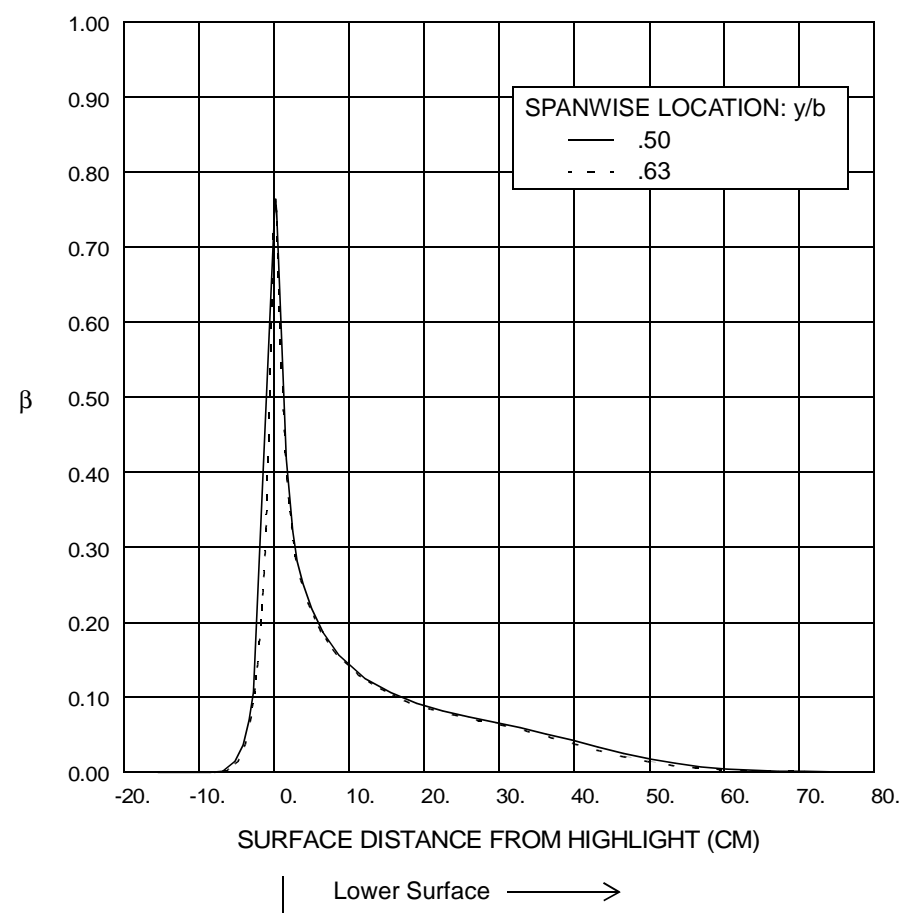

Figure 37: Analytical collection efficiency for the full scale horizontal tail for angle-of-attack, $6^{\circ}$; airspeed, 75 $\mathrm{m} / \mathrm{s}$; static temperature, $7^{\circ} \mathrm{C}$; static pressure, $95840 \mathrm{~Pa}, \mathrm{MVD}, 92 \mu \mathrm{m}$

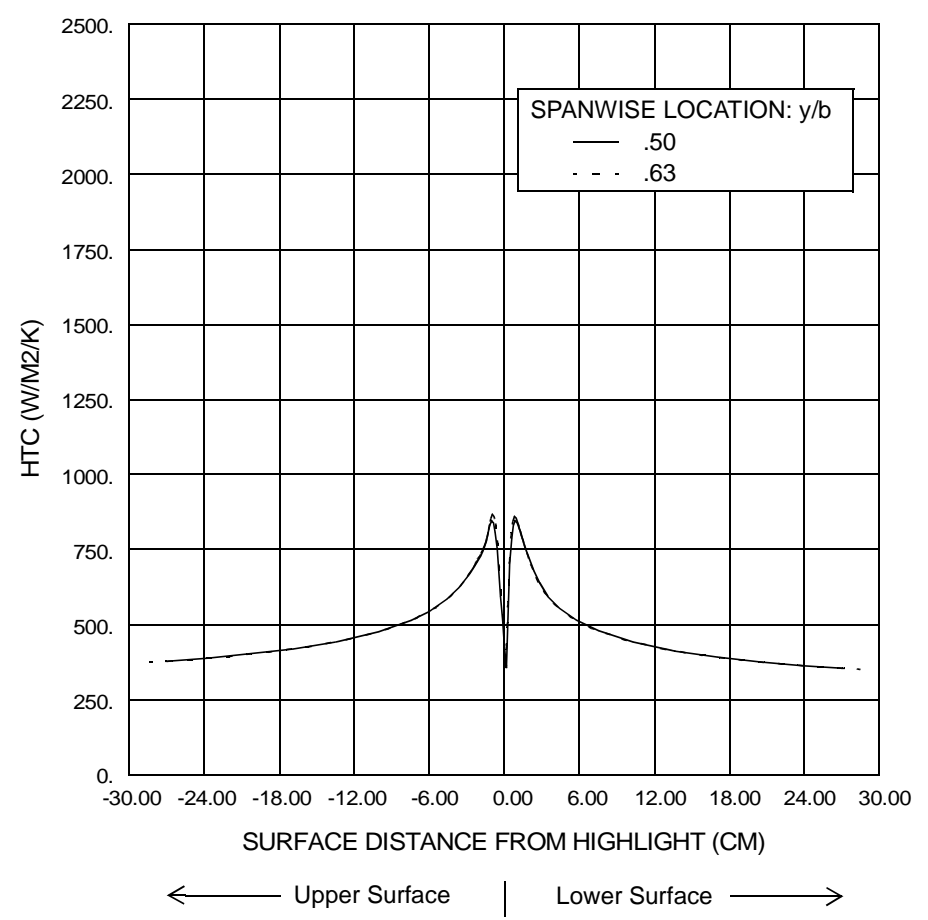

Figure 39: Theoretical heat transfer coefficient distribution for the full scale horizontal tail for angle-ofattack, $1^{\circ}$. Icing Conditions: airspeed, $75 \mathrm{~m} / \mathrm{s}$; static temperature, $-9.3^{\circ} \mathrm{C}$; static pressure, 95840 $\mathrm{Pa}$. 


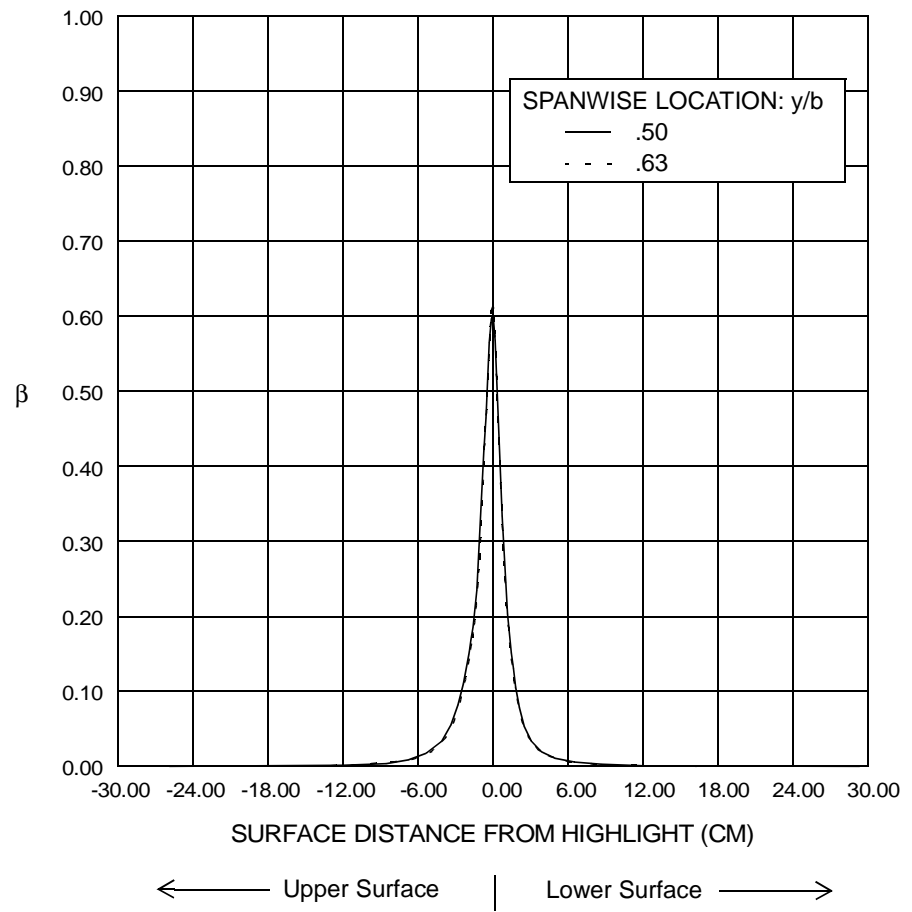

Figure 40: Theoretical collection efficiency for the full scale horizontal tail for angle-of-attack, $1^{\circ}$. Icing Conditions: airspeed, $75 \mathrm{~m} / \mathrm{s}$; static temperature, $-9.3^{\circ} \mathrm{C}$; static pressure, $95840 \mathrm{~Pa}$; MVD, $21 \mu \mathrm{m}$.

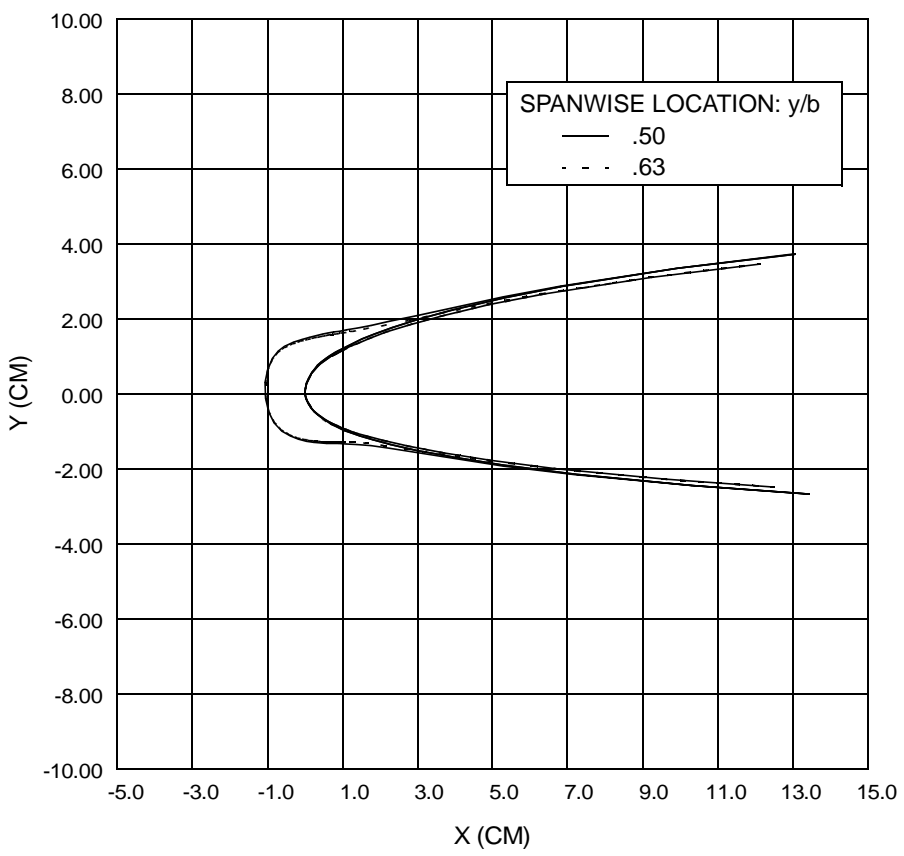

Figure 42: Theoretical ice shapes for the full scale horizontal tail for $1^{\circ}$ angle-of-attack. Icing conditions: airspeed, $75 \mathrm{~m} / \mathrm{s}$; icing time, 30 minutes; static temperature, $-29.9^{\circ} \mathrm{C}$; static pressure, $95840 \mathrm{~Pa}$; liquid water content, . $2 \mathrm{~g} / \mathrm{m}^{3}$; MVD, $21 \mu \mathrm{m}$.

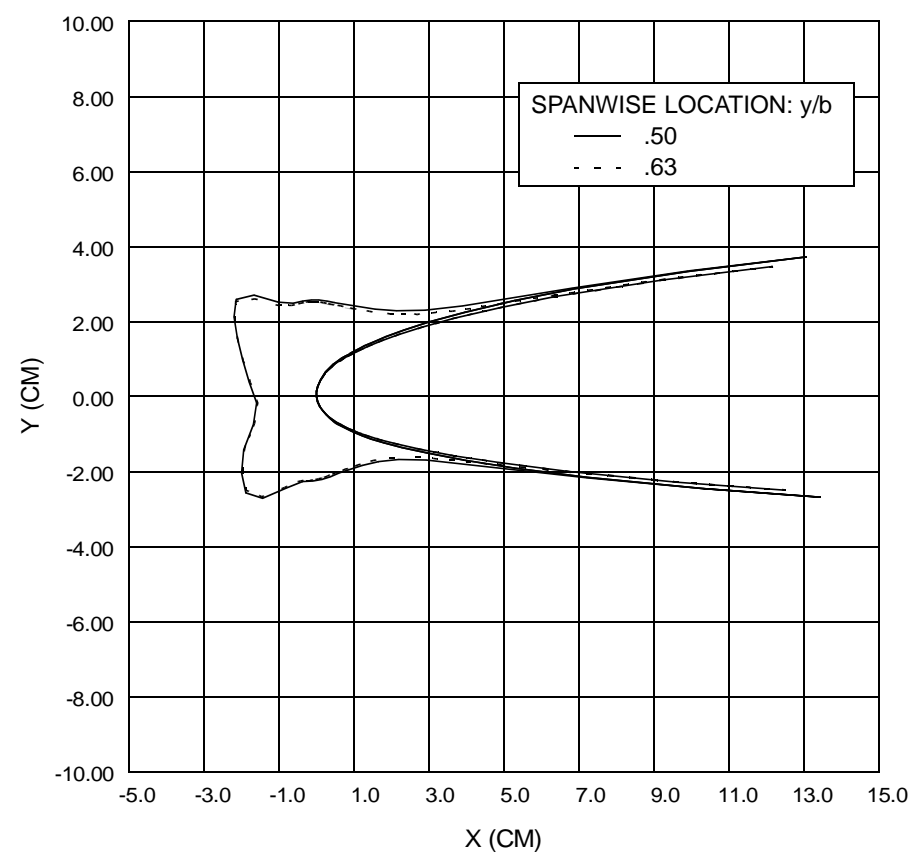

Figure 41: Theoretical ice shapes for the full scale horizontal tail for $1^{\circ}$ angle-of-attack. Icing conditions: airspeed, $75 \mathrm{~m} / \mathrm{s}$; icing time, 30 minutes; static temperature, $-9.3^{\circ} \mathrm{C}$; static pressure, $95840 \mathrm{~Pa}$; liquid water content, .695 g/m³; MVD, $21 \mu \mathrm{m}$.

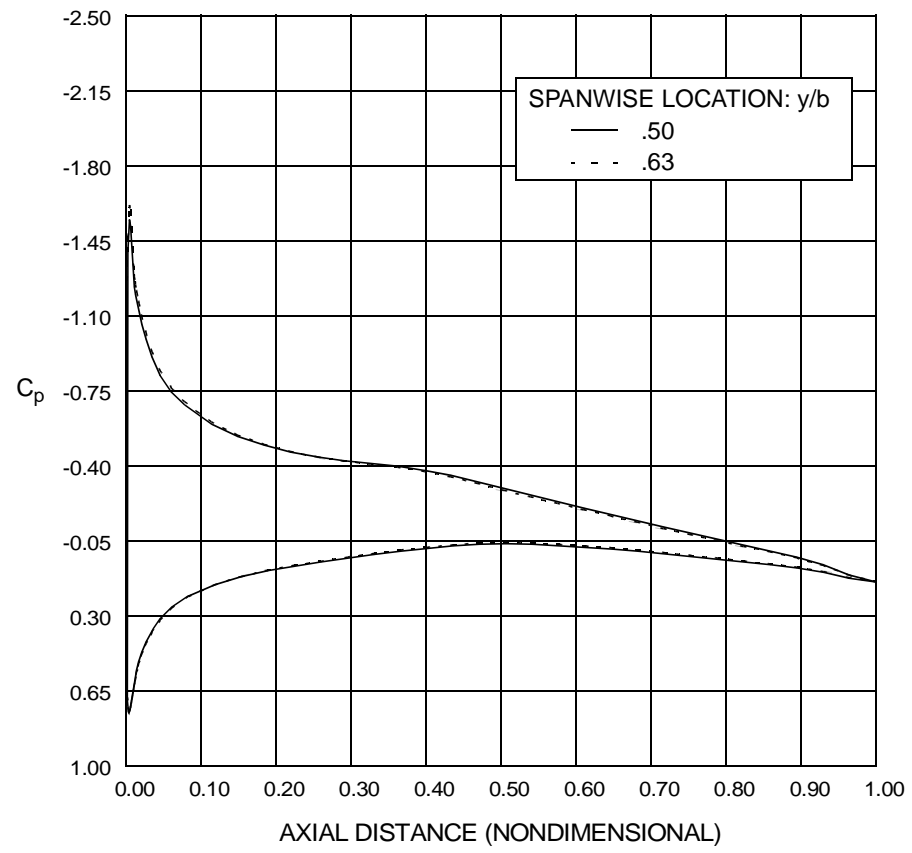

Figure 43: Theoretical coefficient of pressure distribution for the full scale horizontal tail for angle-of-attack, $6^{\circ}$. Icing Conditions: airspeed, $75 \mathrm{~m} / \mathrm{s}$; static temperature, $-9.3^{\circ} \mathrm{C}$; static pressure, $95840 \mathrm{~Pa}$. 


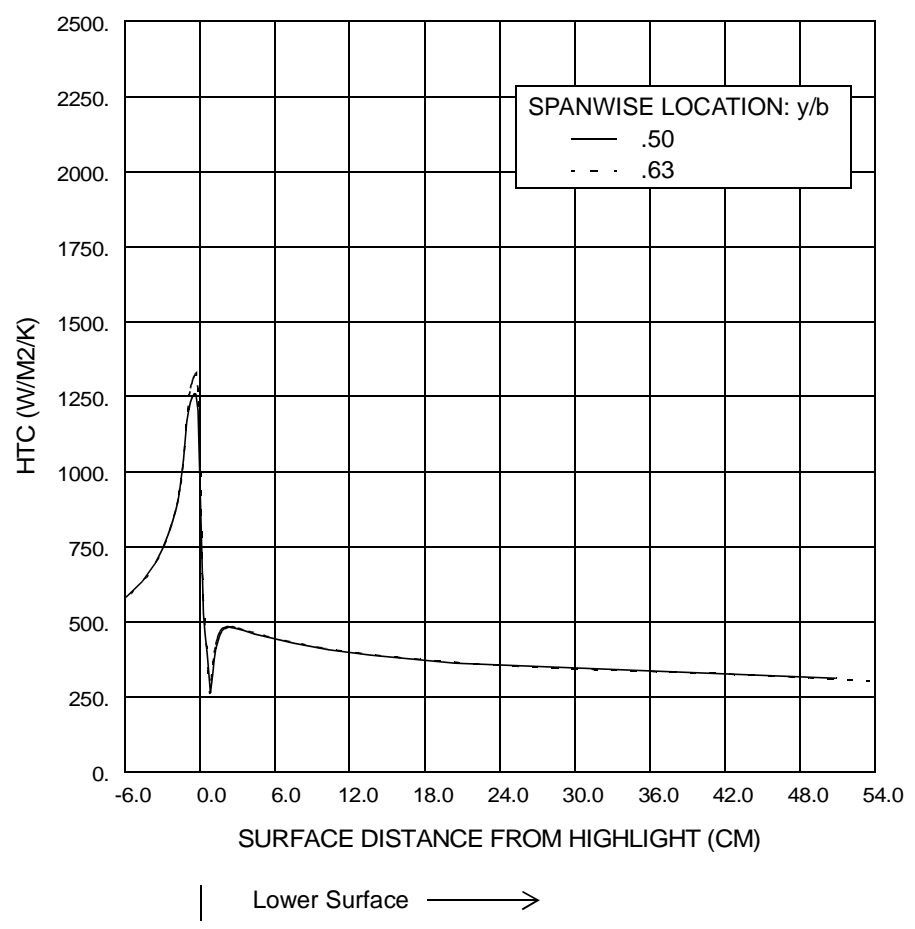

Figure 44: Theoretical heat transfer coefficient distribution for the full scale horizontal tail for angle-ofattack, $6^{\circ}$. Icing Conditions: airspeed, $75 \mathrm{~m} / \mathrm{s}$; static temperature, $-9.3^{\circ} \mathrm{C}$; static pressure, 95840 $\mathrm{Pa}$.

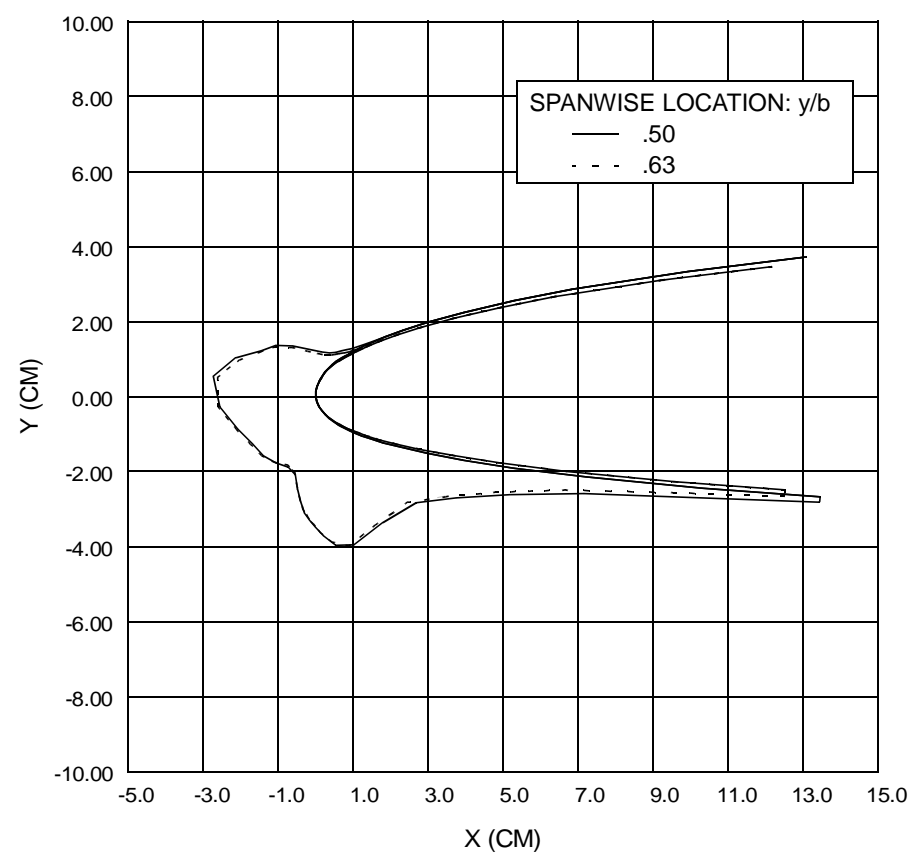

Figure 46: Theoretical ice shapes for the full scale horizontal tail for $6^{\circ}$ angle-of-attack. Icing conditions: airspeed, $75 \mathrm{~m} / \mathrm{s}$; icing time, 30 minutes; static temperature, $-9.3^{\circ} \mathrm{C}$; static pressure, $95840 \mathrm{~Pa}$; liquid water content, .695 $\mathrm{g} / \mathrm{m}^{3}$; MVD, $21 \mu \mathrm{m}$.

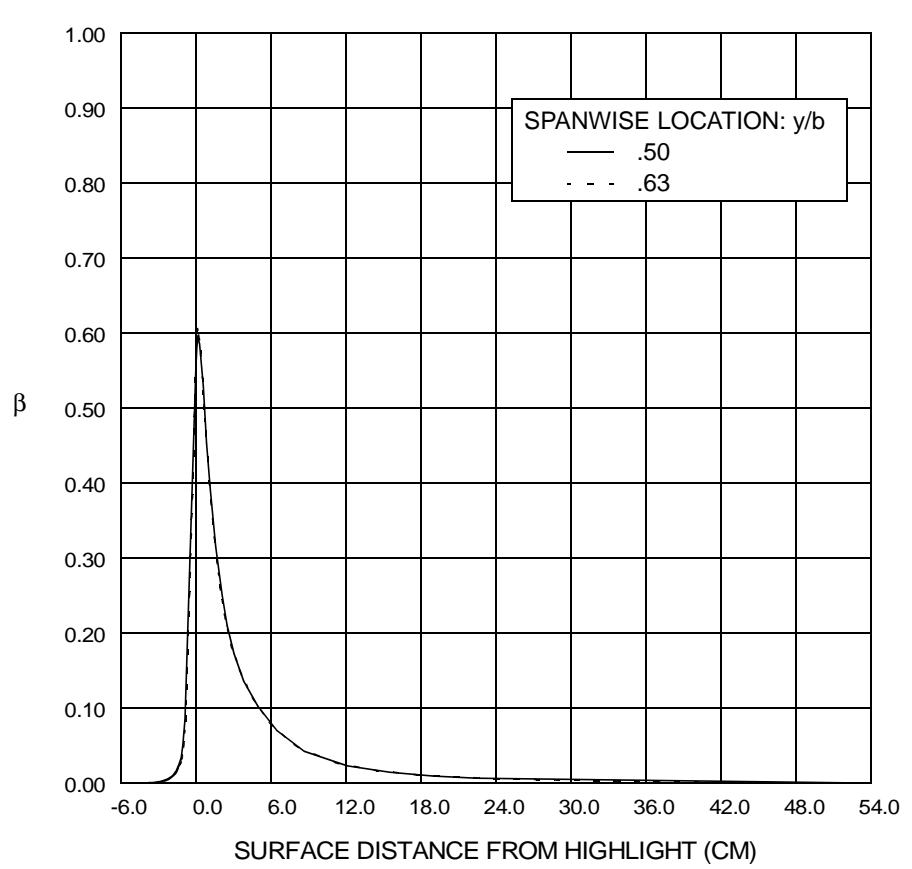

Lower Surface $\longrightarrow$

Figure 45: Theoretical collection efficiency for the full scale horizontal tail for angle-of-attack, $6^{\circ}$. Icing Conditions: airspeed, $75 \mathrm{~m} / \mathrm{s}$; static temperature, $-9.3^{\circ} \mathrm{C}$; static pressure, $95840 \mathrm{~Pa}$; MVD, $21 \mu \mathrm{m}$.

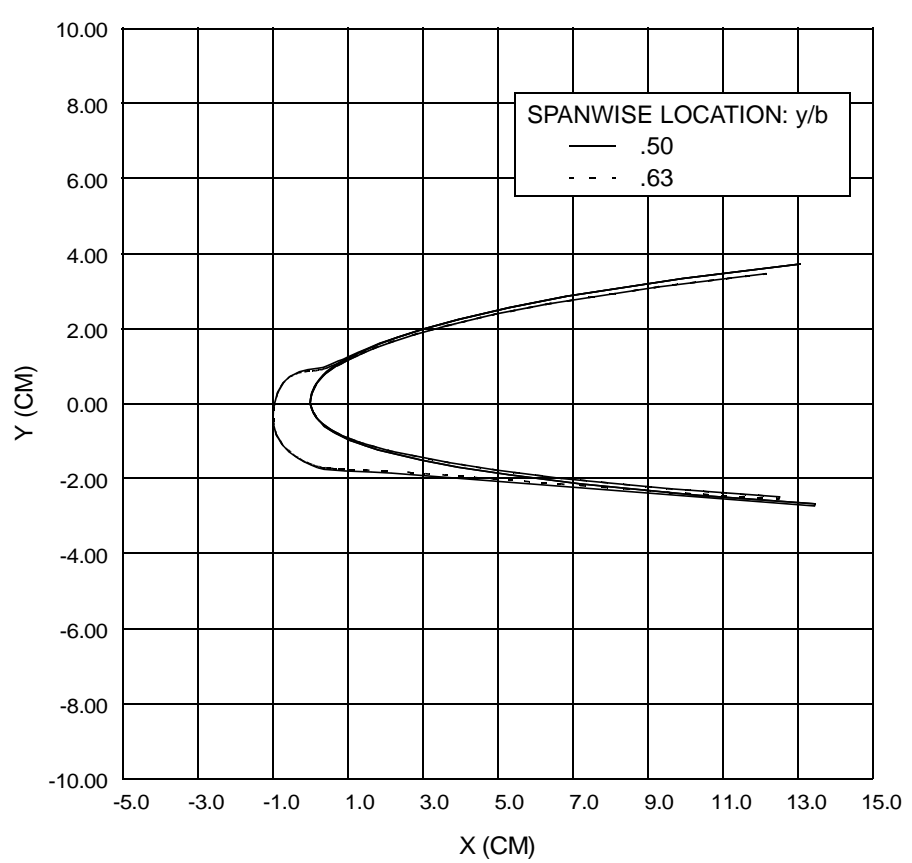

Figure 47: Theoretical ice shapes for the full scale horizontal tail for $6^{\circ}$ angle-of-attack. Icing conditions: airspeed, $75 \mathrm{~m} / \mathrm{s}$; icing time, 30 minutes; static temperature, $-29.9^{\circ} \mathrm{C}$; static pressure, $95840 \mathrm{~Pa}$; liquid water content, . $2 \mathrm{~g} / \mathrm{m}^{3}$; MVD, $21 \mu \mathrm{m}$. 


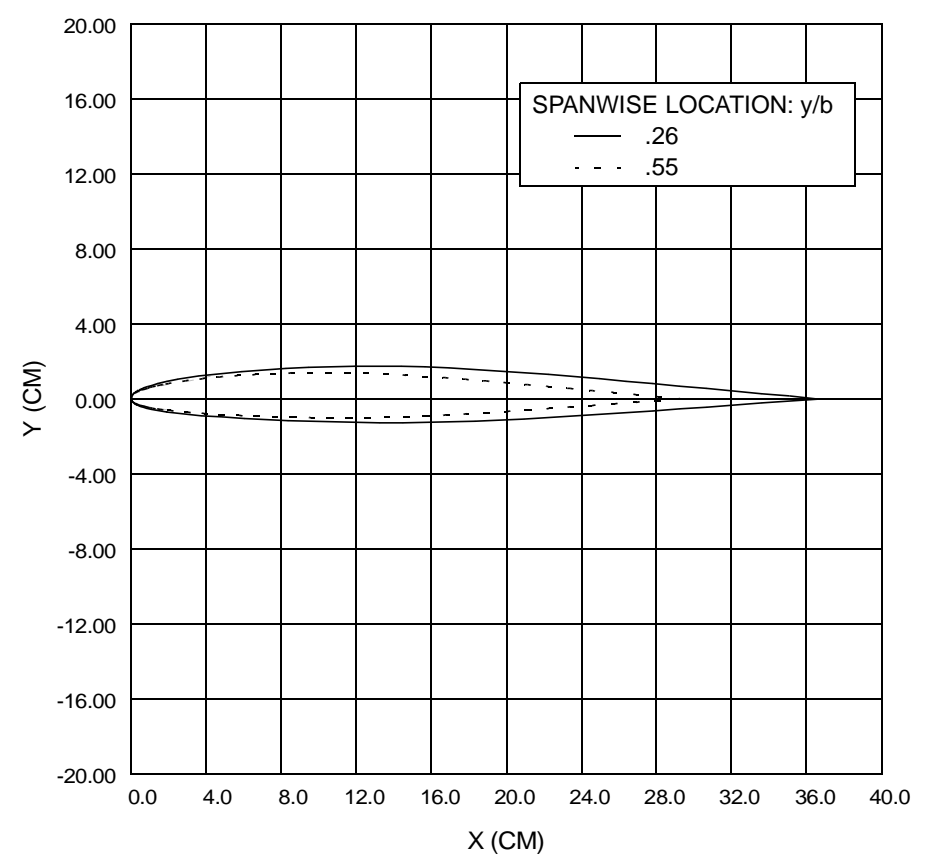

Figure 48: Wing profiles for the $25 \%$ scale horizontal tail.

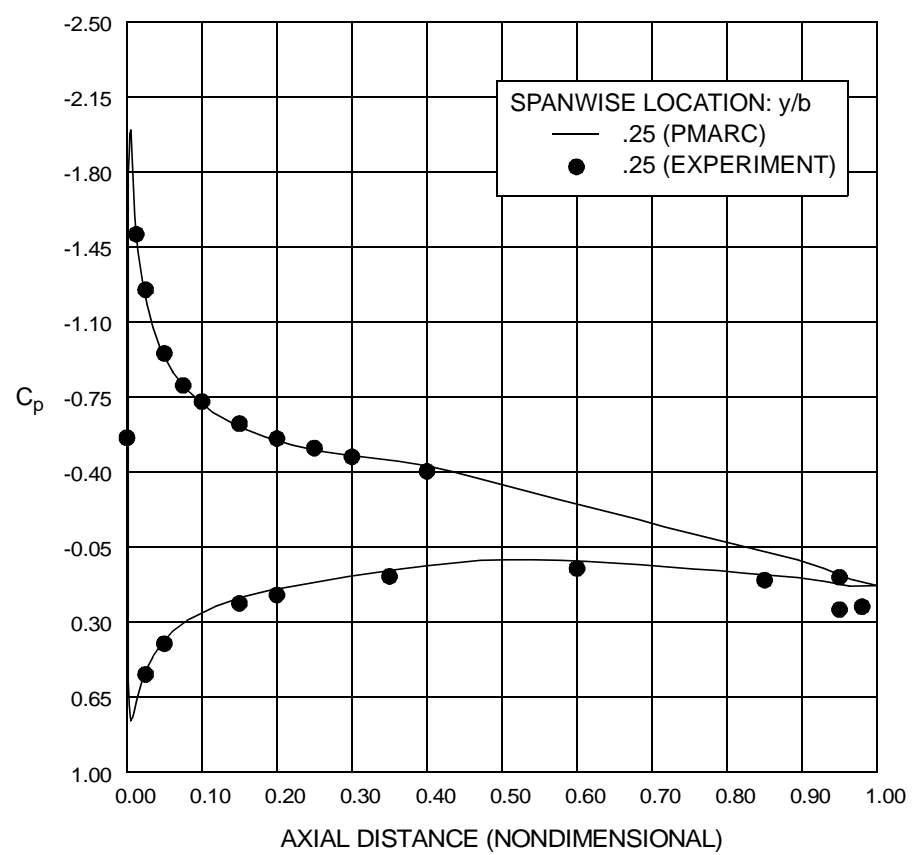

Figure 50: Experimental and analytical coefficient of pressure distribution for the $25 \%$ scale horizontal tail for angle-of-attack, $6^{\circ}$; airspeed, $75 \mathrm{~m} / \mathrm{s}$; static temperature, $7^{\circ} \mathrm{C}$; static pressure, $95840 \mathrm{~Pa}$.

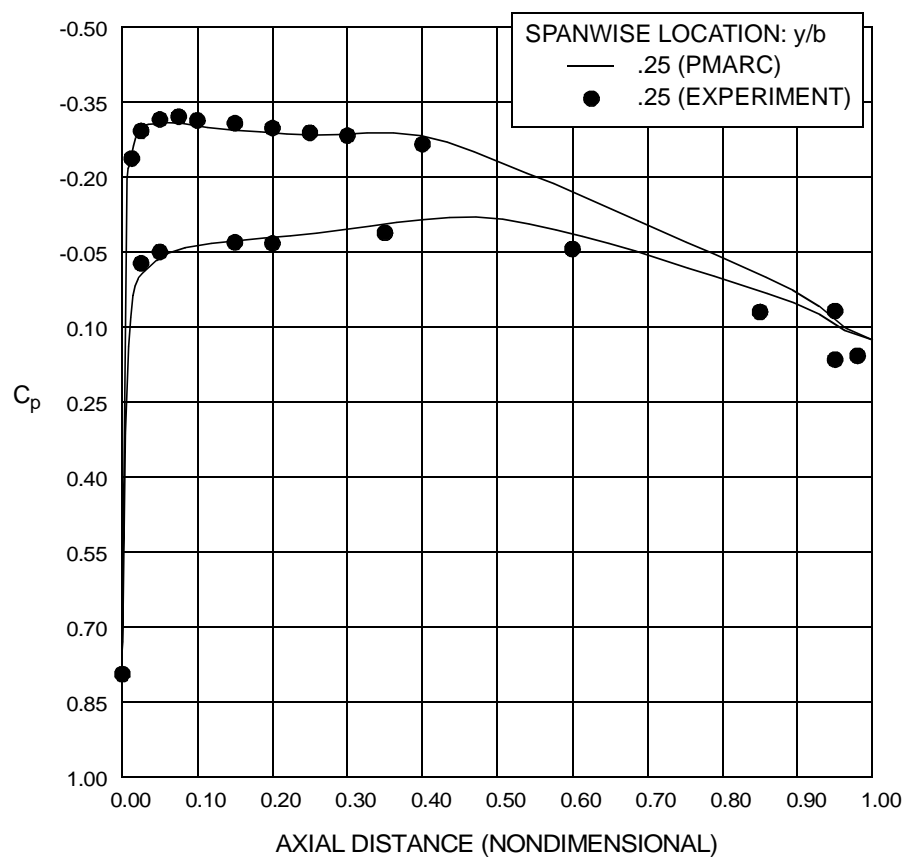

Figure 49: Experimental and analytical coefficient of pressure distribution for the $25 \%$ scale horizontal tail for angle-of-attack, $1^{\circ}$; airspeed, $75 \mathrm{~m} / \mathrm{s}$; static temperature, $7^{\circ} \mathrm{C}$; static pressure, $95840 \mathrm{~Pa}$.

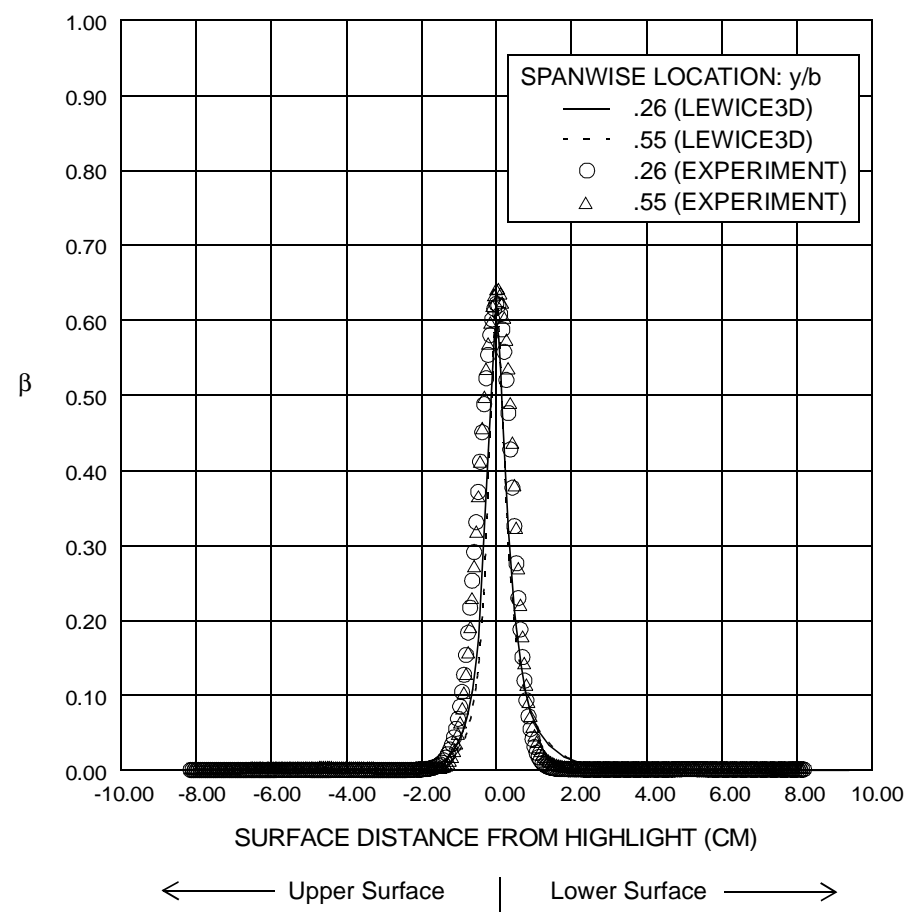

Figure 51: Experimental and analytical collection efficiency for the $25 \%$ scale horizontal tail for angleof-attack, $1^{\circ}$; airspeed, $75 \mathrm{~m} / \mathrm{s}$; static temperature, $7^{\circ} \mathrm{C}$; static pressure, $95840 \mathrm{~Pa}, \mathrm{MVD}, 11 \mu \mathrm{m}$. 


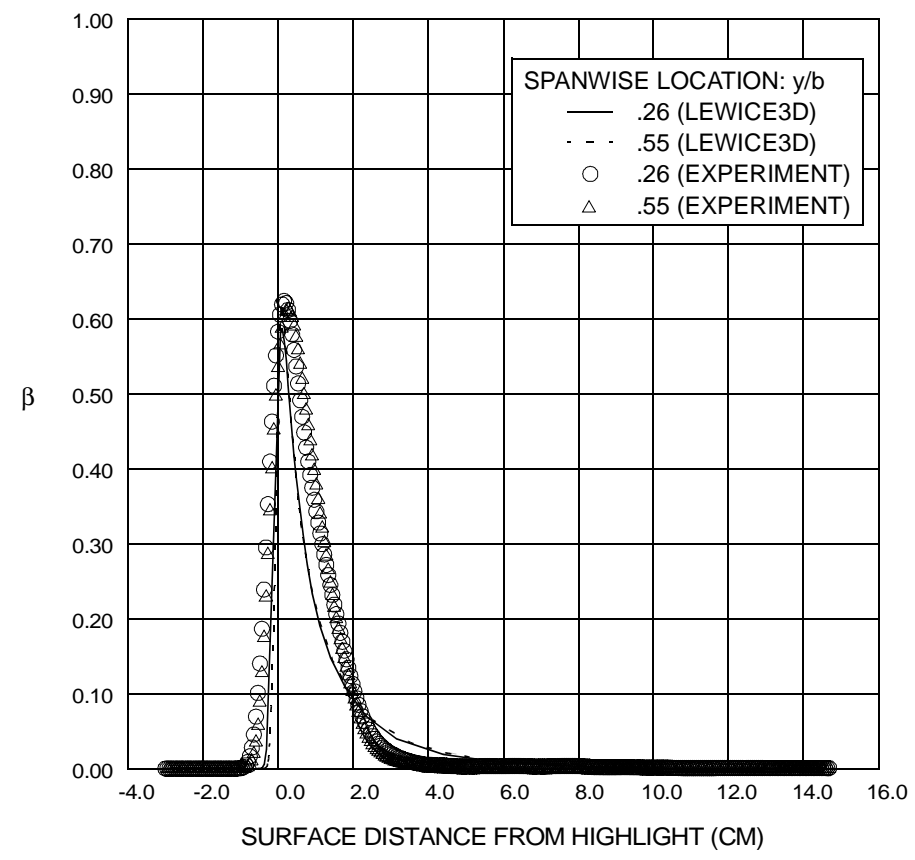

$\leftarrow$ Upper Surface $\quad \mid$ Lower Surface $\longrightarrow$

Figure 52: Experimental and analytical collection efficiency for the $25 \%$ scale horizontal tail for angleof-attack, $6^{\circ}$; airspeed, $75 \mathrm{~m} / \mathrm{s}$; static temperature, $7^{\circ} \mathrm{C}$; static pressure, $95840 \mathrm{~Pa}, \mathrm{MVD}, 11 \mu \mathrm{m}$.

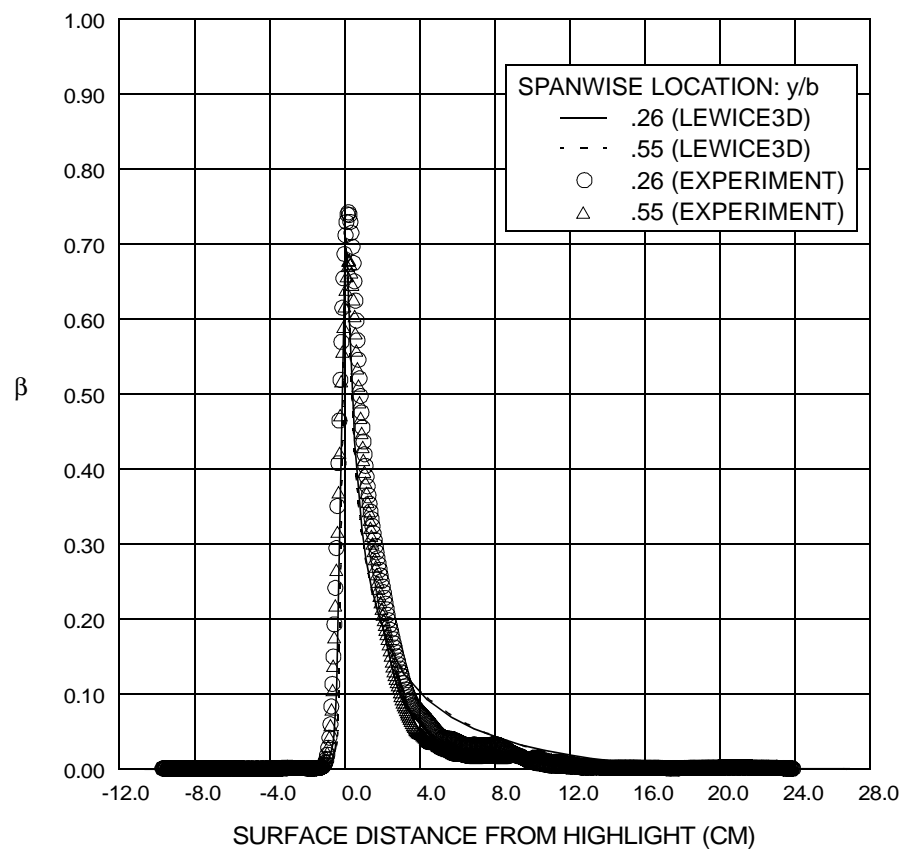

$\longleftrightarrow$ Upper Surface $\quad$ Lower Surface $\longrightarrow$

Figure 54: Experimental and analytical collection efficiency for the $25 \%$ scale horizontal tail for angleof-attack, $6^{\circ}$; airspeed, $75 \mathrm{~m} / \mathrm{s}$; static temperature, $7^{\circ} \mathrm{C}$; static pressure, $95840 \mathrm{~Pa}, \mathrm{MVD}, 21 \mu \mathrm{m}$.

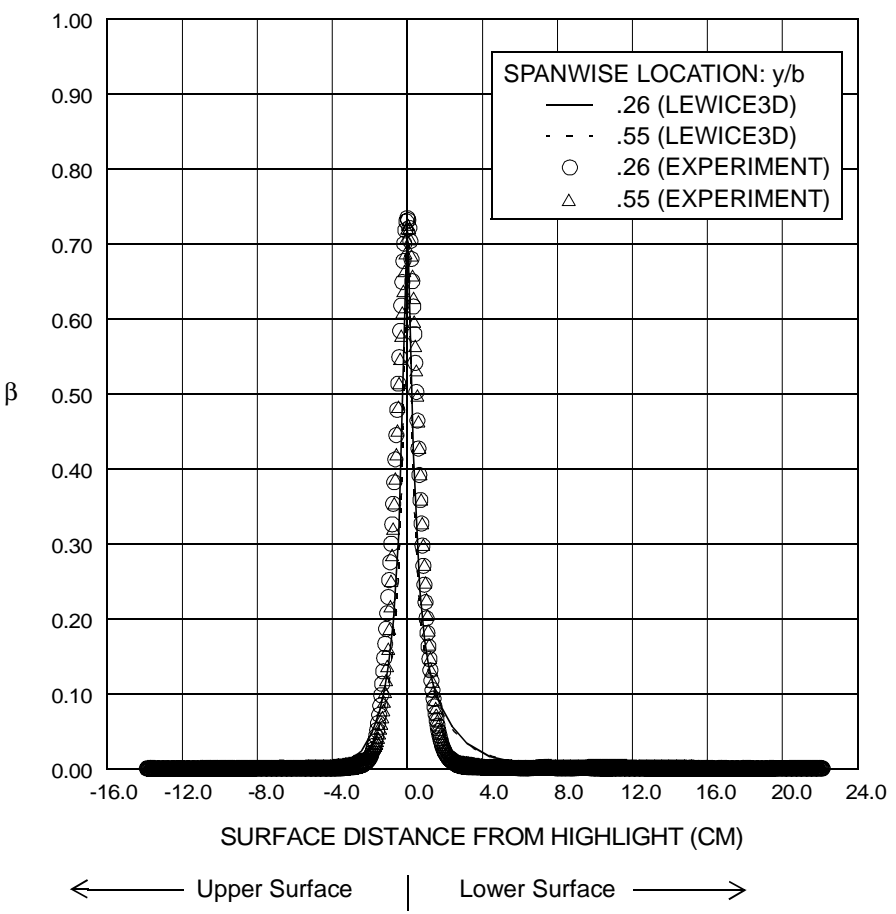

Figure 53: Experimental and analytical collection efficiency for the $25 \%$ scale horizontal tail for angleof-attack, $1^{\circ}$; airspeed, $75 \mathrm{~m} / \mathrm{s}$; static temperature, $7^{\circ} \mathrm{C}$; static pressure, $95840 \mathrm{~Pa}, \mathrm{MVD}, 21 \mu \mathrm{m}$.

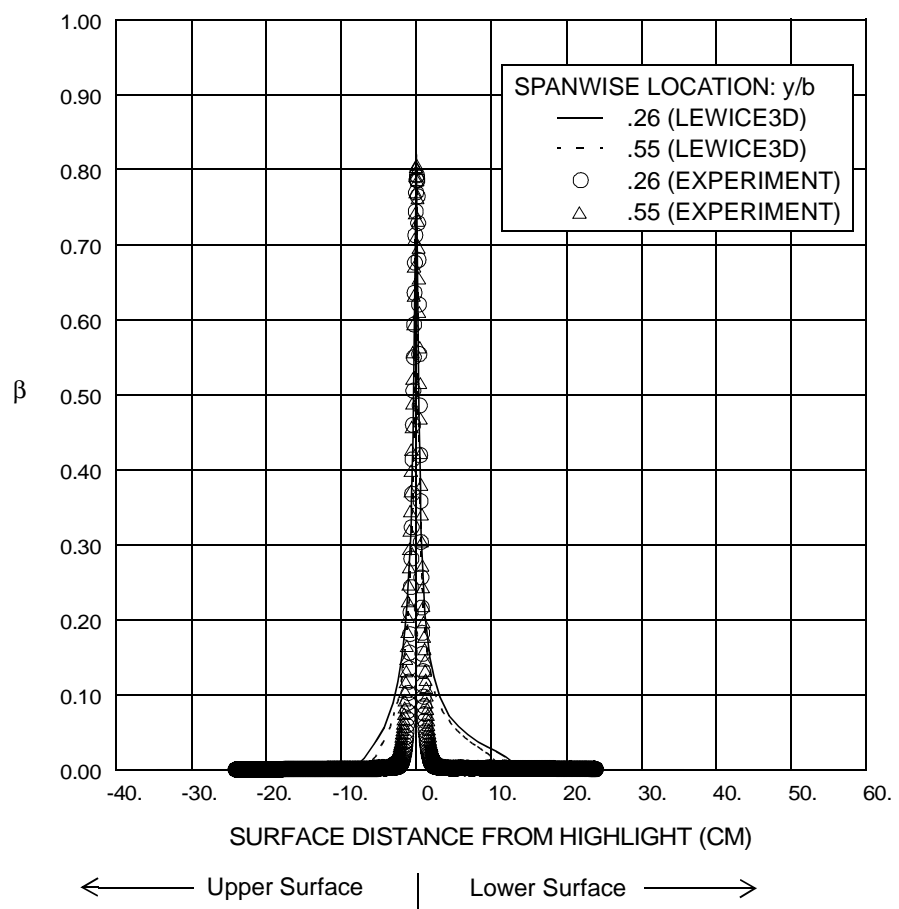

Figure 55: Experimental and analytical collection efficiency for the $25 \%$ scale horizontal tail for angleof-attack, $1^{\circ}$; airspeed, $75 \mathrm{~m} / \mathrm{s}$; static temperature, $7^{\circ} \mathrm{C}$; static pressure, $95840 \mathrm{~Pa}, \mathrm{MVD}, 92 \mu \mathrm{m}$. 


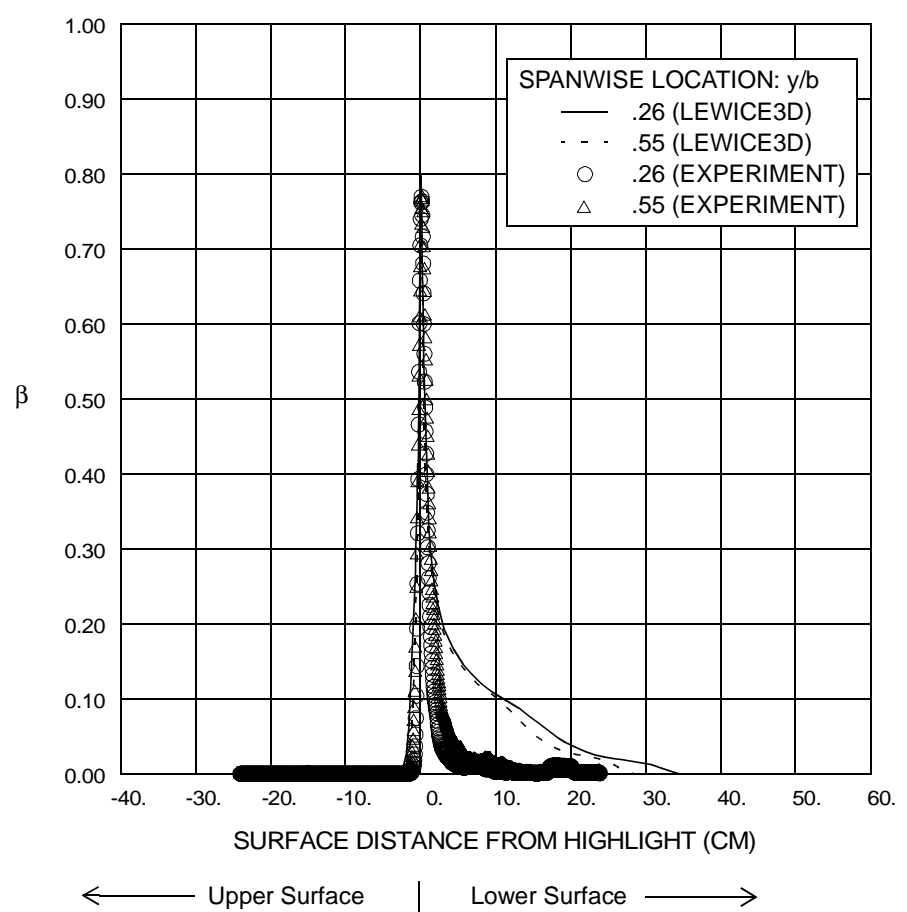

Figure 56: Experimental and analytical collection efficiency for the $25 \%$ scale horizontal tail for angleof-attack, $6^{\circ}$; airspeed, $75 \mathrm{~m} / \mathrm{s}$; static temperature, $7^{\circ} \mathrm{C}$; static pressure, $95840 \mathrm{~Pa}, \mathrm{MVD}, 92 \mu \mathrm{m}$.

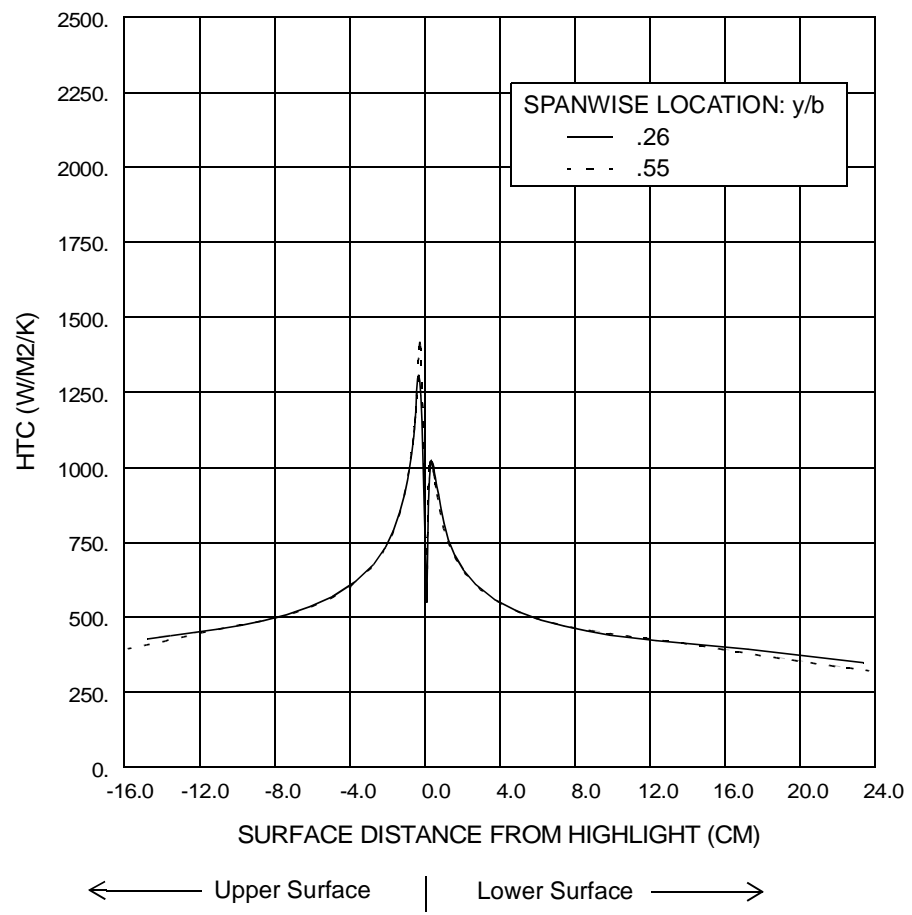

Figure 58: Theoretical heat transfer coefficient distribution for the $25 \%$ scale horizontal tail for angle-ofattack, $1^{\circ}$. Icing Conditions: airspeed, $75 \mathrm{~m} / \mathrm{s}$; static temperature, $-9.3^{\circ} \mathrm{C}$; static pressure, 95840 $\mathrm{Pa}$.

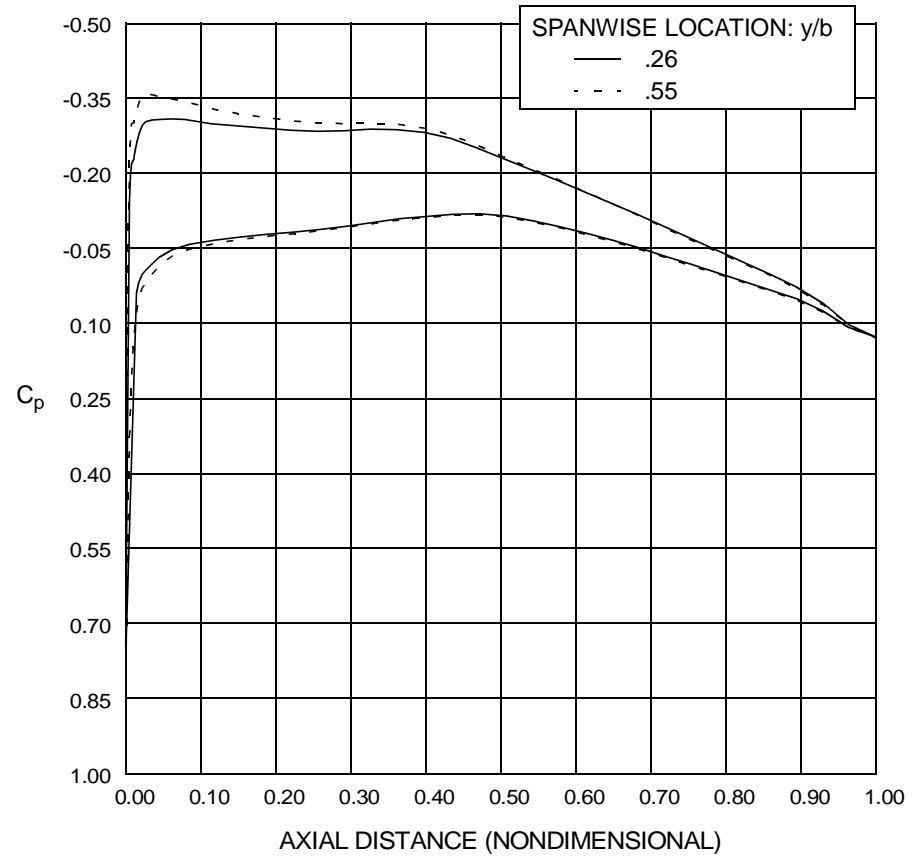

Figure 57: Theoretical coefficient of pressure distribution for the $25 \%$ scale horizontal tail for angle-ofattack, $1^{\circ}$. Icing Conditions: airspeed, $75 \mathrm{~m} / \mathrm{s}$; static temperature, $-9.3^{\circ} \mathrm{C}$; static pressure, 95840 $\mathrm{Pa}$.

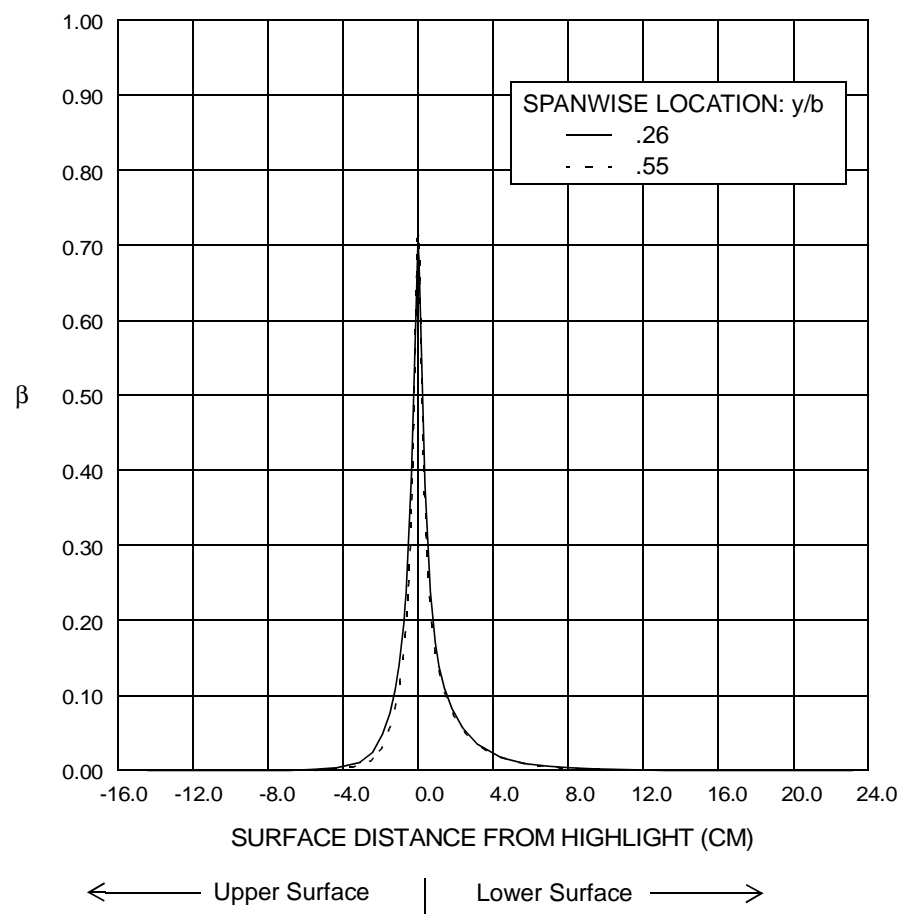

Figure 59: Theoretical collection efficiency for the 25\% scale horizontal tail for angle-of-attack, $1^{\circ}$. Icing Conditions: airspeed, $75 \mathrm{~m} / \mathrm{s}$; static temperature, $-9.3^{\circ} \mathrm{C}$; static pressure, $95840 \mathrm{~Pa}$; MVD, $21 \mu \mathrm{m}$. 


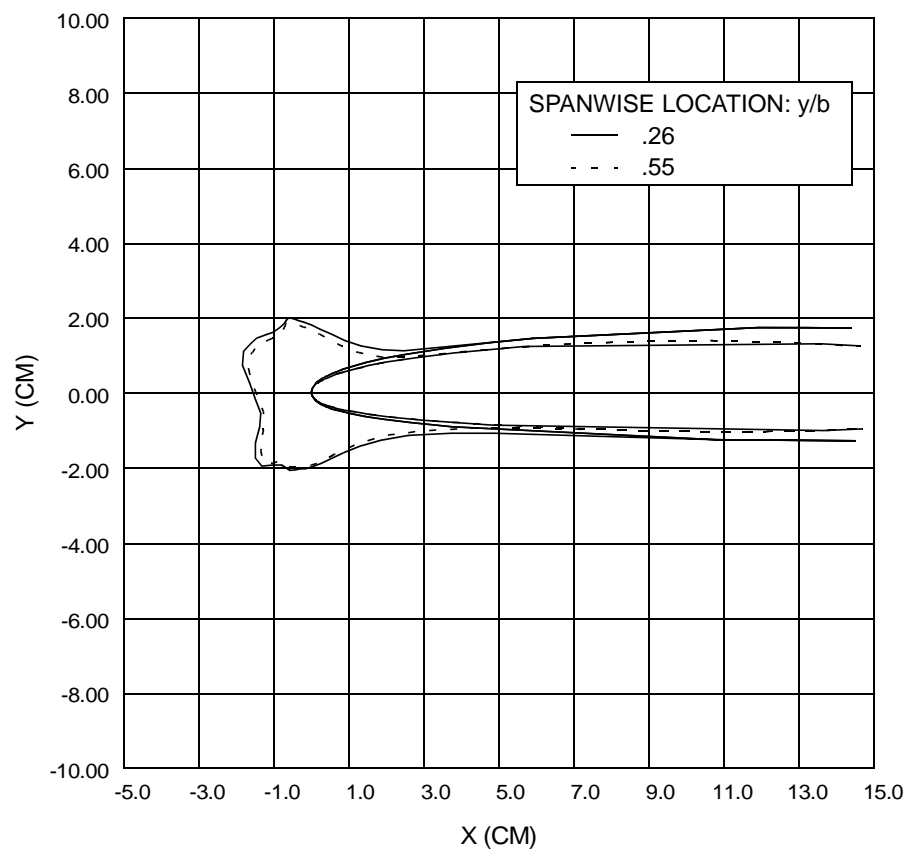

Figure 60: Theoretical ice shapes for the 25\% scale horizontal tail for $1^{\circ}$ angle-of-attack. Icing conditions: airspeed, $75 \mathrm{~m} / \mathrm{s}$; icing time, 30 minutes; static temperature, $-9.3^{\circ} \mathrm{C}$; static pressure, $95840 \mathrm{~Pa}$; liquid water content, .695 g/m³ $\mathrm{MVD}, 21 \mu \mathrm{m}$.

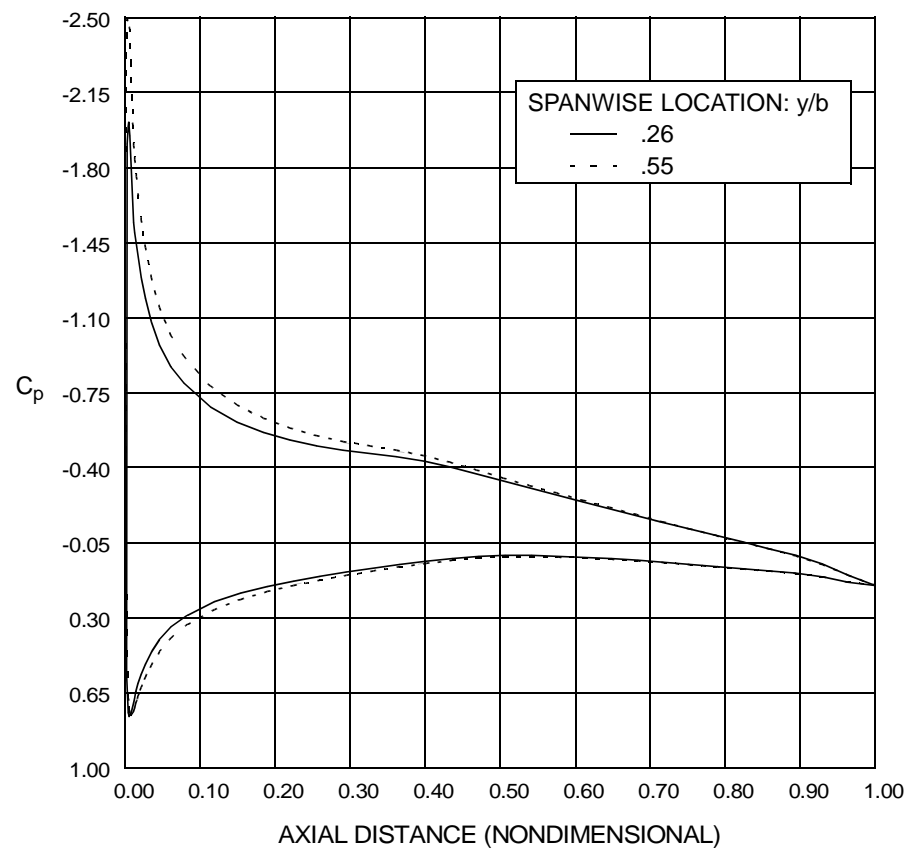

Figure 62: Theoretical coefficient of pressure distribution for the $25 \%$ scale horizontal tail for angle-ofattack, $6^{\circ}$. Icing Conditions: airspeed, $75 \mathrm{~m} / \mathrm{s}$; static temperature, $-9.3^{\circ} \mathrm{C}$; static pressure, 95840 $\mathrm{Pa}$.

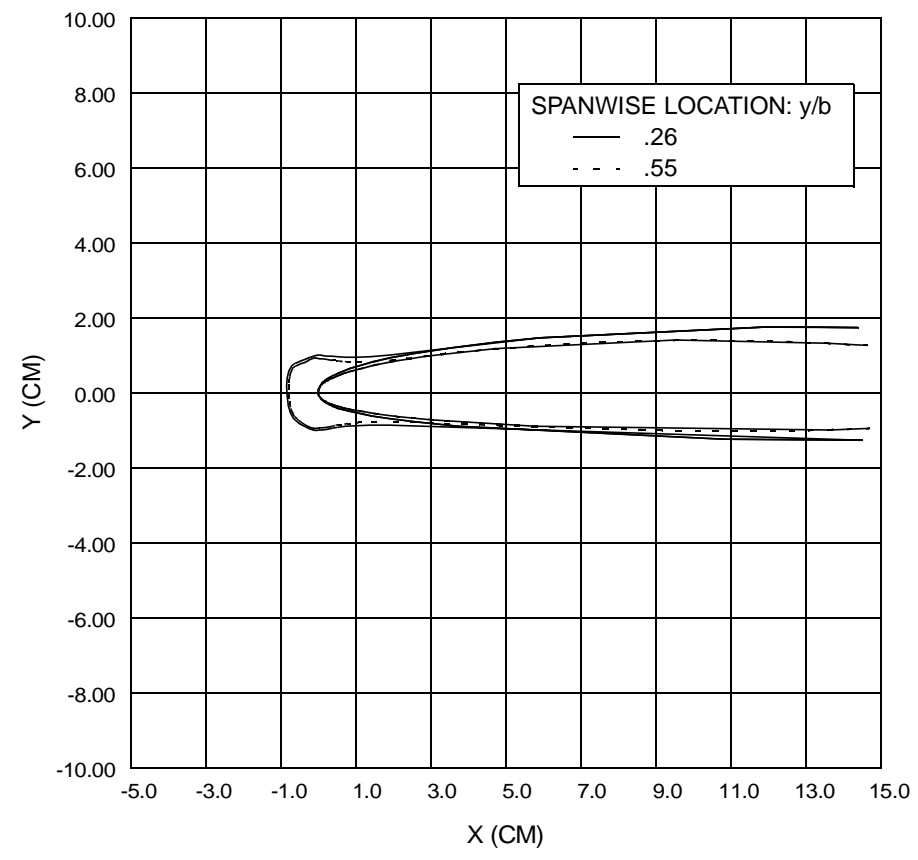

Figure 61: Theoretical ice shapes for the 25\% scale horizontal tail for $1^{\circ}$ angle-of-attack. Icing conditions: airspeed, $75 \mathrm{~m} / \mathrm{s}$; icing time, 30 minutes; static temperature, $-29.9^{\circ} \mathrm{C}$; static pressure, $95840 \mathrm{~Pa}$; liquid water content, $.2 \mathrm{~g} / \mathrm{m}^{3}$; MVD, $21 \mu \mathrm{m}$.

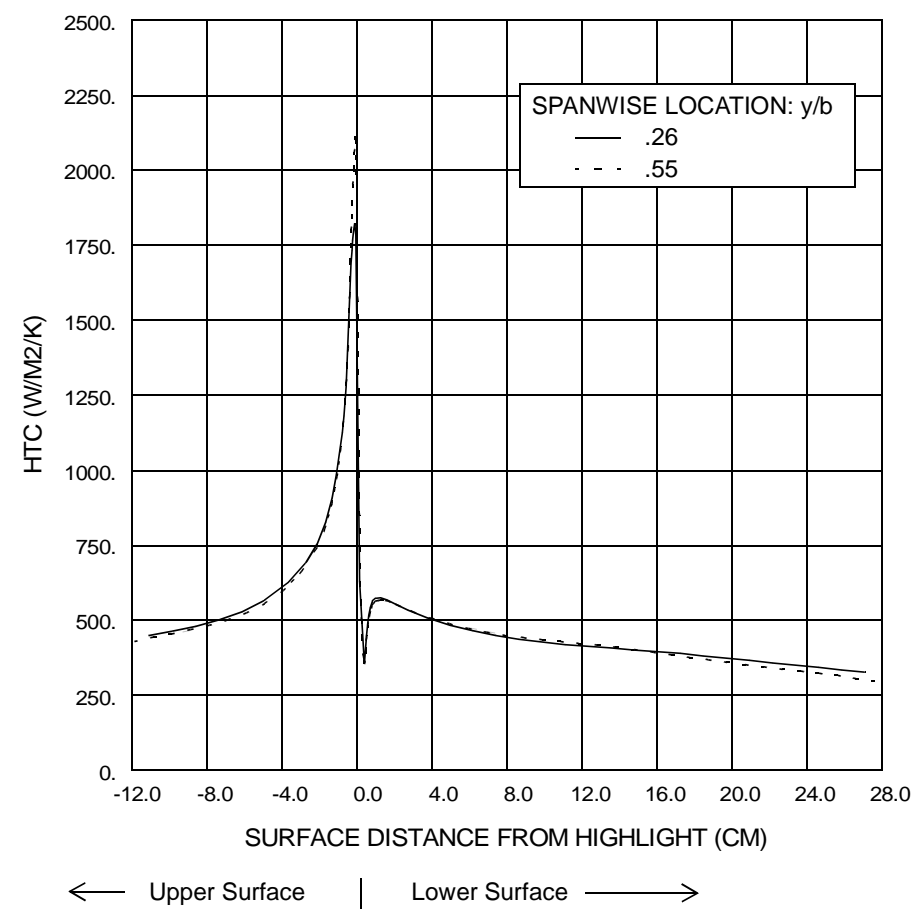

Figure 63: Theoretical heat transfer coefficient distribution for the $25 \%$ scale horizontal tail for angle-ofattack, $6^{\circ}$. Icing Conditions: airspeed, $75 \mathrm{~m} / \mathrm{s}$; static temperature, $-9.3^{\circ} \mathrm{C}$; static pressure, 95840 $\mathrm{Pa}$. 


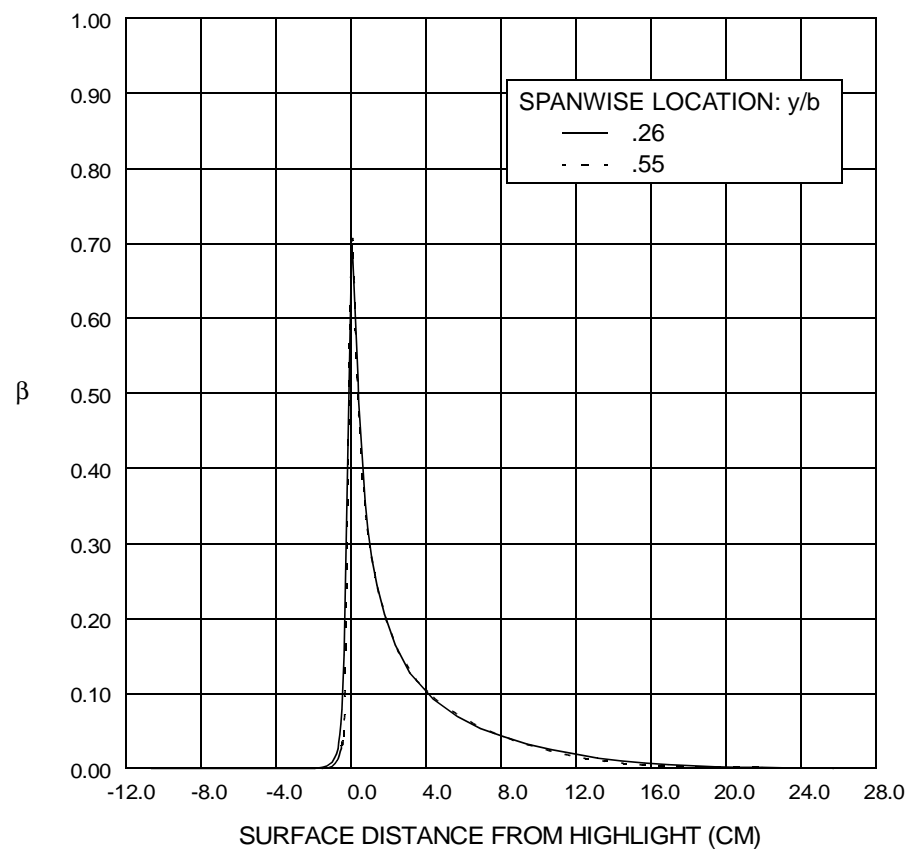

$\longleftrightarrow$ Upper Surface $\quad$ Lower Surface $\longrightarrow$

Figure 64: Theoretical collection efficiency for the 25\% scale horizontal tail for angle-of-attack, $6^{\circ}$. Icing Conditions: airspeed, $75 \mathrm{~m} / \mathrm{s}$; static temperature, $-9.3^{\circ} \mathrm{C}$; static pressure, $95840 \mathrm{~Pa}$; MVD, $21 \mu \mathrm{m}$.

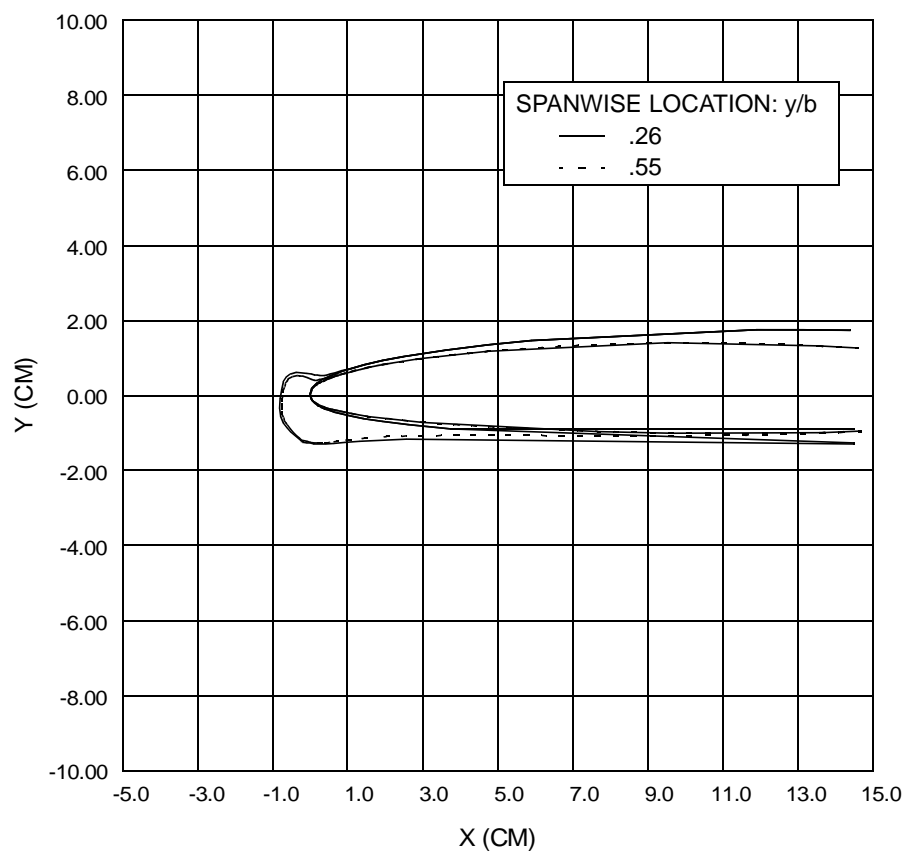

Figure 66: Theoretical ice shapes for the 25\% scale horizontal tail for $6^{\circ}$ angle-of-attack. Icing conditions: airspeed, $75 \mathrm{~m} / \mathrm{s}$; icing time, 30 minutes; static temperature, $-29.9^{\circ} \mathrm{C}$; static pressure, $95840 \mathrm{~Pa}$; liquid water content, . $2 \mathrm{~g} / \mathrm{m}^{3}$; MVD, $21 \mu \mathrm{m}$.

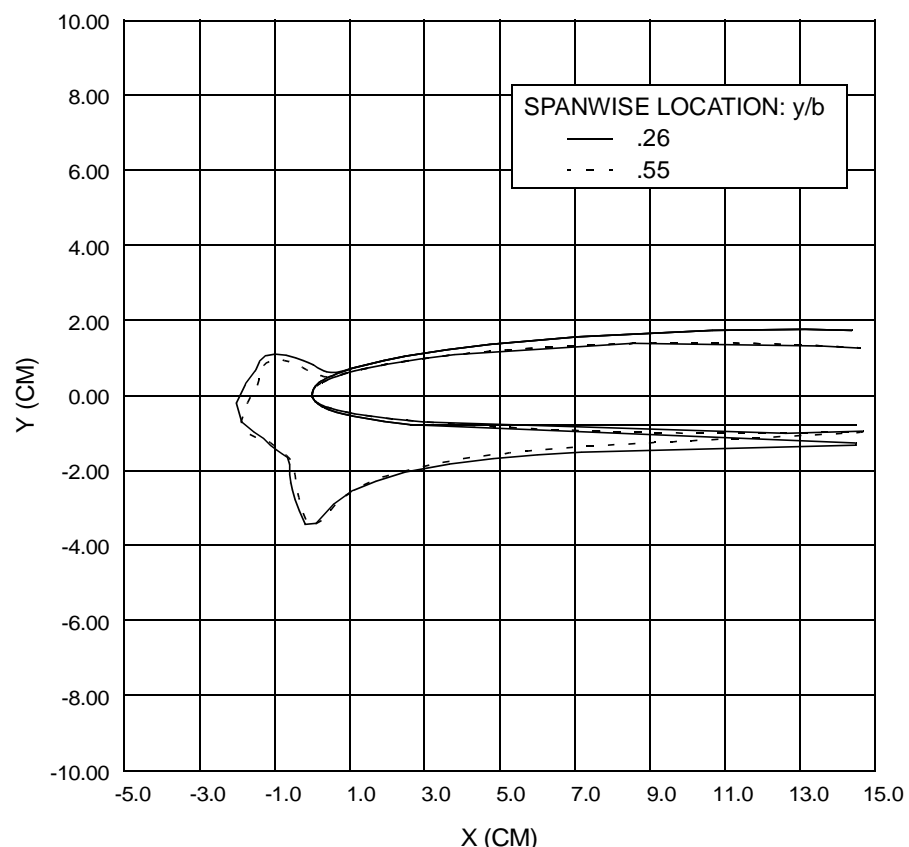

Figure 65: Theoretical ice shapes for the 25\% scale horizontal tail for $6^{\circ}$ angle-of-attack. Icing conditions: airspeed, $75 \mathrm{~m} / \mathrm{s}$; icing time, 30 minutes; static temperature, $-9.3^{\circ} \mathrm{C}$; static pressure, $95840 \mathrm{~Pa}$; liquid water content, .695 g/m³ $\mathrm{m}^{3}$ MVD, $21 \mu \mathrm{m}$. 


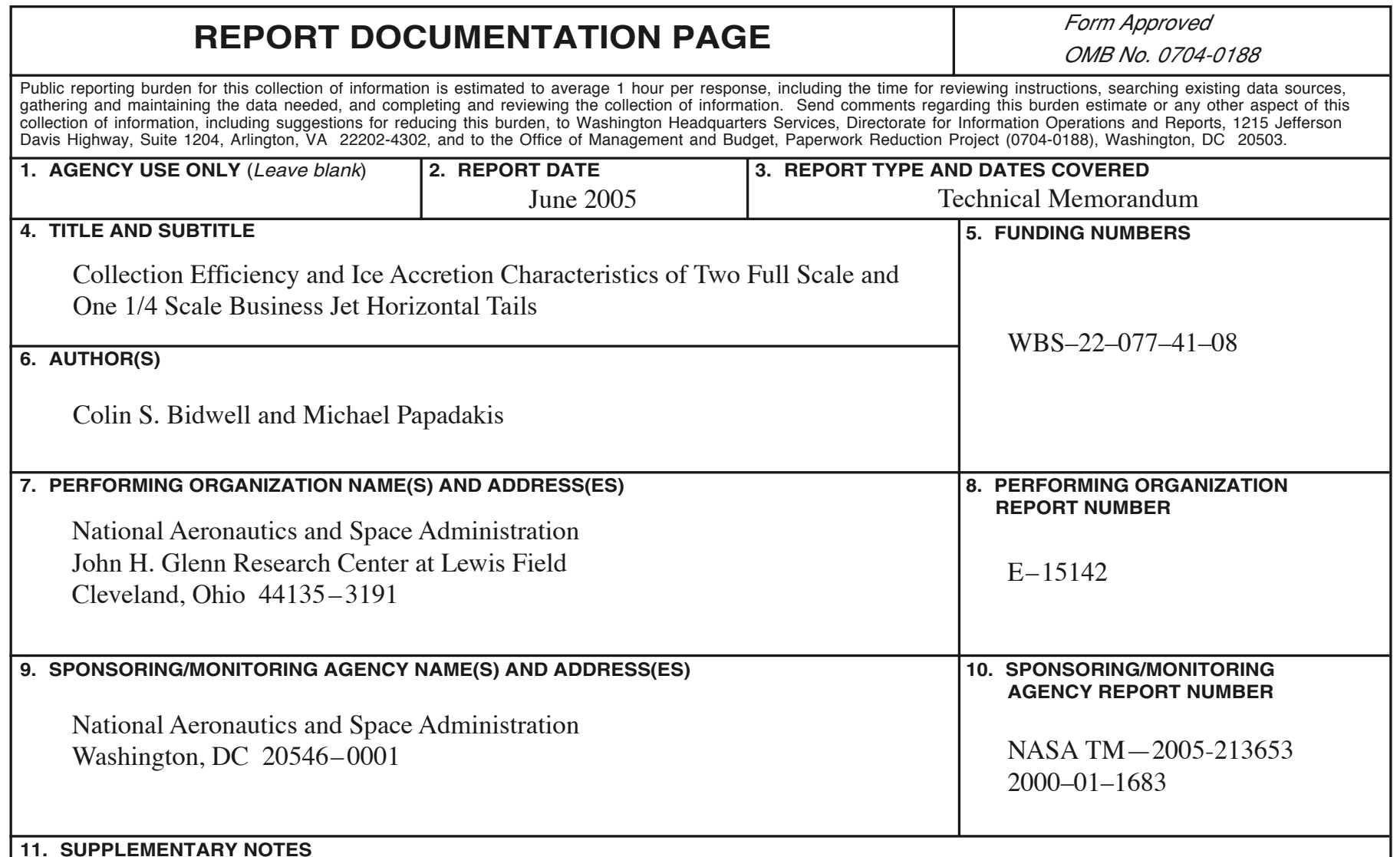

\section{SUPPLEMENTARY NOTES}

Prepared for the SAE General Aviation Technology Conference and Exposition sponsored by the Society of Automotive Engineers, Wichita, Kansas, May 9-11, 2000. Colin S. Bidwell, NASA Glenn Research Center; and Michael Papadakis, Wichita State University, 1845 Fairmount Street, Wichita, Kansas 67260. Responsible person, Colin S. Bidwell, organization code RTI, 216-433-3947.

\begin{tabular}{l|l}
\hline 12a. DISTRIBUTION/AVAILABILITY STATEMENT & 12b. DISTRIBUTION CODE \\
Unclassified - Unlimited & \\
Subject Categories: 02, 03, and 04 & \\
Available electronically at http://gltrs.grc.nasa.gov & \\
This publication is available from the NASA Center for AeroSpace Information, 301-621-0390. &
\end{tabular}

\section{ABSTRACT (Maximum 200 words)}

Collection efficiency and ice accretion calculations have been made for a series of business jet horizontal tail configurations using a three-dimensional panel code, an adaptive grid code, and the NASA Glenn LEWICE3D grid based ice accretion code. The horizontal tail models included two full scale wing tips and a 25 percent scale model. Flow solutions for the horizontal tails were generated using the PMARC panel code. Grids used in the ice accretion calculations were generated using the adaptive grid code ICEGRID. The LEWICE3D grid based ice accretion program was used to calculate impingement efficiency and ice shapes. Ice shapes typifying rime and mixed icing conditions were generated for a 30 minute hold condition. All calculations were performed on an SGI Octane computer. The results have been compared to experimental flow and impingement data. In general, the calculated flow and collection efficiencies compared well with experiment, and the ice shapes appeared representative of the rime and mixed icing conditions for which they were calculated.

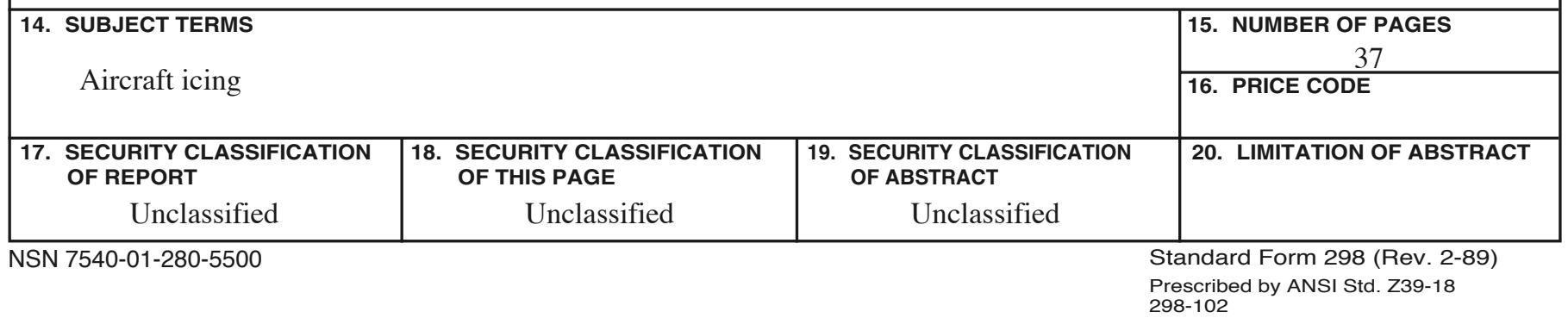



